Aus der Klinik für Psychosomatische Medizin und Psychotherapie

(Leitung: Prof. Dr. med. C. Herrmann-Lingen)

im Zentrum Psychosoziale Medizin

der Medizinischen Fakultät der Universität Göttingen

\title{
Charakterisierung von Punktmutationen in der DNA-Bindedomäne des humanen Transkriptionsfaktors STAT1
}

\author{
INAUGURAL-DISSERTATION \\ zur Erlangung des Doktorgrades \\ für Zahnheilkunde \\ der Medizinischen Fakultät der \\ Georg-August-Universität zu Göttingen
}

vorgelegt von

Jana Johanne Naegeler

aus

Göttingen

Göttingen 2014 
Dekan:

I. Berichterstatter:

II. Berichterstatter/in:

III. Berichterstatter/in:

Tag der mündlichen Prüfung:
Prof. Dr. rer. nat. H. K. Kroemer

Prof. Dr. med. Dr. phil. Dr. rer. nat. T. Meyer

Prof. Dr. rer. nat. D. Kube

Prof. Dr. med. dent. R. Mausberg

9.März. 2015 


\section{Inhaltsverzeichnis}

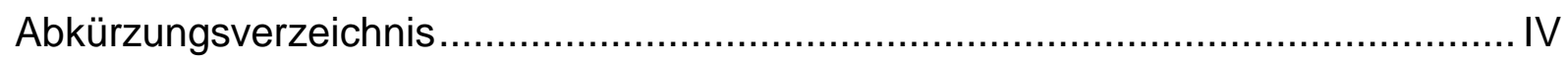

Proteinogene Aminosäuren ....................................................................... VIII

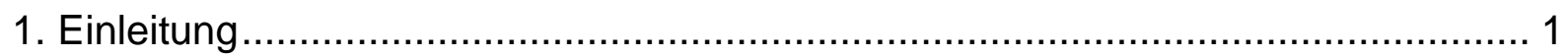

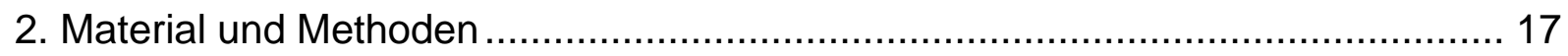

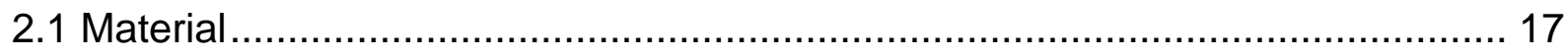

2.1.1 Humane Zelllinien .......................................................................... 17

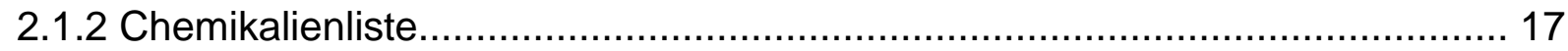

2.1.3 Radiochemikalien ................................................................................ 19

2.1.4 Puffer, Lösungen und Medien .............................................................. 19

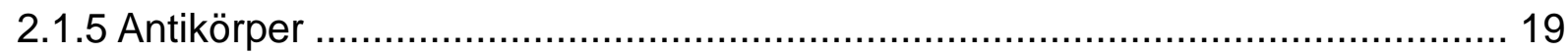

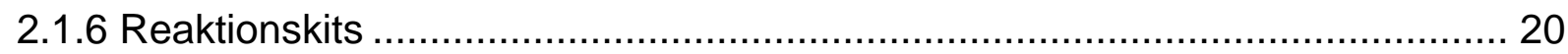

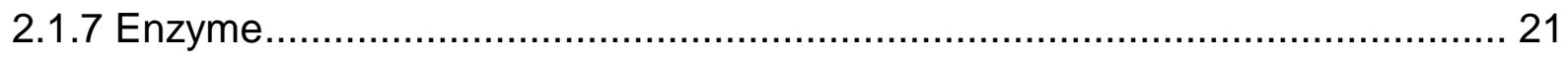

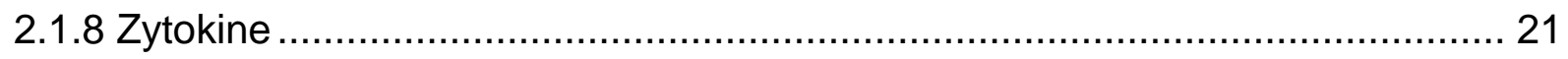

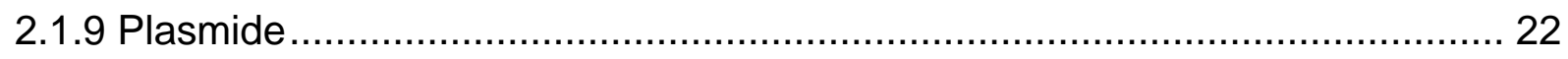

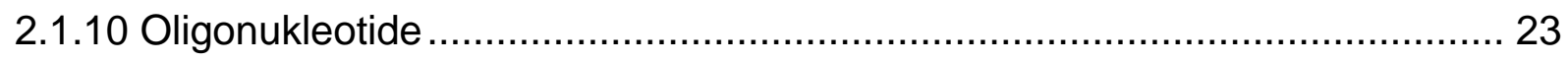

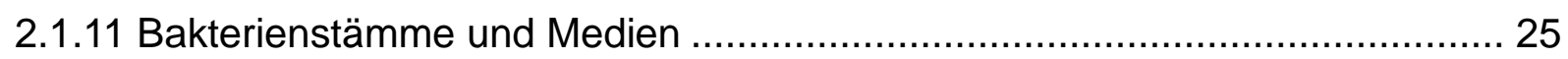

2.1.12 Geräte und Verbrauchsmaterialien ...................................................... 26

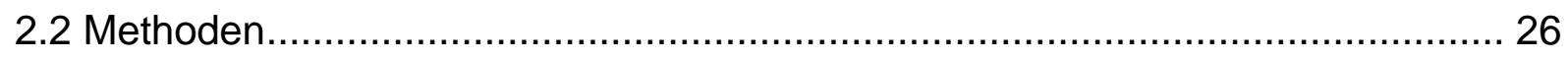

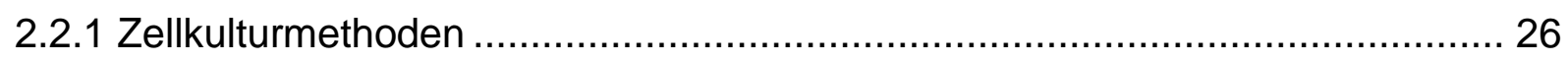

2.2.2 Transfektion von Säugerzellen .......................................................... 27

2.2.3 Behandlung von Zellen mit Zytokinen und Inhibitoren ................................ 28

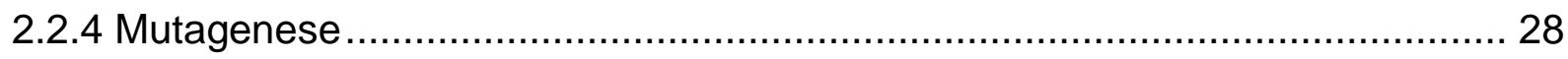

2.2.5 Transformation von Plasmid-DNA in kompetente Bakterien .......................... 28 
2.2.6 Isolation von Plasmid-DNA aus Bakterien ................................................ 29

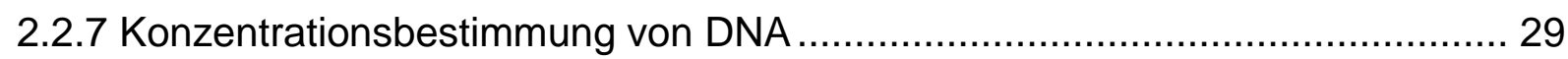

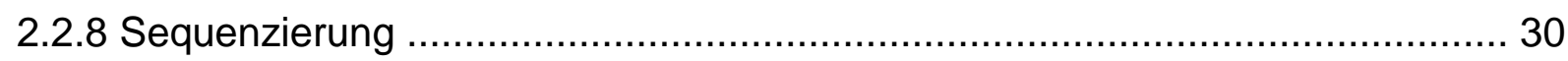

2.2.9 Herstellung von Zellextrakten ............................................................... 30

2.2.10 SDS-Polyacrylamid-Gelelektrophorese (SDS-PAGE) ................................. 31

2.2.11 Immunchemische Proteindetektion mittels Western Blot ............................... 31

2.2.12 Gelshift-Assays (Electrophoretic Mobility Shift Assay, EMSA) ….................. 32

2.2.14 Fluoreszenzmikroskopische Analyse ..................................................... 34

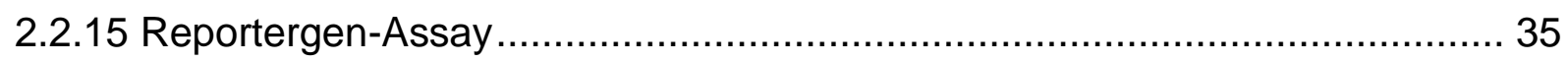

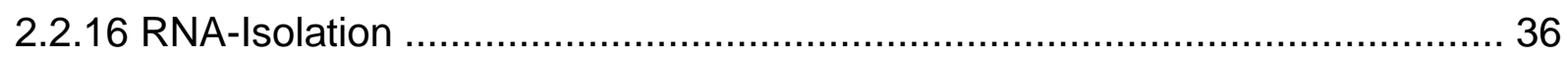

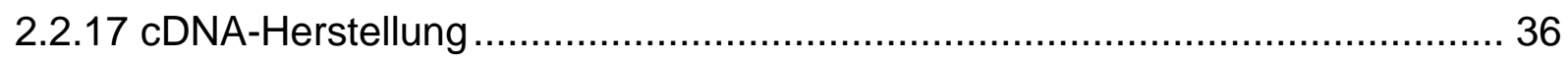

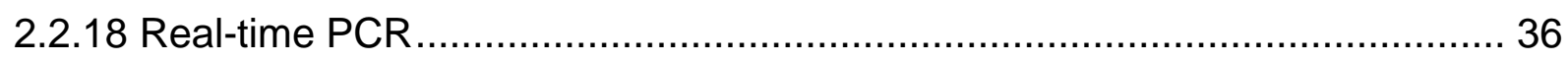

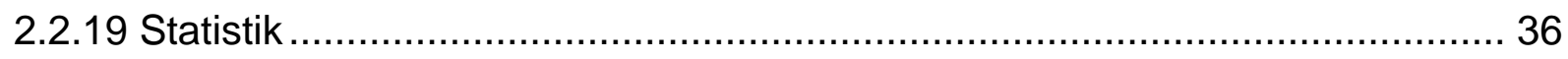

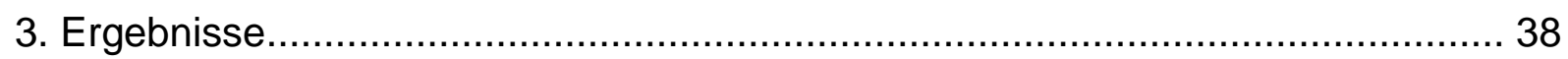

3.1 Die STAT1-Mutanten K359A, K361A und D367A zeigen ein vergleichbares Phosphorylierungsniveau wie das Wildtyp-Molekül ................................................ 39

3.2 Unauffällige Kinetik der IFNy-induzierten Kernakkumulation der drei

Punktmutanten

3.3 Die drei für diese Arbeit generierten Mutanten weisen eine normale

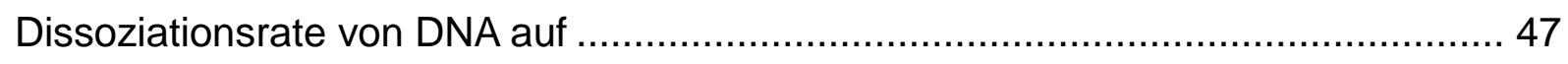

3.4. STAT1-K359A, -K361A und -D367A zeigen eine normale kooperative DNA-

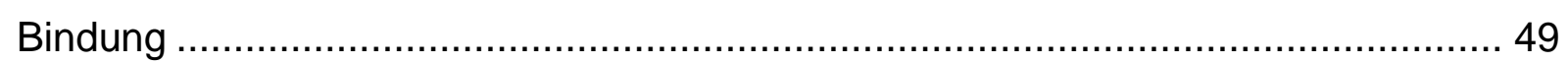

3.5. Alle Punktmutanten zeigen im Gelshift-Experiment eine regelrechte DNA-

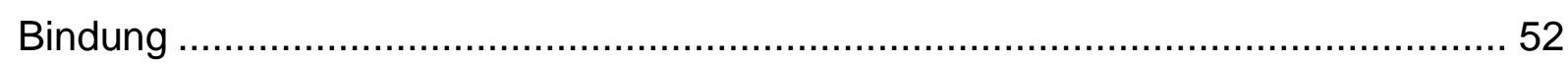

3.6 Die Mutanten dieser Arbeit haben eine mit dem STAT1-WT vergleichbare Affinität zur DNA. 55 
3.7 Es besteht eine vergleichbare Reportergen-Aktivität zwischen dem STAT1-WT sowie den Mutanten

3.8 Die generierten Punktmutanten weisen in der Expression bekannter STAT1Zielgene keine signifikanten Unterschiede zum STAT1-WT auf 58

4. Diskussion 60

5. Zusammenfassung 67

5.1 Summary 68

6. Literaturverzeichnis. 69 


\section{Abkürzungsverzeichnis}

\begin{tabular}{|c|c|}
\hline APS & Ammoniumperoxidsulfat \\
\hline AS & Aminosäure \\
\hline$\beta$-Gal & $\beta$-Galaktosidase \\
\hline bp & Basenpaare \\
\hline $\mathrm{Bq}$ & Becquerel \\
\hline BSA & bovines Serumalbumin \\
\hline c & centi \\
\hline${ }^{\circ} \mathrm{C}$ & Grad Celsius \\
\hline CBP & CREB-bindendes Protein \\
\hline CCD & Coiled-coil-Domäne \\
\hline cDNA & komplementäre DNA \\
\hline $\mathrm{CO}_{2}$ & Kohlenstoffdioxid \\
\hline CREB & engl.: cAMP response element-binding protein \\
\hline $\mathrm{Da}$ & Dalton \\
\hline DBD & DNA-Bindedomäne \\
\hline DMEM & Dulbecco's modifiziertes Eagle-Medium \\
\hline DMSO & Dimethylsulfoxid \\
\hline DNA & Desoxyribonukleinsäure \\
\hline dNTP & Desoxynukleosidtriphosphat \\
\hline DTT & Dithiothreitol \\
\hline EDTA & Ethylendiamin-N,N,N',N'-Tetraessigsäure \\
\hline EGTA & Ethylenglycol-bis(2-aminoethylether)-N,N,N',N'-tetraessigsäure \\
\hline EMSA & elektrophoretischer Mobilitäts-Shift-Assay \\
\hline FBS & fetales Kälberserum \\
\hline g & Erdbeschleunigung oder Gramm \\
\hline GAPDH & Glycerinaldehyd-3-phosphat-Dehydrogenase \\
\hline GAS & Gamma-aktivierte Sequenz \\
\hline GBP & Guanylat-bindendes Protein \\
\hline
\end{tabular}




\begin{tabular}{|c|c|}
\hline GDP & Guanosindiphosphat \\
\hline GFP & grün-fluoreszierendes Protein \\
\hline GTP & Guanosintriphosphat \\
\hline h & Stunde(n) \\
\hline Hepes & $\mathrm{N}-(2-$ Hydroxyethyl)-1-Piperazino-Ethansulfonsäure \\
\hline $\mathrm{H}_{2} \mathrm{O}$ & Wasser \\
\hline $\mathrm{H}_{2} \mathrm{O}_{2}$ & Wasserstoffperoxid \\
\hline IFN & Interferon \\
\hline IL & Interleukin \\
\hline IRF1 & IFN-regulierender Faktor 1 \\
\hline ISRE & engl.: interferon-stimulated response element \\
\hline JAK & Janus-Kinase \\
\hline $\mathrm{KCl}$ & Kaliumchlorid \\
\hline LB & Luria-Broth \\
\hline LD & Linker-Domäne \\
\hline $\mathrm{m}$ & milli oder Meter \\
\hline$\mu$ & mikro \\
\hline M & Molar \\
\hline $\mathrm{MgCl} 2$ & Magnesiumchlorid \\
\hline MgSO4 & Magnesiumsulfat \\
\hline $\mathrm{MHC}$ & Haupthistokompatibilitätskomplex \\
\hline MIG & engl.: monokine-induced by IFN \\
\hline $\min$ & Minute(n) \\
\hline$n$ & nano \\
\hline $\mathrm{NaCl}$ & Natriumchlorid \\
\hline $\mathrm{NaOH}$ & Natriumhydroxid \\
\hline Na3VO4 & Natrium-ortho-Vanadat \\
\hline ND & aminoterminale Domäne \\
\hline NF-kB & nukleärer Faktor-KappaB \\
\hline NLS & nukleäres Lokalisationssignal \\
\hline
\end{tabular}




\begin{tabular}{|c|c|}
\hline NPC & nukleärer Porenkomplex \\
\hline ONPG & Ortho-Nitrophenyl- $\beta$-D-Galactopyranosid \\
\hline PAGE & Polyacrylamid-Gelelektrophorese \\
\hline PBS & Phosphat-gepufferte Salzlösung \\
\hline PCR & Polymerase-Kettenreaktion \\
\hline PDB & Protein-Data-Bank \\
\hline PIAS & $\begin{array}{l}\text { Protein-Inhibitor von aktiviertem STAT } \\
\text { (engl.: protein inhibitor of activated STATs) }\end{array}$ \\
\hline PKR & Proteinkinase $\mathrm{R}$ \\
\hline Poly-dldC & Poly-Desoxyinosin-Desoxycytidyl-Säure \\
\hline pSTAT1 & STAT1-kodierendes pcDNA3.1-Plasmid \\
\hline pSTAT1-GFP & STAT1-kodierendes pEGFP-N1-Plasmid \\
\hline PVDF & Polyvinylidenfluorid \\
\hline RNA & Ribonukleinsäure \\
\hline rpm & Umdrehungen pro Minute \\
\hline RT & Raumtemperatur \\
\hline RT-PCR & real-time PCR \\
\hline SDS & Natriumlaurylsulfat \\
\hline $\mathrm{sec}$ & Sekunde(n) \\
\hline $\mathrm{SH} 1$ & Src-Homologie-1 \\
\hline $\mathrm{SH} 2$ & Src-Homologie-2 \\
\hline STAT & Signaltransduktor und Aktivator der Transkription \\
\hline T-Zelle & T-Lymphozyt \\
\hline TAD & Transaktivierungsdomäne \\
\hline TBE & Tris-Borsäure-EDTA \\
\hline TBS-T & Tris-gepufferte Salzlösung mit 0,05\% Tween \\
\hline TC-PTP & T-Zell-Protein-Tyrosin-Phosphatase \\
\hline TEMED & $\mathrm{N}, \mathrm{N}, \mathrm{N}^{*}, \mathrm{~N}^{\star},-$ Tetramethylethylendiamin \\
\hline TH1-Zelle & T-Helferzelle Typ 1 \\
\hline TH2-Zelle & T-Helferzelle Typ 2 \\
\hline
\end{tabular}




\begin{tabular}{l|l} 
Tris & Tris-(Hydroxylmethyl)-Aminomethan \\
\hline TYK & Tyrosin-Kinase \\
\hline UV & ultraviolett \\
\hline V & Volumen \\
\hline V & Volt \\
\hline WT & Wildtyp
\end{tabular}




\section{Proteinogene Aminosäuren}

\begin{tabular}{l|l|l} 
Aminosäure & Abkürzung & Buchstabencode \\
\hline Alanin & Ala & A \\
\hline Cystein & Cys & C \\
\hline Asparaginsäure & Asp & D \\
\hline Glutaminsäure & Glu & E \\
\hline Phenylalanin & Phe & F \\
\hline Glycin & Gly & G \\
\hline Histidin & His & H \\
\hline Isoleucin & Ile & I \\
\hline Lysin & Lys & K \\
\hline Leucin & Leu & L \\
\hline Methionin & Met & M \\
\hline Asparagin & Asn & N \\
\hline Prolin & Pro & P \\
\hline Glutamin & Gln & Q \\
\hline Arginin & Arg & R \\
\hline Serin & Ser & S \\
\hline Threonin & Thr & T \\
\hline Valin & Val & V \\
\hline Tryptophan & Trp & W \\
\hline Tyrosin & Tyr & Y
\end{tabular}




\section{Einleitung}

Eukaryontische Zellen nutzen vielfältige Signaltransduktionen, die der interzellulären Kommunikation und der Aufrechterhaltung der zelleigenen Homöostase dienen. Die Signaltransduktion ist eine komplexe Reaktionsfolge als Antwort auf eine auf äußere Reize hin erfolgte Sezernierung extrazellulärer Botenstoffe. Viele Botenstoffe sind in der Lage, an spezifische Rezeptorproteine zu binden und somit eine Signalkaskade sowie eine darauffolgende zielgerichtete Zellantwort auszulösen. Der JAK-STATSignalweg ist ein besonders bedeutender und daher gut studierter signalabhängiger Transkriptionsweg, dessen Fehlregulation zu menschlichen Krankheiten beitragen kann. Die Abkürzung JAK steht für sogenannte Janus-Kinasen, wobei die Bezeichnung auf den doppelköpfigen römischen Gott anspielt, da diese Kinasen zwei Proteindomänen besitzen, die einander sehr ähnlich sind, sich jedoch nur eine als funktional erweist.

STAT-Proteine (Signal Transducers and Activators of Transcription) sind Signaltransduktoren und Aktivatoren der Transkription. Durch die Aktivierung der rezeptorgebundenen Janus-Kinasen und deren Phosphorylierung untereinander als Antwort auf eine Zytokinstimulation kommt es zur Phosphorylierung der STAT-Proteine. Diese wandern signalabhängig direkt zum Kern der Zelle, binden dort spezifisch an die DNA und haben somit direkten Einfluss auf die Transkription. Inzwischen wurden bereits eine ganze Familie von STAT-Proteinen sowie vier Mitglieder der JAK-Familie von rezeptorassoziierten Kinasen beschrieben. JAK1, JAK2, JAK3 und Tyk2 verfügen über eine carboxyterminale Kinase-Domäne und eine benachbarte funktionell inaktive homologe Domäne (Darnell et al. 1994; Levy und Darnell 2002).

Eine wichtige Gruppe dieser extrazellulären Botenstoffe in mehrzelligen Organismen sind die Zytokine. Es sind kleine Proteine bzw. Glykoproteine mit einem geringen Molekulargewicht (ca. $30 \mathrm{kDa}$ ). Alle Zytokinrezeptoren bestehen aus einer extrazellulären aminoterminalen Domäne, an der die Liganden-Bindung stattfindet, einer Transmembran-Domäne, die die Zellmembran nur einmal durchquert und einer intrazellulären, carboxyterminalen Domäne. Das bedeutet, dass alle Zytokin-Rezeptoren einen ähnlichen Strukturaufbau haben. Bei den Klasse I-Zytokin-Rezeptoren befindet sich in der extrazellulären Domäne eine konservierte Aminosäuresequenz, die die Klasse II-Zytokin-Rezeptoren nicht besitzen (Bazan 1989). Zytokine spielen eine wichtige Rolle in der Steuerung der Kontrolle des Aktivitätszustandes und der Immunantwort von immunkompetenten Zellen, aber auch bei Entwicklungs-, Differenzierungs- und 
Wachstumsprozessen. Als extrazelluläre Botenstoffe übertragen sie ihre Informationen in das Innere der Zelle. Dies geschieht über membranständige Rezeptoren. Ziel ist es dabei, eine Signalkaskade auszulösen, die eine Änderung des Genexpressionsprofils in der Zelle zur Folge hat (Schooltink und Rose-John 2002). Nach heutigem Forschungsstand gibt es mehr als fünfzig Zytokine, die über eine Bindung an ihren transmembranen Rezeptor den JAK-STAT-Signalweg initiieren (Shuai 1999; Gao 2005). Diese Zytokine sind phylogenetisch nicht verwandt; sie werden aufgrund funktioneller und struktureller Ähnlichkeiten in unterschiedliche Gruppen eingeteilt (Nicola 1994; Thomson 1998), zum Beispiel in Interleukine, Wachstumshormone oder Interferone (Schooltink und Rose-John 2002).

Für eine STAT-Aktivierung sind besonders die Interferone von Interesse. Diese tragen ihren Namen aufgrund ihrer Fähigkeit zur Interferenz mit Virusinfektionen (Isaacs und Lindenmann 1987). Sie werden nach PLATANIAS (2005) in drei strukturell nicht verwandte Gruppen unterteilt: Typ I- (IFNa, IFNß, IFNt, IFN $\omega$ ), Typ II- (IFNy) und das Typ III-Interferon $\lambda$. Den Typ I-Interferonen konnten antivirale Eigenschaften durch die Aktivierung von natürlichen Killer-Zellen nachgewiesen werden. Sie sind beim Menschen alle auf dem neunten Chromosom kodiert und werden in Leukozyten und Fibroblasten gebildet. Sie binden an einen gemeinsamen Klasse II-Zytokin-Rezeptor, der bei sämtlichen kernhaltigen Zellen auf der Oberfläche exprimiert wird (Novick et al. 1994). Die Typ II-Interferone (IFNY) sind hingegen auf dem zwölften Chromosom kodiert und werden nur in zytotoxischen Lymphozyten und T-Zellen hergestellt. Sie binden an ihren eigenen Klasse II-Zytokin-Rezeptor, der jedoch auf der Oberfläche aller kernhaltigen Zelltypen, ausgenommen der Erythrozyten, exprimiert wird (Langer und Pestka 1988). Die Typ II-Interferone sind als immunmodulatorische Zytokine mit weitreichender antimikrobieller Aktivität bekannt. Die Signalwege von Typ IIIInterferonen (IFN $\lambda$ ) sind bislang noch unzureichend erforscht, scheinen jedoch keine Bindung mit den typischen IFN-Rezeptoren einzugehen. Zusätzlich ist die Aktivität aller Interferone antiproliferativ (Chang et al. 1992).

Eine der Hauptaufgaben der Interferone ist es, durch Induktion der Transkription antiviral aktiver Komponenten des Immunsystems eine Virusinfektion abzuwehren. Hierbei spielt die Erkennung viraler RNA eine wichtige initierende Rolle. Bekannt ist die transkriptionelle Aktivierung der GTPase Mx, welche die Transkription der viralen RNA inhibiert (Frese et al. 1996). Eine weitere ist die Zerstörung der einzelsträngigen RNA in der Zelle durch aktivierte RNase L. Dazu binden kurze 2'-5'-Oligo-adenylat- 
Fragmente an die RNase. Diese werden durch Induktion der Expression von 2'-5'Oligoadenylat-Synthetasen produziert (Cironimo et al. 1997; Diaz-Guerra et al. 1997). Die zytokinabhängige Expression der RNA-abhängigen Proteinkinase $R$ (PKR) stellt einen dritten antiviralen Abwehrmechanismus dar. Nach Phosphorylierung inhibiert PKR zytokinabhängig die $\alpha$-Untereinheit des Translations-Initiationsfaktors elF2, wodurch es zu einer effizienten Hemmung der Translation viraler Proteine kommt (Meurs et al. 1992). Im Hinblick auf die Immunabwehr sind alle Interferone zudem in der Lage, die Expression von Genen des Major-Histokompatibilitätskomplexes I (MHC-I)-Molekülen zu induzieren. Jedoch ist es nur dem IFNy möglich, auch Proteine der MHC-Klasse II zu bilden (Revel und Chebath 1986; Boehm et al. 1997).

Durch die eingehende Untersuchung der Interferone wurde der JAK-STAT-Signalweg entdeckt. Dieser beinhaltet die Phosphorylierung von Signaltransduktoren und Aktivatoren der Transkription (STAT-Proteine) durch rezeptorassoziierte Kinasen (Darnell et al. 1994; Schindler und Darnell 1995). 


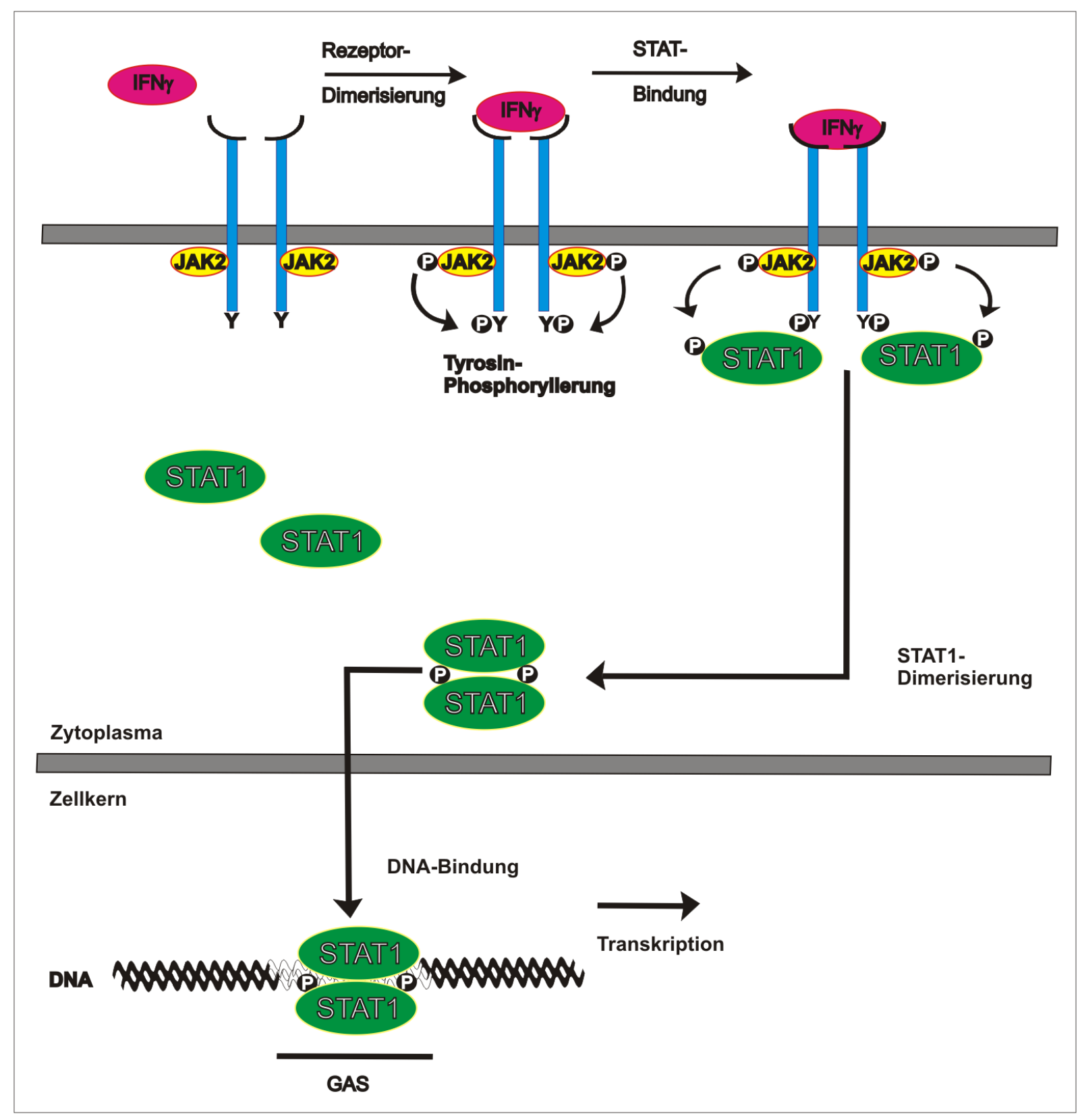

Abb. 1: Schematische Darstellung des durch IFNy vermittelten JAK-STAT-Signalwegs. Um eine Trans- und Autophosphorylierung der rezeptorassoziierten Janus-Kinasen auslösen zu können, wird eine Rezeptoroligomerisierung durch eine IFNY-Bindung initiiert. Kommt es zur Phosphorylierung von Tyrosinresten des Rezeptors im carboxyterminalen Molekülbereich durch JAK-Kinasen, werden Andockstellen für STAT1-Moleküle geschaffen. STAT1-Proteine werden ebenfalls durch JAK-Kinasen phosphoryliert, es kommt zur Ausbildung von Tyrosinphosphorylierten Homodimeren nach Rezeptorlösung und Einwanderung in den Zellkern. Durch Bindung an spezifische Zielsequenzen, die Gamma-aktivierten Sequenzen (GAS), erfolgt die Transkription von IFNY-regulierten Zielgene. 


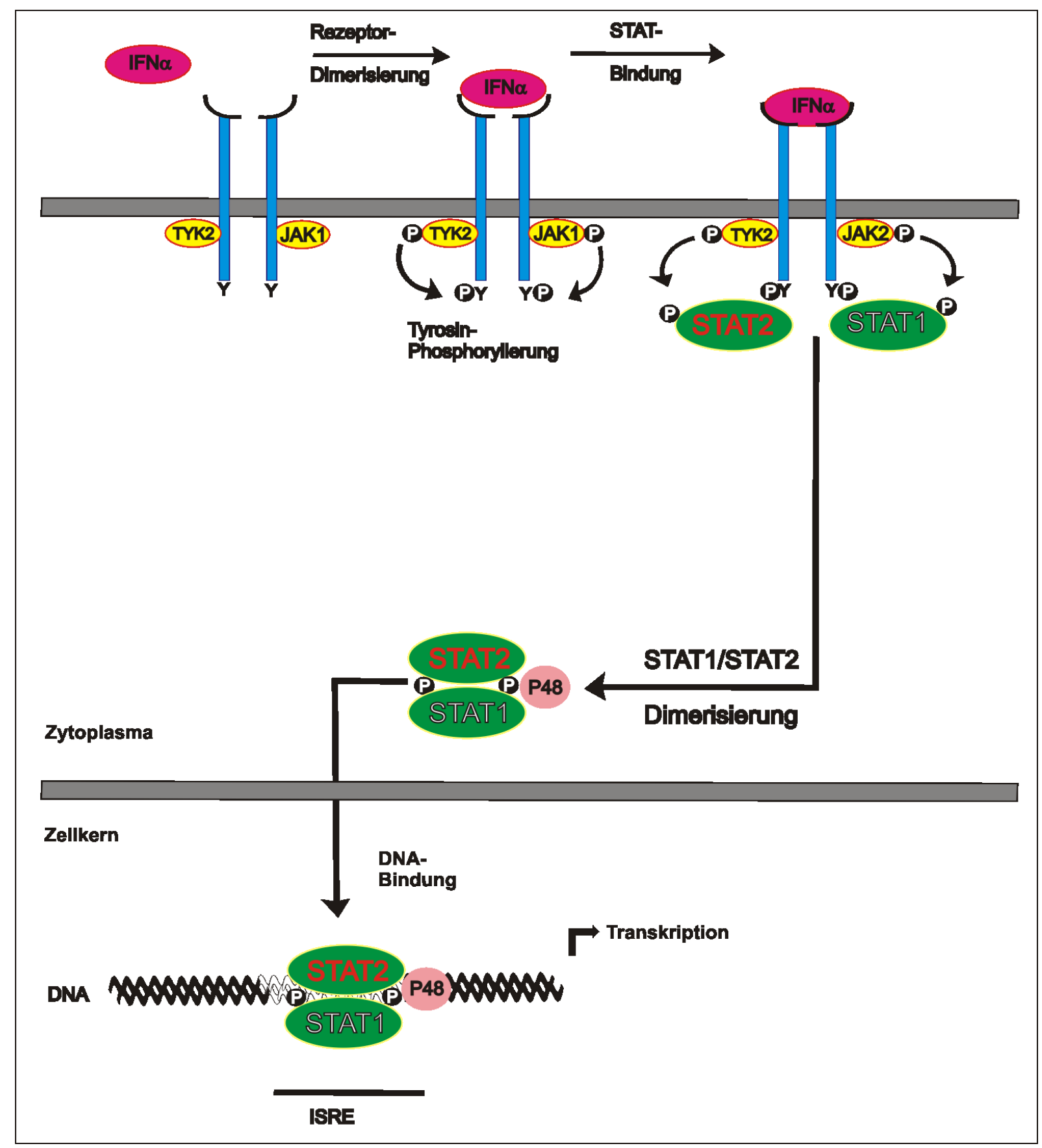




\begin{abstract}
Abb. 2: Schematische Darstellung der durch IFNa vermittelten STAT-Aktivierung. Die rezeptorvermittelte Kaskade startet durch die Bindung von IFNa an den Rezeptor und dessen Dimerisierung. Darauf folgt eine Aktivierung rezeptorassoziierter Janus-Kinasen (TYK2, JAK1), welche die Phosphorylierung der intrazellulären Rezeptorkette einleiten. Es bilden sich Andockstellen für STAT1- und STAT2-Proteine aus. Die STAT-Monomere bilden nach Phosphorylierung des kritischen Tyrosinrestes und Lösen vom Rezeptor STAT1/STAT2-Heterodimere aus. Nach Komplexbildung mit p48 gelangen diese in den Zellkern und induzieren dort die Genaktivierung durch Bindung an IFNa-spezifische Zielsequenzen (ISRE).
\end{abstract}


Nach Bindung des Zytokins an beide Rezeptoruntereinheiten erfolgt deren Homodimerisierung im Falle von IFNy (Abb. 1) oder Heterodimerisierung bei IFNa-Stimulation (Abb. 2). Dadurch kommt es zur Aktivierung der rezeptorassoziierten JanusKinasen (JAKs), die daraufhin die Tyrosinreste des Rezeptors phosphorylieren. Unphosphorylierte STAT-Proteine sowie andere Signalmoleküle binden an einen Phosphotyrosinrest des Rezeptors mit ihrer SH2 (Src-Homologie-2)-Domäne, woraufhin die STATs durch die Janus-Kinasen an einem in der STAT-Familie invarianten Tyrosinrest in der carboxyterminalen SH2-Domäne phosphoryliert werden (Shuai et al. 1993b). Dieser Vorgang führt zu einer Dimerisierung von phosphorylierten STATMonomeren (Shuai et al. 1994), die dann kurze Zeit später im Kern akkumulieren (Melén et al. 2001; Fagerlund et al. 2002). Der Import der STAT-Dimere erfolgt erst nach Bindung an Importine durch den intrazellulären Ran-Gradienten (Görlich et al. 1995; Moroianu et al. 1995; Fagerlund et al. 2002; McBride et al. 2002).

STAT-Dimere haben eine Größe von $\sim 180 \mathrm{kDa}$. Da es Makromolekülen, die größer als $40-60 \mathrm{kDa}$ sind, nicht möglich ist, mithilfe von freier Diffusion über den nukleären Porenkomplex (NPC) in den Zellkern zu gelangen, brauchen diese einen aktiven Transportmechanismus (Paine und Feldherr 1972; Weis 1998). Dadurch dass die hydrophoben phenylalanin-/glycinreichen Wiederholungssequenzen der Nukleoporine zur Interaktion mit Transportproteinen, wie zum Beispiel den Importinen, fähig sind, können auch die großen STAT-Dimere in den Zellkern gelangen (Radu et al. 1995a, b; Nigg 1997; Fahrenkrog et al. 2004). Ist ein STAT-Dimer schließlich in den Zellkern gelangt, wird die transkriptionelle Aktivierung von Zielgenen durch Bindung an spezifische Promotorregionen eingeleitet (Decker et al. 1997; Stark et al. 1998). Ist die DNA-Bindung beendet, kann die Dephosphorylierung bzw. die Inaktivierung der STAT-Dimere und daraufhin der Export, unterstützt aber nicht notwendig mithilfe von Exportinen, aus dem Zellkern zurück ins Zytoplasma erfolgen. Die Dephosphorylierung geschieht durch die nukleäre Phosphatase TC45 (ten Hoeve et al. 2002). 


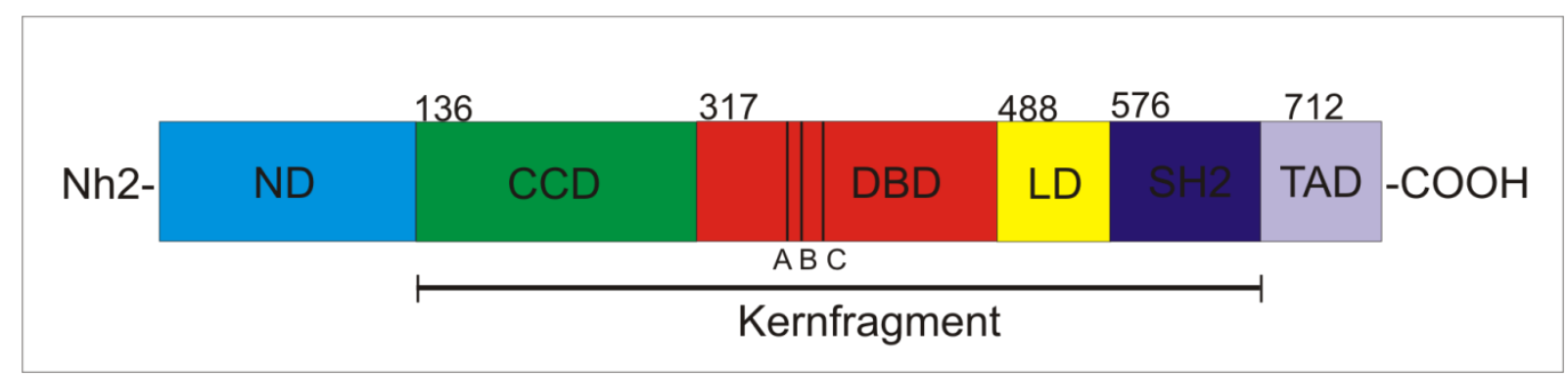

Abb. 3: Domänenstruktur von STAT1. Darstellung der Anordnung der unterschiedlichen Domänen am Beispiel von STAT1a: Aminoterminale Domäne (ND), Coiled-coil-Domäne (CCD), DNABindedomäne (DBD), Linker-Domäne (LD), Src-Homologie-2-Domäne (SH2) und Transaktivierungsdomäne (TAD). Vom Beginn der Coiled-coil-Domäne bis zur SH2-Domäne erstreckt sich das Kernfragment der STAT-Proteine. Innerhalb der DNA-Bindedomäne sind die für diese Arbeit verwendeten Aminosäuren durch drei Längsbalken markiert. A bezeichnet die Position 359, B 361 und C 367.

Seit der Entwicklung vielzelliger Eukaryonten ist die Familie der STAT-Proteine in sämtlichen tierischen Organismen konserviert. Dies gilt folglich nicht für Pilze und Pflanzen (Darnell 1997). Bisher konnte man die STATs in Schleimpilzen, trotz ihres Namens nicht zu den Pilzen gehörig, in Nematoden wie den Fadenwurm Caenorhabditis elegans, in Insekten (Yan et al. 1996; Kawata et al. 1997; Barillas-Mury et al. 1999; Liu et al. 1999) sowie in Vertebraten (Oates et al. 1999; Pascal et al. 2001; Sung et al. 2003) nachweisen. Bisher wurden sieben Mitglieder der humanen STATFamilie identifiziert (STAT1, STAT2, STAT3, STAT4, STAT5a, STAT5b und STAT6). Diese haben eine Länge von ca. 750-850 Aminosäureresten. Innerhalb der ersten 700 AS weisen sie eine Sequenzhomologie von 28-40\% auf (Schindler und Darnell 1995; Levy und Darnell 2002). Ihre genetische Information ist im menschlichen Genom auf drei verschiedenen Chromosomen lokalisiert. Die Gene für STAT1 und STAT4 liegen hier auf Chromosom 2, für STAT3, -5a und -5b auf Chromosom 17 und für STAT2 und STAT6 auf Chromosom 12 (Copeland et al. 1995). Die STAT-Proteine bestehen aus verschiedenen funktionellen Domänen (Hoey und Schindler 1998). Sie weisen einen gleichen charakteristischen Aufbau aus sechs funktionellen Domänenstrukturen auf und besitzen im carboxyterminalen Molekülbereich einen Tyrosinrest, der in phosphorylierter Form für die STAT-Dimerisierung benötigt wird (Schindler et al. 1992; Shuai et al. 1992; Shuai et al. 1993b). 
Viele Erkenntnisse über die Zusammenhänge von zytokinspezifischer Rezeptoraktivierung und den Funktionen der STAT-Proteine wurden durch Mausexperimente gewonnen (Akira 1999). STAT1-Knockout-Mäuse sind in ihrer Entwicklung nicht beeinträchtigt, weisen jedoch erhöhte Anfälligkeiten gegenüber bakteriellen und viralen Infektionen auf. Auch sind sie für Tumorbildung und -proliferation anfälliger (Shankaran et al. 2001). Obwohl in anderen Zytokinsignalwegen keine Regulationsstörungen vorliegen, ist die durch Typ-I- und Typ-II-IFN vermittelte Signaltransduktion bei STAT1-defizienten-Mäusen beeinträchtigt. Das heißt, dass ihre Immunität gegenüber viralen und bakteriellen Erregern deutlich beeinträchtigt ist, da STAT1 sowie STAT2 für die interferonvermittelte Immunantwort essentiell sind (Durbin et al. 1996; Horvath und Darnell 1996; Meraz et al. 1996). Bei STAT2-Knockout-Mäusen ist zwar die Signaltransduktion gehemmt, die durch Typ-I-Interferon stimuliert wird (Schindler et al. 1992a; Schindler und Darnell 1995), es besteht jedoch nur eine Immunschwäche gegen virale, nicht aber gegen bakterielle Infektionen (Park et al. 2000; Levy und Darnell 2002). STAT3-defiziente-Mäuse versterben bereits in der Embryonalphase, da STAT3 eine wichtige Rolle bei der uterinen Implantation spielt. Das Gen muss demnach im erwachsenen Alter ausgeschaltet werden, um Untersuchungen dieses Defizits möglich zu machen (O'Shea 1997; Takeda et al. 1997a). Ist das STAT3Protein in adulten Zellen ausgeschaltet, kommt es zur Unterdrückung der Zellteilung sowie der Zellproliferation und somit zu einer Störung der IL-6-getriggerten T-ZellProliferation sowie zu einer Beeinträchtigung der inflammatorisch bedingten Induktion von Akut-Phase-Proteinen in der Leber (Takeda und Akira 2000; Alonzi et al. 2001). STAT4-defiziente Mäuse haben einen Defekt bei der Differenzierung der T-HelferZellen zu TH1-Zellen, obwohl sie ansonsten lebensfähig und normal fruchtbar sind (Kaplan et al. 1996b; Takeda und Akira 2000; Wurster et al. 2000). Die murine Sequenz der Aminosäuren von STAT5a ist zu 96\% identisch mit der Sequenz von STAT5b (Mui et al. 1995). Dennoch verfügen STAT5a- bzw. STAT5b-Knockout-Mäuse über einen unterschiedlichen Phänotyp. Das bedeutet, dass ein STAT5a-Defizit nicht durch die Expression eines intakten STAT5b-Proteins ausgeglichen werden kann. Allerdings zeigen STAT5a-Knockout-Mäuse auffallend wenig Defekte. Bei STAT5adefizienten Mäusen wurden Defekte der Mammogenese mit Störung der Laktation beschrieben (Liu et al. 1997). Durch Forschung an STAT5b-defizienten Mäusen konnte gezeigt werden, dass STAT5b-Proteine für die Expression von geschlechtsspezifischen Leberproteinen und die geschlechtsspezifische Körpergröße von Be- 
deutung sind (Udy et al. 1997). STAT6 wird nur durch IL-4 und IL-13 aktiviert und reguliert somit die Entwicklung der T-Helfer-Zellen durch Induktion von TH2-Zellen. Fehlt nun das STAT6-Protein in Mäusen, führt dies zu einer defekten Entwicklung reifer TH2-Zellen. Zudem wurde eine Beeinträchtigung der Lymphozytenfunktion bei den Mäusen festgestellt (Kaplan et al. 1996a; O'Shea 1997; Takeda et al. 1997b). Neben einer gestörten IFNY-Synthese und einer beeinträchtigten Zytotoxizität natürlicher Killerzellen weisen sie zusätzlich eine Differenzierungsstörung naiver T-Helferzellen auf, die eine abnormale TH1-Entwicklung zur Folge hat (Kaplan et al. 1996b; Thierfelder et al. 1996).

Jedes STAT-Protein weist den gleichen Strukturaufbau auf; es handelt sich hierbei um funktionell und strukturell konservierte Domänen (Abb. 3). Schon seit längerem lässt sich der Beitrag einzelner Domänen durch Mutagenesestudien und Sequenzvergleiche innerhalb der STAT-Familie abschätzen. Dieses wird erleichtert durch die Möglichkeit der dreidimensionalen Darstellung der Kristallstruktur von STAT-Molekülen, wie beispielweise von STAT1 (Chen et al. 1998; Chen et al. 2003; Mao et al. 2005). 


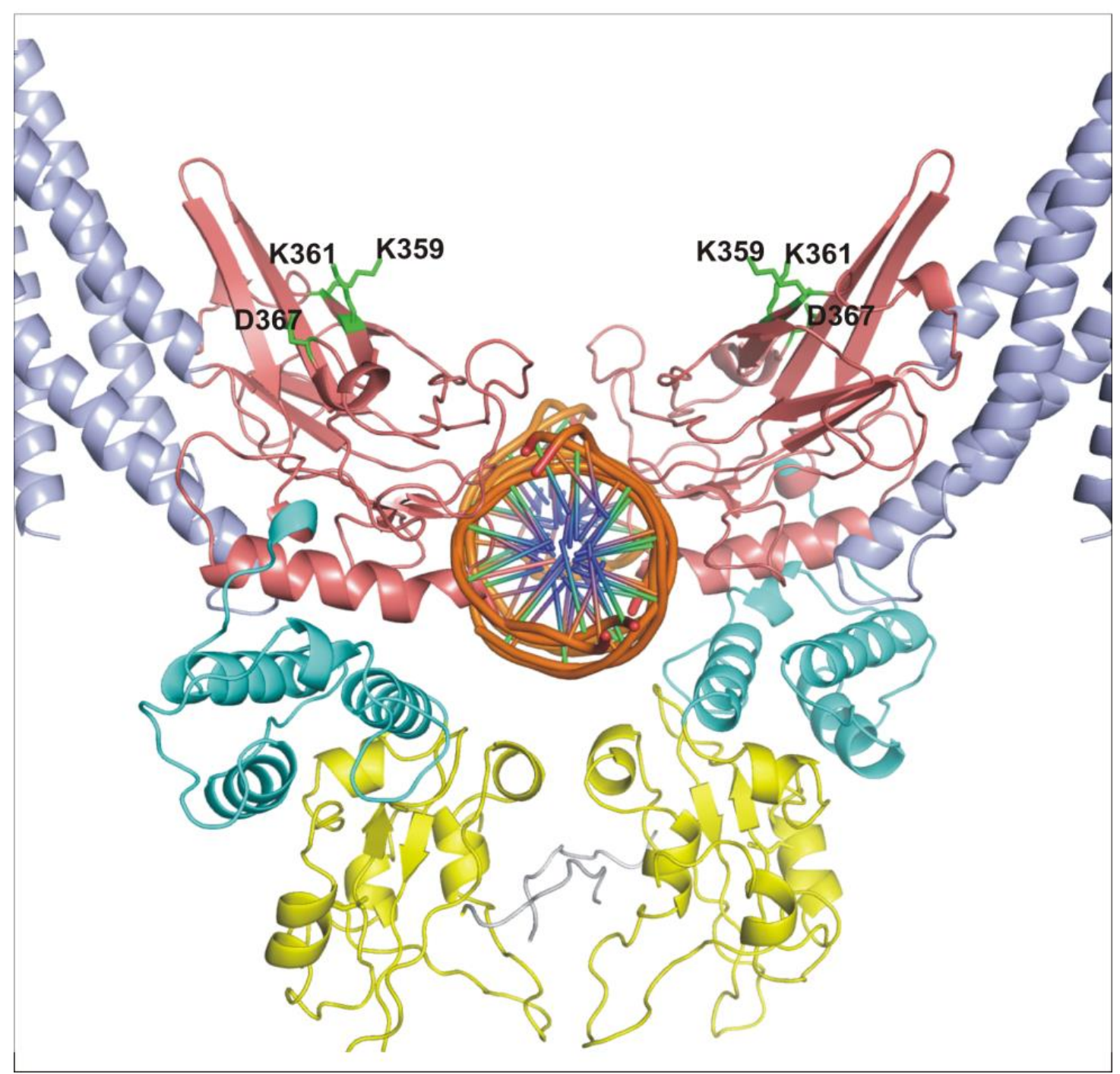

Abb. 4: Kristallstruktur eines DNA-gebundenen STAT1-Dimers. Pro Monomer sind jeweils die vier Domänen des Kernfragments von STAT1a dargestellt. Die Coiled-coil-Domäne ist in blass violett, die DNA-Bindedomäne in rosa, die Linker-Domäne in cyan und die SH2-Domäne in gelb hervorgehoben; die DNA im Zentrum ist in axialer Orientierung dargestellt. Die Lysinreste an den Positionen 359 und 361 sowie der Asparaginsäurerest an Position 367 (grün), die in dieser Arbeit näher untersucht werden, sind in der DNA-Bindedomäne mit ihren funktionellen Seitenketten lokalisiert. Diese Grafik ist mithilfe des Software-Programmes PyMol unter der Verwendung des Protein-Data-Bank-(PDB)-Koordinatendatensatzes 1BF5 hergestellt worden.

Wichtige Erkenntnisse zur Struktur wurden durch kristallographische Analysen von phosphorylierten DNA-gebundenen STAT1- und 3-Homodimeren gewonnen. Zwar umfassen diese Modelle nur das Kernfragment der STAT-Proteine, zeigen aber dennoch, dass sie in Form von Dimeren, die über eine SH2-Domäne untereinander in Verbindung stehen, mit der DNA interagieren (Becker et al. 1998; Chen et al. 1998). Durch die Aufklärung der Kristallstruktur der isolierten aminoterminalen Domäne von 
STAT4, die eine hohe Sequenzähnlichkeit zu STAT1 aufweist, gelang es, das Protein auch außerhalb des Kernfragmentes zu erforschen und ein Modell zu entwickeln, das Aufschluss über die Interaktion der Aminotermini von STAT1-Dimeren geben konnte (Baden et al. 1998; Chen et al. 1998; Vinkemeier et al. 1998; Chen et al. 2003). Überdies gelang es später, den STAT1-Aminoterminus im unphos-phorylierten, nicht DNA-gebundenen Molekül kristallographisch darzustellen (Mao et al. 2005). Mit diesen Modellen konnte auch gezeigt werden, dass STAT1-Dimere nicht in einheitlicher Konformation vorliegen, sondern in einer parallelen oder einer antiparallelen Form vorhanden sind, wofür der Unterschied in der Ausrichtung der SH2-Domäne liegt. Die SH2-Domänen zeigen demnach in dieselbe bzw. in die entgegengesetzte Richtung. Die Aminosäuresequenz dieses Bereiches, aber vor allem seine Länge, spielt hierbei eine wichtige Rolle (Mao et al. 2005; Mertens et al. 2006). Der Wechsel zwischen den beiden möglichen Konformationen wird durch eine flexible Region zwischen dem Aminoterminus sowie der Coiled-coil-Domäne realisiert (Mertens et al. 2006). Gegenseitige Wechselwirkungen der SH2-Domänen stabilisieren die parallele Form, während die antiparallele Form über reziproke aminoterminale Wechselwirkungen und Interaktionen der Coiled-coil-Domäne mit der DNA-Binde-domäne gefestigt wird. Für eine Bindung an den Rezeptor oder an die DNA ist die parallele Form essentiell. Um eine Dephosphorylierung durch die TC45-Phosphatase zu gewährleisten, ist wiederum die antiparallele Ausrichtung obligat (Mao et al. 2005; Zhong et al. 2005; Mertens et al. 2006; Wenta et al. 2008).

Die aminoterminale Domäne ist nach der SH2-Domäne die am höchsten konservierte Domäne innerhalb der STAT-Familie und umfasst die Aminosäuren 1 bis 135. Ihre Hauptfunktion scheint in der Vermittlung von Protein-Protein-Interaktion zu liegen. Diese ist essentiell für die Dimerisierung und die damit zusammenhängende kooperative DNA-Bindung. Die Protein-Protein-Interaktion erstreckt sich auf die bereits in der Kristallstruktur der isolierten STAT4-ND gezeigte Fähigkeit zur Homodimerisierung (Vinkemeier et al. 1998), die die Stabilität der DNA-Bindung bei der Bindung an benachbarte GAS-Stellen durch ND:ND-Interaktion zwischen den DNA-gebundenen Dimeren erhöht (Vinkemeier et al. 1996; Xu et al. 1996; Vinkemeier et al. 1998). An schwachen Promotoren wirkt die Oligomerisierung auf die DNA-Bindungsaktivität stabilisierend (John et al. 1999). Innerhalb der sieben STAT-Proteine weisen die jeweiligen aminoterminalen Domänen eine sehr ähnliche Struktur auf. Dennoch ist das Austauschen des Aminoterminus innerhalb der STAT-Familien nicht ohne weiteres 
möglich. Diese Erkenntnis lässt auf funktionelle Unterschiede der Aminotermini der einzelnen STAT-Mitgliedern schließen (Strehlow und Schindler 1998; Murphy et al. 2000). Um die wichtigen Funktionen der STAT-Proteine herauszuarbeiten, wurden verschiedene Mutationsexperimente durchgeführt. Der Aminoterminus ist in viele dieser Funktionen involviert (Shuai et al. 1996; Strehlow und Schindler 1998; Murphy et al. 2000). Als Beispiel befindet sich in der aminoterminalen Domäne von STAT1 ein Kernlokalisationssignal (NLS, Nuclear Localisation Signal), das durch die Interaktion mit Importinen den Kernimport des phosphorylierten STAT-Dimers ermöglicht (Meissner et al. 2004). Zudem konnten in der aminoterminalen Domäne von STAT1 Interaktionsoberflächen mit PIAS1-Proteinen, welche die DNA-Bindung von phosphoryliertem STAT1 blockieren (Liao et al. 2000; Leung et al. 1996; Darnell 1997; Horvath 2000; Shuai 2000), dem CREB-bindenden Protein CBP/p300 (Horvath 2000) und Zytokinrezeptoren (Leung et al. 1996; Murphy et al. 2000) identifiziert werden. Durch weitere Mutationsexperimente konnte beispielsweise in der Position 77 des STAT1Proteins ein konservierter Phenylalaninrest in der aminoterminalen Domäne identifiziert werden. Nach Mutation dieses Restes zu Alanin wird die Fähigkeit zur Tetramerisierung von STAT1-Molekülen unterbunden. Somit ist sowohl das Vermögen der kooperativen DNA-Bindung gehemmt als auch die transkriptionelle Aktivität vermindert (Meyer et al. 2004). Schlussendlich befindet sich im carboxyterminalen Abschnitt der aminoterminalen Domäne ein flexibler Bereich, der zur Coiled-coil-Domäne überleitet.

Die Coiled-coil-Domäne besteht aus 4 antiparallelen $\alpha$-Helices, weshalb sie auch als 4-Helix-Bündel bezeichnet wird. Sie ist 149-187 AS lang und für die Bindung an Zytokinrezeptoren verantwortlich (Zhang et al. 2000). Die Coiled-coil-Domäne interagiert mit Proteinen im Sinne einer Protein-Protein-Interaktionsdomäne (Zhang et al. 2002). In ihr befindet sich eine zweite Interaktionsfläche, die in der Lage ist, eine Bindung zur DNA-Bindedomäne (DBD) eines weiteren Monomers herzustellen. Dies geschieht von Monomer zu Monomer mit Beteiligung der Reste Q340, T385, H406 und Q408 und trägt zur Stabilisierung der antiparallelen Konformation bei (Mao et al. 2005; Mertens et al. 2006). Weiterhin enthält die Coiled-coil-Domäne bei STAT3 sowie bei STAT5 ein kernlokalisiertes Signal (NLS) (Liu et al. 2005; Zeng et al. 2002) und bei STAT1 ein nukleäres Exportsignal in der leucinreichen, helikalen Region (Begitt et al. 2000). 
Die DNA-bindende Domäne von STAT1 besteht aus 172 AS, mehreren $\beta$-Faltblättern und Schleifen. Sie hat eine immunglobulinähnliche Tertiärstruktur, die der vom nukleären Faktor (NF-kB) und p53 sehr ähnlich ist (Chen et al. 1998). Die Hauptfunktion der DNA-Bindedomäne besteht in der sehr ausgeprägten Interaktion mit DNASequenzen (Wegenka et al. 1993; Sadowski et al. 1993) mit nanomolaren Gleichgewichts-Dissoziationskonstanten (Vinkemeier et al. 1996), bei denen jedes phosphorylierte Monomer eine Bindung mit einer halben palindromischen GAS-Bindestelle eingeht (Chen et al. 1998). Nachdem die Kristallstruktur untersucht wurde, konnte dargestellt werden, dass es zu einer Bindung mit der DNA über die große und kleine Furche der Doppelhelix kommt. Die Aminosäurereste N460 und K336 interagieren mit der großen und E421 mit der kleinen Furche (Chen et al. 1998). Die DNABindedomäne verfügt über eine spezifische Bindung an die DNA, die jedoch durch Mutationen aufgehoben werden kann. Das die DNA-Bindung so präzise ist, ist einem konservierten Bereich innerhalb der DNA-Bindedomäne zwischen den Aminosäureresten 400-500 zu verdanken (Darnell 1997; Horvath et al. 1995). Über das Kernlokalisationssignal (NLS) der DNA-Bindedomäne ist es möglich eine Bindung an Importin-a5 zu vermitteln und somit den Kernimport zu sichern (Fagerlund et al. 2002; McBride et al. 2002; Meyer et al. 2002). Die DNA-Bindedomäne enthält zudem zwei durch rationale Mutagenese erzeugte Aminosäurereste, die bemerkenswerte Effekte auf die Dephosphorylierung der Mutanten, die DNA-Bindung und die damit verbundene Haftung im Zellkern aufweisen.

Die Linker-Domäne (LD) ist 88-95 AS lang und liegt als Bindeglied zwischen der DNA-Bindedomäne und der SH2-Domäne, mit der sie über eine phosphatbindende Schleife kommuniziert. Sie besteht, ähnlich wie die Coiled-coil-Domäne, aus mehreren a-Helices (Chen et al. 1998). Durch spezifische Mutationen konnten Veränderungen, zum Beispiel in Bezug auf die transkriptionelle Aktivität an STAT1, beschrieben werden (Yang et al. 1999), wobei diese Aktivität durch strukturelle Veränderungen in der nachgeschalteten SH2-Domäne die DNA-Bindung induziert (Chen et al. 1998). Auch vermittelt sie bei STAT3 eine Interaktion mit dem proapoptotischen Faktor GRIM19 (Lufei et al. 2003). Ebenso wurde die DNA-Bindung der Linker-Domäne erforscht. Darüber hinaus ist die Linker-Domäne noch weitestgehend unbekannt.

Die am stärksten konservierte STAT-Domäne aus 100 Aminosäureresten ist die SH2Domäne (Chen et al. 1998; Schindler und Darnell 1995). Ihre Grundstruktur ( $\alpha \beta \beta \beta \alpha)$ besteht aus einem antiparallelen $\beta$-Faltblattmotiv $(\beta B-\beta D)$, das wiederum von zwei $\alpha$ - 
Helices ( $\mathrm{\alpha A}$ und $\mathrm{\alpha B}$ ) eingeklammert ist (Chen et al. 1998; Gao et al. 2004; Waksman et al. 1992). Ihren Namen erhielt die SH2-Domäne durch die Sequenz der TyrosinKinase Src, in der sie aminoterminal der Kinase-Domäne (SH1-Domäne) identifiziert wurde (Koch et al. 1991; Pawson 1988; Sadowski et al.1986). Durch die SH2Domäne können die STATs miteinander interagieren (Shuai et al. 1994; Gupta et al. 1996) und eine Bindung mit den Phosphotyrosin-Resten der Zytokin-Rezeptoren eingehen (Greenlund et al. 1995; Schindler et al. 1995). Diese Rezeptoren sind für die Signalweiterleitung von Bedeutung (Mayer und Hanafusa 1990; Mayer et al. 1991), bei der zwei Hauptaufgaben hervorzuheben sind: Die Vermittlung der Bindung an phosphorylierte Abschnitte von membranständigen Rezeptoren bzw. an intrazellulären Tyrosin-Kinasen (Shuai et al. 1994; Becker et al. 1998) und die Homo- bzw. Heterodimerisierung von phosphorylierten STAT-Monomeren. Letzteres geschieht durch die wechselwirkende Interaktion der SH2-Domäne mit einem konstanten phosphorylierten Tyrosinrest eines anderen STAT-Moleküls, wie zum Beispiel dem Tyr701 bei STAT1. Hierbei wurde an Position 602 ein Argininrest dargestellt, der in allen bekannten SH2-Domänen konserviert und an der Dimerisierung von STAT1 beteiligt ist (Chen et al. 1998; Shuai et al. 1993b, 1994). Dieser Mechanismus der Phosphotyrosin:SH2-Interaktion ähnelt dem von anderen Proteinen sehr (Kuriyan und Cowburn 1997), obwohl große Unterschiede zwischen SH2-Domänen bestehen, von denen im menschlichen Genom an die 200 verschiedene vorhanden sind (Gao et al. 2004; Kawata et al. 1997; Darnell 1997).

Die Transaktivierungsdomäne (TAD) ist eine der am wenigsten konservierten Domänen der STAT-Familie mit einer nicht festgelegten Länge von ca. 40 Aminosäuren bei STAT1 und bis zu 200 Aminosäuren bei STAT6 (Levy und Darnell 2002). Es wird vermutet, dass dieser Umstand bei den STATs ausschlaggebend für die Spezifität der Zielgene ist. Die Transaktivierungsdomäne enthält den bereits oben erwähnten kritischen Tyrosinrest 701, der unter anderem für die transkriptionelle Aktivität von Bedeutung ist und von den Janus-Kinasen phosphoryliert wird (Schindler et al. 1992b; Shuai et al. 1992). Bei einigen Mitgliedern der STAT-Familie, wie zum Beispiel STAT1 und STAT3, konnte ein invarianter Serinrest in der Transaktivierungsdomäne auf Position 727 detektiert werden, der bei einer Phosphorylierung durch unterschiedliche Stimuli zu maximaler transkriptioneller Aktivierung führt (Wen et al. 1995; Zhang et al. 1995; Decker und Kovarik 2000). Zudem vermittelt die Transaktivierungsdomäne den durch Stress induzierten Zelltod (Janjua et al. 2002; Stephanou und Latchman 2003) 
und eine Protein:Protein-Interaktionen mit CBP/p300 (Zhang et al. 1996), MCM5 (Zhang et al. 1998), BRCA1 (Ouchi et al. 2000) und NCOA1 (Litterst und Pfitzner 2001).

Diese Arbeit befasst sich mit der Generierung von Punktmutationen innerhalb der DNA-Bindedomäne von STAT1 und deren Auswirkungen auf das Protein und dessen Verhaltensweisen bezüglich der Kernakkumulation, der Genaktivierung sowie der Phosphorylierung. Hierzu wurden verschiedene Experimente durchgeführt. Die ausgewählten Aminosäuren sind konserviert und somit für das STAT-Protein mutmaßlich von Bedeutung. Sie liegen in der DNA-Bindedomäne, weit von der DNA entfernt und könnten dennoch unmittelbar an der DNA-Bindung beteiligt sein. Durch den Einsatz standardisierter Untersuchungsverfahren soll versucht werden, mögliche abweichende Eigenschaften der mutierten STAT1-Proteine mit verschiedenen Methoden zu verifizieren, um mithilfe dieser Ergebnisse Aussagen über den Phänotyp der einzelnen Mutanten sowie deren Einfluss auf den JAK-STAT-Signalweg zu treffen. 


\section{Material und Methoden}

\subsection{Material}

\subsubsection{Humane Zelllinien}

HeLa Humane Epithelzellen eines Zervixkarzinoms mit etablierter permanenter Zelllinie (bezogen von Prof. Dr. U. Vinkemeier) $\begin{array}{ll}\text { U3A } & \begin{array}{l}\text { aus 2fTGH entstandene STAT1-defiziente Zellinie (bezogen von Prof. Dr. U. } \\ \text { Vinkemeier) }\end{array}\end{array}$

\subsubsection{Chemikalienliste}

\begin{tabular}{l|l} 
Agar & Carl Roth, Karlsruhe \\
\hline Ammoniumperoxodisulfat & Carl Roth \\
\hline Ampicillin & Sigma-Aldrich \\
\hline Borsäure & $\begin{array}{l}\text { AmershamPharmacia Biotech, } \\
\text { Freiburg }\end{array}$ \\
\hline Bromphenol-Blau & Sigma-Aldrich \\
\hline Dimethylsulfoxid (DMSO) & Carl Roth \\
\hline Dithiothreitol (DTT) & AppliChem, Darmstadt \\
\hline Ethanol & Carl Roth \\
\hline Ethylendiamin-N,N,N',N'-tetraessigsäure & Acros Organics \\
(EDTA) & Carl Roth \\
\hline Ethylenglycol-bis(ethylennitrilo)-N,N,N',N'- \\
tetraessigsäure (EGTA) & Amersham Bioscience, Freiburg \\
\hline Ficoll-Paque Plus & Carl Roth \\
\hline Formaldehyd & Carl Roth \\
\hline Glycin & Carl Roth \\
\hline Glycerin &
\end{tabular}




\begin{tabular}{|c|c|}
\hline Glycylglycin & Sigma-Aldrich \\
\hline $\begin{array}{l}\mathrm{N}-(2-\text {-Hydroxyethyl)-1- } \\
\text { piperazinoethansulfonsäure (HEPES) }\end{array}$ & Carl Roth \\
\hline Hefeextrakt & Carl Roth \\
\hline IGEPAL-CA-360 & Sigma-Aldrich \\
\hline Kaliumchlorid & Carl Roth \\
\hline Kanamycin & Sigma-Aldrich \\
\hline$\beta$-Mercaptoethanol & Sigma-Aldrich \\
\hline Magnesiumchlorid-6-hydrat & Sigma-Aldrich \\
\hline Magnesiumsulfat & Carl Roth \\
\hline Methanol & Sigma-Aldrich \\
\hline Natriumcarbonat & Carl Roth \\
\hline Natriumchlorid & Sigma-Aldrich \\
\hline Natriumdodecylsulfat (SDS) & Carl Roth \\
\hline Natrium-ortho-vanadat & Sigma-Aldrich \\
\hline Ortho-Nitrophenyl- $\beta$-D-Galactopyranosid & Sigma-Aldrich \\
\hline Pefabloc SC & Roche, Grenzach \\
\hline 2-Propanol & Carl Roth \\
\hline Rinderserumalbumin (BSA) & Carl Roth \\
\hline Rotiphorese Gel & Carl Roth \\
\hline Salzsäure & Carl Roth \\
\hline Staurosporin & Sigma-Aldrich \\
\hline $\mathrm{N}, \mathrm{N}, \mathrm{N}^{\prime}, \mathrm{N}^{\prime}-$ Tetramethylethylendiamin (TEMED) & Carl Roth \\
\hline
\end{tabular}




\begin{tabular}{l|l} 
Tris-Hydrochlorid (Tris-HCl) & Carl Roth \\
\hline Tris-(hydroxymethyl)-aminomethan (Tris-Base) & Carl Roth \\
\hline Triton X-100 & Sigma-Aldrich \\
\hline Trypton & Carl Roth \\
\hline Tween-20 & Sigma-Aldrich \\
\hline Wasserstoffperoxid & Carl Roth
\end{tabular}

\subsubsection{Radiochemikalien}

Die $\alpha-\left[{ }^{33} \mathrm{P}\right]$-markierten Desoxynukleotide wurden vor Ablauf ihrer Halbwertszeit eingesetzt und besaßen eine spezifische Aktivität von $111 \mathrm{Tbq} / \mathrm{mmol}$ (Hartmann Analytic, Braunschweig).

\subsubsection{Puffer, Lösungen und Medien}

Alle Puffer, Lösungen und Medien wurden mit entionisiertem Wasser der MilliporeAnlage Milli-Q (Millipore, Schwalbach) hergestellt. Über einen Molekülfilter mit einer Porengröße von 0,22 $\mu \mathrm{m}$ filtert die Anlage Wasser. Der pH-Wert einzelner Lösungen wurde mithilfe des pH-Meters Seven Easy (Mettler Toledo, Gießen) eingestellt. Bei Bedarf konnten einzelne Lösungen über 0,2 $\mu \mathrm{m}$-Filter steril filtriert werden.

\subsubsection{Antikörper}

\begin{tabular}{l|l}
$\begin{array}{l}\text { IRDye 800CW Anti-Kaninchen-IgG aus } \\
\text { Ziege }\end{array}$ & LI-COR Biosciences, Bad Homburg \\
\hline STAT3 (H-190) & $\begin{array}{l}\text { Santa Cruz Biotechnology, Santa } \\
\text { Cruz, CA, USA }\end{array}$ \\
\hline Phospho-STAT1 (Tyr 701) & Cell Signaling, Danvers, Ma, USA \\
\hline STAT1a-p91 (C-24) & Santa Cruz Biotechnology
\end{tabular}


Cy3-gekoppeltes Anti-Kaninchen-lgG aus Ziege
Jackson ImmunoResearch, Suffolk, UK

Bei der immunzytochemischen Untersuchung wurde der Antikörper C-24 im Verhältnis 1:1000 in 25\% FBS mit PBS als Erstantikörper und das Cy3-gekoppelte AntiKaninchen-IgG aus Ziege als Zweitantikörper im Verhältnis 1:500 in 25\% FBS in PBS eingesetzt. Während einer Supershift-Reaktion bei sogenannten EMSA-Experimenten wurden die polyklonalen Antikörper STAT1a-p91 (C-24) und STAT3 (H190) mit einer Verdünnung von 1:9 in PBS (Karlsruhe, Gibco) verwendet. Für das WesternBlot-Experiment wurden polyklonale Antikörper (STAT1a-p91 C-24) und PhosphoSTAT1 (Tyr 701)) als Primärantikörper verwendet. Die Verdünnung belief sich auf 1:1000 in 4\% BSA mit TBS-T (0,05\% Tween-20, pH 7,4, $137 \mathrm{mM} \mathrm{NaCl}, 10 \mathrm{mM}$ Tris$\mathrm{HCl}$ ). Das polyklonale IRDye $800 \mathrm{CW}$ Anti-Kaninchen-IgG aus Ziege, das in einer Verdünnung von 1:10.000 in 4\% BSA mit TBS-T seine Verwendung fand, wurde als Sekundärantikörper gehandhabt.

\subsubsection{Reaktionskits}

\begin{tabular}{l|l} 
Absolute-Blue-QPCR-SYBR-Green-Mix & Thermo Scientific, Dreieich \\
\hline Luciferase-Assay-System & Promega; Mannheim \\
\hline peqGold-Plasmid-Miniprep-Kit & Peqlab \\
\hline peqGold-total-RNA-Kit Safety-Line & Peqlab \\
\hline QIAGEN-Plasmid-Maxi-Kit & Qiagen, Hilden \\
\hline QuikChange® II Site-Directed Mutagenesis-Kit & Stratagene \\
\hline Verso-CDNA-Kit & Thermo Fisher Scientific
\end{tabular}




\subsubsection{Enzyme}

\begin{tabular}{l|l} 
Complete-Mini Protease Inhibitoren & Roche, Grenzach \\
\hline DNA-Polymerase I (Klenow-Enzym) & $\begin{array}{l}\text { New England Biolabs, Schwal- } \\
\text { bach }\end{array}$ \\
\hline Dpn I-Endonuklease und PfuUltra-HF & Stratagene, La Jolla, USA \\
\hline PfuTurbo DNA-Polymerase & Stratagene \\
\hline $\begin{array}{l}\text { T-Zell-Protein Tyrosin-Phosphatase (human, } \\
\text { rekombinant, C-terminale 11 kDa-Deletion } \\
\text { (TCAC11, Reste 1-317), exprimiert in E. colI) }\end{array}$ & $\begin{array}{l}\text { Biomol-International, Plymouth, } \\
\text { USA }\end{array}$ \\
\hline Trypsin/EDTA-Lösung & PAA, Pasching, Österreich
\end{tabular}

\subsubsection{Zytokine}

Es wurde humanes Interferon-y (IFNY) der Firma Biomol in Hamburg für die Stimulation der Zellen eingesetzt. IFNy wurde, wenn nicht anders verlangt, in dem jeweiligen Medium der Zellkultur 1:1000 verdünnt und auf die Zellen pipettiert. 
2.1.9 Plasmide

\begin{tabular}{|c|c|c|}
\hline pEGFP-N1 & $\begin{array}{l}\text { 4,7kb langer, optimierter Vektor mit } \\
\text { verbesserter Fluoreszenz zur Ex- } \\
\text { pression von N-terminalen GFP- } \\
\text { Fusionsplasmiden in Säugerzellen }\end{array}$ & Clonetech, Mountain View, USA \\
\hline pSTAT1a-GFP & $\begin{array}{l}\text { Humane STAT1a-cDNA } \\
\text { (AS 1- 747) in pEGFP-N1 }\end{array}$ & Begitt et al. 2000 \\
\hline $\begin{array}{l}\text { pSTAT1 } \alpha(K 359 A)- \\
\text { GFP }\end{array}$ & $\begin{array}{l}\text { durch sequenzspezifische Mutation } \\
\text { entstandenes Derivat von STAT1a- } \\
\text { GFP1, verwendetes Primerpaar: } \\
\text { K359AF/K359AR }\end{array}$ & die vorliegende Arbeit \\
\hline $\begin{array}{l}\text { pSTAT1a(K361A)- } \\
\text { GFP }\end{array}$ & $\begin{array}{l}\text { durch sequenzspezifische Mutation } \\
\text { entstandenes Derivat von STAT1a- } \\
\text { GFP1, verwendetes Primerpaar: } \\
\text { K361AF/D367AR }\end{array}$ & die vorliegende Arbeit \\
\hline $\begin{array}{l}\text { pSTAT1a(D367A)- } \\
\text { GFP }\end{array}$ & $\begin{array}{l}\text { durch sequenzspezifische Mutation } \\
\text { entstandenes Derivat von STAT1a- } \\
\text { GFP1, verwendetes Primerpaar: } \\
\text { D367AF/D367AR }\end{array}$ & die vorliegende Arbeit \\
\hline pcDNA3.1 & $\begin{array}{l}\text { 5,4kb langer, eukaryotischer Expres- } \\
\text { sionsvektor }\end{array}$ & Invitrogen \\
\hline pcDNA3.1-STAT1 $\alpha$ & $\begin{array}{l}\text { humane STAT1 } \alpha-c D N A \text { kloniert in } \\
\text { pcDNA3.1 }\end{array}$ & $\begin{array}{l}\text { Dr. James E. Darnell, } \\
\text { New York, USA }\end{array}$ \\
\hline $\begin{array}{l}\text { pcDNA3.1- } \\
\text { STAT1a(K359A) }\end{array}$ & $\begin{array}{l}\text { durch sequenzspezifische Mutation } \\
\text { entstandenes Derivat von pcD- } \\
\text { NA3.1-STAT1a, verwendetes Pri- } \\
\text { merpaar: K359AF/K359AR }\end{array}$ & die vorliegende Arbeit \\
\hline
\end{tabular}




\begin{tabular}{|c|c|c|}
\hline $\begin{array}{l}\text { pcDNA3.1- } \\
\text { STAT1a }(K 361 A)\end{array}$ & $\begin{array}{l}\text { durch sequenzspezifische Mutation } \\
\text { entstandenes Derivat von pcD- } \\
\text { NA3.1-STAT1a, verwendetes Pri- } \\
\text { merpaar: K361AF/D367AR }\end{array}$ & die vorliegende Arbeit \\
\hline $\begin{array}{l}\text { pcDNA3.1- } \\
\text { STAT1a(D367A) }\end{array}$ & $\begin{array}{l}\text { durch sequenzspezifische Mutation } \\
\text { entstandenes Derivat von pcD- } \\
\text { NA3.1-STAT1a, verwendetes Pri- } \\
\text { merpaar: D367AF/D367AR }\end{array}$ & die vorliegende Arbeit \\
\hline $\mathrm{p} \beta \mathrm{Gal}$ & $\begin{array}{l}\text { 7,4kb langer Expressionsvektor der } \\
\beta \text {-Galaktosidase }\end{array}$ & Stratagene, La Jolla, USA \\
\hline pGAS3xLy6E & $\begin{array}{l}\text { Reportergenkonstrukt mit drei GAS- } \\
\text { Bindestellen }\end{array}$ & Wen et al. 1995 \\
\hline
\end{tabular}

Das Akronym pSTAT1a-GFP wird im Verlauf durch die Bezeichnung pSTAT1-GFP ersetzt, da in dieser Arbeit nur mit STAT1a-kodierten Plasmiden gearbeitet wurde. Der Begriff pSTAT1 wird außerdem bei der Verwendung von pcDNA3.1-STAT1aPlasmiden benutzt.

\section{$\underline{\text { 2.1.10 Oligonukleotide }}$}

\section{Primer für die sequenzspezifische Mutagenese}

\begin{tabular}{l|l}
\hline K359A F & 5'-gctgaattataatttggcagtcaaagtcttatttgataaag-3‘ $^{`}$ \\
\hline K359A R & 5'-ctttatcaaataagactttgactgccaaatttataattcagc-3' \\
\hline D361A F & 5'-gaattataatttgaaagtcgcagtcttatttgataaagatg-3‘ \\
\hline K361A R & 5'-catctttatcaaataagactgcgactttcaaattataattc-3‘
\end{tabular}




\begin{tabular}{l|l} 
D367A F & 5'-caaagtcttatttgataaagctgtgaatgagagaaatac-3 \\
\hline D367A R & 5'-gtatttctctcattcacagctttatcaaataagactttg-3‘ \\
\hline
\end{tabular}

\section{Primer für die Sequenzierung}

\begin{tabular}{l|l}
\hline $484 f$ & $5^{\prime}$-ccttcttcctgactccacca-3' \\
\hline $611 r$ & $5^{\prime}$-ctccacccatgtgaatgtga-3' \\
\hline
\end{tabular}

Olgonukleotid-Sonden für den Elektrophoretischen-Mobilitäts-Shift-Assay

\begin{tabular}{l|l}
\hline M67 F & $5^{\prime}$-tttcgacatttcccgtaaatctg-3' \\
\hline M67 R & $5^{\prime}$-ttttcagatttacgggaaatgtcg-3' \\
\hline GAS-nonGAS F & $5^{\prime}$-tttcgtttccccgaaattgacggatttaccccaac-3' \\
\hline GAS-nonGAS R & $5^{\prime}$-ttttgttggggtaaatccgtcaatttcggggaaacg-3' \\
\hline 2xGAS F & $5^{\prime}$-tttttgtttccccgaaattgacggatttccccgaaac-3' \\
\hline 2xGAS R & $5^{\prime}$-tttttgttcggggaaatccgtcaatttcggggaaac-3' \\
\hline 2xnonGAS F & $5^{\prime}$-ttttcgtttaccccaaattgacggatttaccccaac-3' \\
\hline 2xnonGAS R & $5^{\prime}$-ttttgttggggtaaatccgtcaatttggggtaaacg-3' \\
\hline
\end{tabular}

\section{Primer für die RT-PCR}

\begin{tabular}{l|l}
\hline hGAPDH F & 5'-gaaggtgaaggtcggagtc-3' \\
\hline hGAPDH R & 5'-gaagatggtgatgggatttc-3‘
\end{tabular}




\begin{tabular}{l|l} 
hIRF1 F & 5'-agctcagctgtgcgagtgta-3' \\
\hline hIRF1 R & 5'-tagctgctgtggtcatcagg-3' \\
\hline hGBP1 F & 5'-ggtccagttgctgaaagagc-3' \\
\hline hGBP1 R & 5'-tgacaggaaggctctggtct-3' \\
\hline hMIG1 F & 5'-ccaccgagatccttatcgaa-3' \\
\hline hMIG1 R & 5'-ctaaccgacttggctgcttc-3' \\
\hline hSTAT1 F & 5'-ccgtttcatgacctcctgt-3' \\
\hline hSTAT1 R & 5'-tgaatattccccgactgagc-3' \\
\hline
\end{tabular}

Die angegebenen Oligonukleotide wurden von den Firmen Hartmann Analytic (Braunschweig), Sigma-Aldrich (Taufkirchen), Invitrogen (Darmstadt) und Tib MolBiol (Berlin) bezogen.

\subsubsection{Bakterienstämme und Medien}

\begin{tabular}{|c|c|}
\hline \multirow{2}{*}{ E.coli DH5a } & Stratagene, La Jolla, (USA) \\
\hline & 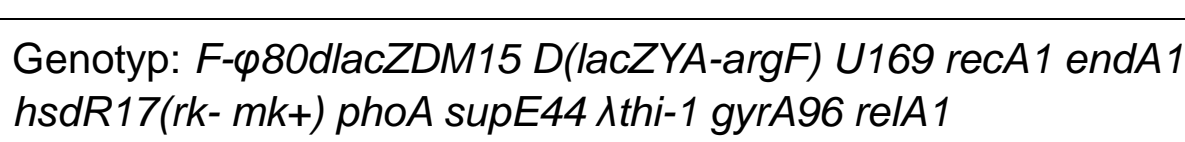 \\
\hline \multirow{2}{*}{$\begin{array}{l}\text { E.coli XL1- } \\
\text { Blue }\end{array}$} & Stratagene, La Jolla, (USA) \\
\hline & $\begin{array}{l}\text { Genotyp: recA1 endA1 gyrA96 thi-1 hsdR17 supE44 relA1 lac } \\
\text { [F'proAB laclqZ } \Delta M 15 \text { Tn10 (Tetr)] }\end{array}$ \\
\hline
\end{tabular}

Für die Anzucht der Bakterien wurden LB-Flüssigmedium, SOC-Medium oder LBAgarplatten verwendet, deren Komponenten sich wie folgt zusammensetzten: 


\begin{tabular}{l|l|l} 
LB-Medium & LB-Agar & SOC-Medium \\
\hline $1 \%$ Trypton & $1 \%$ Trypton & $2 \%$ Trypton \\
\hline $0,5 \%$ Hefeextrakt & $0,5 \%$ Hefeextrakt & $0,5 \%$ Hefeextrakt \\
\hline $1 \% \mathrm{NaCl}$ & $1 \% \mathrm{NaCl}$ & $10 \mathrm{mM} \mathrm{NaCl}$ \\
\hline \multirow{2}{*}{$\begin{array}{l}\mathrm{pH} 7,0(\text { eingestellt durch } \\
\mathrm{NaOH})\end{array}$} & $1,5 \%$ Agar-Agar & $2,5 \mathrm{mM} \mathrm{Kcl}$ \\
\cline { 2 - 3 } & $\begin{array}{l}\mathrm{pH} 7,0 \text { (eingestellt durch } \\
\mathrm{NaOH})\end{array}$ & $20 \mathrm{mM} \mathrm{MgSO} 4$ \\
\cline { 2 - 3 } & $\mathrm{pH} \mathrm{7,5}$
\end{tabular}

Die LB-Agarplatten sowie das LB-Flüssigmedium wurden bei 1,5 bar und $121^{\circ} \mathrm{C}$ für 30 min autoklaviert. Nach dem Autoklavieren wurden dem LB-Agar und LB-Medium Kanamycin $(50 \mu \mathrm{g} / \mathrm{ml})$ oder Ampicillin $(100 \mu \mathrm{g} / \mathrm{ml})$ hinzugefügt, die als Selektionsmarker fungieren. Das SOC-Medium, das für eine Transformation benötigt wurde, wurde einer 20 -minütigen Autoklavierung unterzogen und bei $121^{\circ} \mathrm{C}$ mit $20 \mathrm{mM}$ steril gefilterter Glukose versetzt.

\subsubsection{Geräte und Verbrauchsmaterialien}

Die Geräte und Verbrauchsmaterialien, die in dieser Arbeit verwendet wurden, sind in den jeweiligen Kapiteln angeführt. Die Verbrauchsmaterialien sind auf folgende Firmen zurückzuführen: Nunc (Roskilde, Dänemark), Carl Roth (Karlsruhe), Eppendorf (Hamburg), Greiner Bio-One (Frickenhausen), PEQLAP (Erlangen), Sarstedt (Nümbrecht), B. Braun AG (Melsungen), Biometra (Göttingen), Thermo-Fisher (Dreieich), VWR (Darmstadt).

\subsection{Methoden}

\subsubsection{Zellkulturmethoden}

Kultivierung von Säugerzellen und deren Behandlung

In dieser Arbeit wurden HeLa-S3-Zellen und U3A-zellen verwendet. Alle Zellkulturarbeiten wurden aseptisch unter mikrobiologischen Sicherheitswerkbänken (Herasafe K2, Thermo Scientific) durchgeführt. Die Zellkultivierung erfolgte in einer mit Wasser- 
dampf gesättigten $5 \%$ igen $\mathrm{CO}_{2}$-Atmosphäre bei $37^{\circ} \mathrm{C}$ in $75 \mathrm{~cm}^{2}$-Zellkulturflaschen (Cellstar, Greiner Bio-One) im Brutschrank (Heraeus, Thermo Scientific). Das Vollmedium der U3A-Zellen bestand aus Dulbeccos modifiziertem Eagle-Medium (DMEM, Biochrom, Berlin) supplementiert mit 10\% fetalem Kälberserum (FBS) (Biochrom), $1 \%$ Penicillin/Streptomycin (PAA, Pasching) und 0,04 $\mu \mathrm{g} / \mathrm{ml}$ Puromycin (Sigma-Aldrich). Als Vollmedium für die HeLa-S3-Zellen wurde Quantum $101 \mathrm{HeLa}-$ Medium (PAA) mit 1\% Penicillin/Streptomycin (PAA) verwendet.

Alle 2-3 Tage erfolgte das Passagieren der konfluenten Zellen für die Erhaltungskultur. Die Zellen wurden einmalig mit DPBS (Gibco) gewaschen und darauffolgend mit einer Trypsin/EDTA-Lösung (0,05\% Trypsin, 0,2 g/l EDTA, Biochrom) vom Flaschenboden der Zellkulturflasche gelöst. Durch Zugabe von serumhaltigem Vollmedium wurde die Trypsinreaktion gestoppt, nachdem sie kurzzeitig bei $37^{\circ} \mathrm{C}$ im Brutschrank inkubiert wurde. Im Verdünnungsverhältnis von 1:4 bis 1:6 wurden die Zellen zur Erhaltung der Kultur ausplattiert.

Bei einer Konfluenz von ca. 70\% war das Einfrieren der Zellen möglich. Sie wurden trypsiniert und in PBS aufgenommen. Anschließend folgte eine 10-minütige Zentrifugation bei $1000 \mathrm{rpm}$ bei $20^{\circ} \mathrm{C}$ (Centrifuge $5415 \mathrm{R}$, Eppendorf) und eine Aufnahme des Zentrifugats einer Zellkulturflasche von $75 \mathrm{~cm}^{2}$ in $1 \mathrm{ml}$ Einfriermedium (20\% FBS, $10 \%$ Dimethylsulfoxid in DMEM). Die resuspendierten Zellen wurden in GefriergefäBe (Nalgene, Heidelberg) gefüllt und mit Isopropanol (Carl Roth) über Nacht durch langsames Senken der Temperatur und unter Verwendung von DMSO auf eine Lagerungstemperatur von $-80^{\circ} \mathrm{C}$ heruntergekühlt. Auch die Lagerung erfolgte bei $-80^{\circ} \mathrm{C}$, wobei sie ebenfalls in flüssigem Stickstoff möglich gewesen wäre.

Im $37^{\circ} \mathrm{C}$ warmen Wasserbad erfolgte das rasche Wiederauftauen der eingefrorenen Zellen mit anschließender Resuspension in dem jeweiligen Vollmedium. Der Überstand wurde nach 5 -minütiger Zentrifugation bei $1000 \mathrm{rpm}$ und $20^{\circ} \mathrm{C}$ verworfen. Das Zellpellet konnte daraufhin im Vollmedium resuspendiert und die Zellen in Kultur genommen werden.

\subsubsection{Transfektion von Säugerzellen}

Um den Transfer von Plasmid-DNA in die humanen Zelllinien HeLa-S3 und U3A ermöglichen zu können, wurde das Transfektionsreagenz MegaTran 1.0 (Origene, Rockville, USA) verwendet. Für die Transfektion nach Herstellerangaben wurden bei einer 6-Loch-Platte pro Loch 1,6 $\mu$ g Plasmid-DNA eingesetzt. Für ein Loch einer 48- 
Loch-Platte wurden $0,25 \mu \mathrm{g}$ DNA und für jede Kammer eines 8-KammerObjekkträgers 0,1 $\mu \mathrm{g}$ DNA veranschlagt. Zu der Plasmid-DNA wurden $150 \mathrm{mM} \mathrm{NaCl}$ Lösung zur Verdünnung hinzugegeben und nach Vervollständigung des Transfektionsansatzes mit MegaTran für $10 \mathrm{sec}$ gevortext. Anschließend wurde der Ansatz für 10 min bei Raumtemperatur (RT) inkubiert und danach auf die sich im Medium befindlichen Zellen gegeben. 16 bis $20 \mathrm{~h}$ nach Transfektion wurden die Zellen analysiert und weiterverarbeitet.

\subsubsection{Behandlung von Zellen mit Zytokinen und Inhibitoren}

Bei der Verwendung von Inhibitoren und Zytokinen wurden diese jeweils mit dem dazugehörigen Zellkulturmedium verdünnt. Anschließend wurde die benötigte Menge an Medium auf die Zellen gegeben. Im Regelfall wurden für eine IFNY-Stimulation $10 \mathrm{ng} / \mathrm{ml}$ humanes, rekombinantes IFNy (Biomol) und für die StaurosporinBehandlung $1 \mu \mathrm{M}$ Staurosporin (Sigma-Aldrich) eingesetzt. Tyrosin-Phosphatasen konnten durch die Behandlung der Zellen mit 0,8 $\mathrm{mM}$ Vanadat und $0,2 \mathrm{mM} \mathrm{H}_{2} \mathrm{O}_{2}$ gehemmt werden. Für das Ansetzen einer $0,8 \mathrm{M} \mathrm{Na}_{3} \mathrm{VO}_{4}$-Stammlösung in $\mathrm{H}_{2} \mathrm{O}$ mit einem pH-Wert von 10 wurde die Lösung mehrfach erwärmt.

\subsubsection{Mutagenese}

Nach Herstellervorgaben wurden STAT1-kodierte Plasmide mit dem QuikChange II Site-Directed-Mutagenesis-Kit punktmutiert. Der Reaktionsansatz der PCR enthielt $50 \mathrm{ng}$ Matrizen-DNA, $5 \mu \mathrm{l}$ 10x Reaktionspuffer, $125 \mathrm{ng}$ komplementäre Primer, 2,5 Einheiten PfuTurbo DNA-Polymerase und $1 \mu \mathrm{l}$ dNTP-Mix. Der Ansatz wurde mit $\mathrm{H}_{2} \mathrm{O}$ auf $50 \mu$ lerweitert. Das PCR-Protokoll umfasste 16 Zyklen, wobei jeder Zyklus aus drei Schritten bestand: Denaturierung für $30 \mathrm{sec}$ bei $95^{\circ} \mathrm{C}$, Annealing für $1 \mathrm{~min}$ bei $55^{\circ} \mathrm{C}$ und Elongation für $14 \mathrm{~min}$ bei $68^{\circ} \mathrm{C}$. Es erfolgte ein $D p n$ I-Verdau für $1 \mathrm{~h}$ bei $37^{\circ} \mathrm{C}$ zur Entfernung der methylierten, parentalen DNA. Dazu wurden 10 Einheiten Dpn I-Restriktionsenzym zum PCR-Amplifikat pipettiert.

\subsubsection{Transformation von Plasmid-DNA in kompetente Bakterien}

Kompetente E. coli DH5a-Bakterien (100 $\mu \mathrm{l})$ bzw. E. coli XL1-Blue superkompetente Zellen $(50 \mu \mathrm{l})$ wurden allmählich auf Eis aufgetaut, mit $10 \mathrm{ng}$ Plasmid-DNA bzw. $1 \mu \mathrm{l}$ des Mutagenese-Ansatzes versetzt und $30 \mathrm{~min}$ auf Eis inkubiert. Darauffolgend wurde die Bakteriensuspension einem im Falle der E. coli DH5a-Bakterien 30-sekün- 
digen Hitzeschock und einem 45-sekündigen Hitzeschock im Falle der E.coli XL1Blue-Bakterien bei $42^{\circ} \mathrm{C}$ unterzogen. Danach folgte eine 2-minütige Inkubation auf Eis und eine Überführung der Bakterien in 500-1000 $\mu \mathrm{l}$ vorgewärmtes SOC-Medium. Nach einer erneuten einstündigen Inkubation bei $225 \mathrm{rpm}$ und $37^{\circ} \mathrm{C}$ wurden $250 \mu \mathrm{l}$ der Bakterienkultur auf LB-Agarplatten mit einem entsprechenden Antibiotikum ausplattiert und bei $37^{\circ} \mathrm{C}$ über Nacht inkubiert.

\subsubsection{Isolation von Plasmid-DNA aus Bakterien}

Um eine analytische Präparation von Plasmid-DNA durchzuführen, wurde eine einzelne, zuvor transformierte Bakterienkolonie gepickt, in $2 \mathrm{ml}$ LB-Medium mit einem Selektionsmarker inokuliert und für $7 \mathrm{~h}$ bei $225 \mathrm{rpm}$ und $37^{\circ} \mathrm{C}$ inkubiert. Nach beendeter Inkubationszeit wurde der Inhalt in ein Reaktionsgefäß überführt und durch 5minütiges Zentrifugieren mit 13.000 rpm bei RT niedergeschlagen. Um eine Sequenzierung der mutierten Plasmid-DNA durchzuführen, wurde diese nach Herstelleranleitung mit dem peqGold Plasmid Miniprep Kit (PEQLAP Biotechnologie) aus dem Zellpellet isoliert. Es wurde ein präparativer Ansatz gewählt, um große Mengen reiner Plasmid-DNA isolieren zu können. Dazu wurden 150 ml LB-Medium mit dazugehörigem Selektionsantibiotikum versetzt, um es mit einer einzelnen, transformierten Bakterienkolonie zu inokulieren. Die Inkubation geschah bei $225 \mathrm{rpm}$ und $37^{\circ} \mathrm{C}$ über Nacht. Darauffolgend wurde die Bakteriensuspension bei RT und $6000 \mathrm{~g}$ für $15 \mathrm{~min}$ zentrifugiert und die Plasmid-DNA durch Verwendung des QIAGEN Plasmid-Maxi-Kit (Qiagen, Hilden) isoliert. Mit $\mathrm{H}_{2} \mathrm{O}$ wurde die DNA eluiert. Es folgte die Konzentrationsbestimmung und eine Verdünnung mit $\mathrm{H}_{2} \mathrm{O}$ auf $1 \mu \mathrm{g} / \mu \mathrm{l}$ sowie die Lagerung bei einer Temperatur von $-20^{\circ} \mathrm{C}$.

\subsubsection{Konzentrationsbestimmung von DNA}

Mithilfe des Photometers BioPhotometer Plus (Eppendorf) wurde die Konzentration der DNA bei einer Wellenlänge von $\lambda=260 \mathrm{~nm}$ mit einer $70 \mu$-UV-Küvette (Brand, Wertheim) photometrisch analysiert. Die Konzentration der Proben wurde mit einer Formel (DNA-Konzentration $[\mu \mathrm{g} / \mathrm{ml}]=\mathrm{A} 260 \times 50 \times$ Verdünnungsfaktor) bestimmt. Eine Verunreinigung der Probe wurde durch die Messung der Absorption bei $\lambda=280 \mathrm{~nm}$ und durch die Bildung des Quotienten A260/A280 untersucht und konnte 
entweder nachgewiesen oder ausgeschlossen werden. Bei einem Wert von 1,8 liegt keine Verunreinigung vor.

\subsubsection{Sequenzierung}

Um die eingefügten Punktmutationen verifizieren zu können, wurde eine Sequenzierung der Plasmid-DNA von SeqLabSequence Laboratories (Göttingen) durchgeführt. Dazu wurden zu 700 ng Plasmid-DNA in ein Gesamtvolumen von $7 \mu \mathrm{l} 20$ pM eines entsprechenden Sequenzierprimers beigefügt.

\subsubsection{Herstellung von Zellextrakten}

Für unterschiedliche Assays wie Western Blot, In-vivo-Dephosphorylierung und Gelshift-Experimente wurden Gesamtzellextrakte eingesetzt. Die Zellen wurden in 6Loch-Platten nach Transfektion und entsprechender Stimulation auf Eis aufbereitet. Sie wurden mit PBS gewaschen und darauffolgend pro Loch mit $50 \mu \mathrm{l}$ auf Eis gelagertem zytosolischem Extraktionspuffer (1 mM EDTA, $10 \mathrm{mM} \mathrm{KCl,} \mathrm{pH} \mathrm{7,4,} \mathrm{10 \%} \mathrm{Gly-}$ cerol, $20 \mathrm{mM}$ Hepes, 0,1 mM Natrium-ortho-Vanadat $\left(\mathrm{Na}_{3} \mathrm{VO}_{4}\right)$ ) lysiert. Direkt vor Gebrauch des Puffers wurden 0,4 mM Pefabloc, 0,1\% IGEPAL-CA-360, 3 mM DTT und Complete-Mini-Protease-Inhibitoren hinzugegeben. Nach der Inkubation wurden die Zellen mit einem Zellschaber aus den Wells heruntergeschabt, die Lysate in $1,5 \mathrm{ml}$ Reaktionsgefäße pipettiert und in der Eppendorf-Tischzentrifuge bei $4^{\circ} \mathrm{C}$ für $10 \mathrm{sec}$ bei $13.000 \mathrm{rpm}$ zentrifugiert. Es entstanden ein Zellpellett und zytosolische Extrakte, die als Überstände in neue Reaktionsgefäße überführt wurden. Die Überstände wurden für $5 \mathrm{~min}$ bei $13.000 \mathrm{rpm}$ und $4^{\circ} \mathrm{C}$ zentrifugiert und für die weitere Verarbeitung auf Eis gelagert. Die Niederschläge aus dem ersten Zentrifugationsschritt wurden in $50 \mu \mathrm{l}$ nukleärem Extraktionspuffer $(420 \mathrm{mM} \mathrm{KCl}, 1 \mathrm{mM}$ EDTA, $20 \mathrm{mM}$ Hepes, 20\% Glycerol, 0,1 $\mathrm{mM} \mathrm{Na}_{3} \mathrm{VO}_{4}, \mathrm{pH}$ 7,4) resuspendiert, für 30 min auf Eis inkubiert und wiederholt für $15 \mathrm{~min}$ bei $13.000 \mathrm{rpm}$ und $4^{\circ} \mathrm{C}$ zentrifugiert. Ebenfalls direkt vor Gebrauch wurden auch dem nukleären Extraktionspuffer 3 mM DTT, Complete-Mini-Protease-Inhibitoren und 0,4 mM Pefabloc zugesetzt. Bei den entstandenen Überständen handelte es sich um die nukleären Zellextrakte. Diese konnten entweder mit gleichen Mengen an zytosolischen Extrakten vermischt werden, um als Gesamtzellextrakte zu fungieren oder bei $-80^{\circ} \mathrm{C}$ für eine Weiterverarbeitung eingefroren zu werden. Um Western-Blot-Analysen durchführen zu können, wurde den vereinigten Extrakten 6xSDS-Probenpuffer (8\% Natriumlaurylsulfat (SDS), 0,04\% 
Bromphenol-Blau, $350 \mathrm{mM}$ Tris-HCl, 30\% Glycerol, 10\% $\beta$-Mercaptoethanol, pH 6,8) beigefügt. Die Proben wurden für 3 min bei $95^{\circ} \mathrm{C}$ erhitzt und bei $-20^{\circ} \mathrm{C}$ aufbewahrt. Für Dephosphorylierungsversuche wurden die Extrakte ohne die Zugabe von SDSProbenpuffer bei $-80^{\circ} \mathrm{C}$ gelagert.

\subsubsection{SDS-Polyacrylamid-Gelelektrophorese (SDS-PAGE)}

Mithilfe der SDS-Polyacrylamid-Gelelektrophorese wurden Proteine, die zuvor durch Hitze denaturiert wurden, ihrer Größe nach in einem vertikalen Elektrophoresesystem (Minigel-Twin, Biometra) mit einer Spannung von $11 \mathrm{~mA} / \mathrm{Gel}$ in SDS-Laufpuffer (25mM Tris-Base, 192 mM Glycin, 0,1\% SDS, pH 8,6) aufgetrennt. Als Trägermaterial wurde für die Gelelektrophorese ein Polyacrylamidgel angesetzt, das aus einem Trenngel und einem Sammelgel besteht. Das Trenngel setzte sich aus 10\% (v/v) Rotiphorese Gel 30 (Acrylamid/Bisacrylamid 37), 0,03\% APS, 0,16\% TEMED, 4x Trenngelpuffer $(1,5 \mathrm{M}$ Tris- $\mathrm{HCl}, 0,4 \% \mathrm{SDS}, \mathrm{pH} 8,8)$ zusammen. Das Sammelgel bestand aus 5\% Rotiphorese Gel 30, 0,06\% APS, 0,2\% TEMED und 4x Sammelgelpuffer (0,5 M Tris- $\mathrm{HCl}, 0,4 \%$ SDS, pH 6,8). Um ein Polyacrylamidgel zu gießen, wurde zuerst das Trenngel zwischen zwei Glasplatten gegeben, die durch einen Gummirahmen leicht voneinander getrennt waren. Für einen definierten Abschluss des Gels wurde das Trenngel mit Isopropanol bedeckt. Nach abgeschlossener Polymerisation des Gels wurde das Isopropanol wieder abgenommen und das Sammelgel auf das Trenngel gegeben. Mit einem Plastikkamm konnten die Geltaschen modelliert werden. Gesamtzellextrakte wurden dem Gefrierschrank bei $-20^{\circ} \mathrm{C}$ entnommen und für $3 \mathrm{~min}$ bei $95^{\circ} \mathrm{C}$ im Heizblock denaturiert. Darauffolgend wurden 10-20 $\mu \mathrm{l}$ der Zellextrakte in die vorgefertigten Geltaschen appliziert, wobei sowohl in der ersten als auch in der letzten Tasche ca. $7 \mu$ SDS-Puffer als Laufhilfe aufgetragen wurden.

\subsubsection{Immunchemische Proteindetektion mittels Western Blot}

Die Proteine, die im Gel durch SDS-Polyacrylamidgelelektrophorese aufgetrennt wurden, ließen sich auf eine Polyvinylidenfluorid-Membran (PVDF-Membran) (Millipore, Schwalbach/Ts.) übertragen. Das elektrische Transferverfahren erfolgte mit dem Fastblot B44 (Biometra) nach der Semi-Dry-Methode. Am Anfang wurde die zuvor hydrophobe Membran für $5 \mathrm{~min}$ in Methanol (Sigma-Aldrich) aktiviert. Darauf folgte eine zweimalige Inkubation auf dem Schüttler (Duomax) für je $15 \mathrm{~min}$ in Transferpuffer (25 mM Tris-Base, 150 mM Glycin, 10\% Methanol, pH 8). Nach einer Transfer- 
dauer von 90 min bei 80 mA pro Blot wurde die Membran 5 min mit TBS-T (137 mM $\mathrm{NaCl}, 10 \mathrm{mM}$ Tris-HCl, 0,05\% Tween-20, $\mathrm{pH} 7,4)$ gewaschen und $1 \mathrm{~h}$ auf dem Duomax mit 4\% BSA (Albumin Fraktion V, Carl Roth) in TBS-T blockiert, wodurch freie Bindungsstellen der DNA abgesättigt werden konnten. Die erste Inkubation mit dem Primärantikörper wurde über Nacht bei $4^{\circ} \mathrm{C}$ auf dem Schüttler durchgeführt. Danach wurde der Primärantikörper entfernt und die Membran fünfmal für jeweils $5 \mathrm{~min}$ mit TBS-T gewaschen. Darauf erfolgte eine erneute einstündige Inkubation mit dem Sekundärantikörper bei RT auf dem Schüttler. Durch das LI-COR Odyssey Sa Imaging System (Biosciences, Bad Homburg) konnten darauffolgend die Proteine eruiert werden. Um die Membran erneut mit einem weiteren Primärantikörper exponieren zu können, wurde sie $1 \mathrm{~h}$ in einem $60^{\circ} \mathrm{C}$ heißen Wasserbad in einem Ablösepuffer (2\% SDS, 0,7\% $\beta$-Mercaptoethanol, $62,5 \mathrm{mM}$ Tris- $\mathrm{HCl}, \mathrm{pH} 6,8$ ) inkubiert. Somit konnten an die Membran gebundene Antikörper entfernt werden. Erneutes Waschen in 4 Zyklen mit TBS-T von je 15 min und einer einstündigen Blockierung mit $4 \%$ BSA in TBS-T ermöglichte es, die Membran wiederholt mit einem anderen Erstantikörper zu inkubieren. Nach 2,5 h wurde der letzte Primärantikörper in 5 Zyklen von je 5 min mit TBS-T von der Membran heruntergewaschen und ein letztes Mal ein Sekundärantikörper aufgetragen. Darauf folgte ein erneutes Waschen in 5 Zyklen à 5 min mit TBST und einmal mit TBS. Anschließend konnte die Membran im LI-COR-Lesegerät eingelesen werden.

\subsubsection{Gelshift-Assays (Electrophoretic Mobility Shift Assay, EMSA)}

In Gelshift-Experimenten wurden Protein-DNA-Wechselwirkungen nachgewiesen (Begitt et al. 2000). Da STAT1-Proteine eine Verbindung mit komplementären Oligonukleotid-Sonden eingehen, wurden verschiedene dieser Sonden benutzt, die mit einer singulären (M67), einer zweifachen (2xGAS), einer singulären gefolgt von einer degenerierten GAS-Stelle (GAS-nonGAS) oder zwei aufeinander folgenden degenerierten GAS-Stellen (2xnonGAS) bestückt waren. Um diese Sonden radioaktiv markieren zu können und somit eine autoradiographische Detektion der Banden zu gewährleisten, wurden die überhängenden Enden der zuvor hybridisierten Oligonukleotide verwendet. Eine Hybridisierung stellt den ersten Schritt einer Sondenherstelllung dar. Hierzu fand eine 5 -minütige Inkubation bei $95^{\circ} \mathrm{C}$ in Oligo-Puffer $\left(10 \mathrm{mM} \mathrm{MgCl}_{2}\right.$, $50 \mathrm{mM} \mathrm{KCl}, 20 \mathrm{mM}$ Tris- $\mathrm{HCl}, \mathrm{pH}$ 7,5) statt. Darauf folgte bei einer Konzentration von $50 \mathrm{pM} / \mathrm{ml}$ je Oligonukleotid ein langsames Abkühlen auf RT. Für eine weitere Ver- 
wendung wurden die Nukleotide bei $-20^{\circ} \mathrm{C}$ gelagert. Die 5 -Überhänge der Oligonukleotide wurden mit radioaktiv markierten $\alpha-\left[{ }^{33} \mathrm{P}\right]-$ Nukleotiden durch das KlenowFragment der E.coli-DNA-Polymerase I (New England Biolabs, Frankfurt am Main) aufgefüllt. Dazu wurden $0,1 \mathrm{ng}$ der Oligonukleotide und jeweils $8 \mu \mathrm{l}$ des $\left[{ }^{33} \mathrm{P}\right]-$ markierten Desoxythymidintriphosphat (dTTP) zusammen mit 5 Einheiten des Klenow-Enzyms in $5 \mu \mathrm{l}$ 10x Eco-Pol-Puffer (New England Biolabs) für 25 min bei RT inkubiert. Beendet wurde die Markierungsreaktion durch die Zugabe von $1 \mu \mathrm{l} 0,5 \mathrm{M}$ EDTA-Lösung. Nach 2-minütigem Zentrifugieren bei RT und $700 \mathrm{~g}$ über IllustraMicroSpin-G-25-Säulen (GE Healthcare, München) wurden anschließend freie Nukleotide abgetrennt.

Eine EMSA-Reaktion wurde mit 4,5 $\mu \mathrm{l}$ Gesamtzellextrakten, $0,2 \mu \mathrm{l}$ der radioaktiv markierten Sonde, $1 \mu \mathrm{l}$ einer Poly-Desoxyinosid-Desoxycytidin-Lösung (Poly-dldC, $2 \mathrm{mg} / \mathrm{ml}$ ), 2,5 $\mu \mathrm{l} 5 \mathrm{x}$ Shift-Puffer (100 mM Hepes, pH 7,9, 20\% Ficoll, $5 \mathrm{mM} \mathrm{MgCl}$, 200 mM KCl, 0,5 mM 1,2-Bis-(2-aminoethoxyethan)-N,N,N',N'-Tetraessigsäure (EGTA), 2,5 mM EDTA), $13 \mu \mathrm{l}$ DTT (100 mM) und 3,5 $\mu \mathrm{H}_{2} \mathrm{O}$ für $15 \mathrm{~min}$ bei RT inkubiert. Danach konnte das denaturierende EMSA-Polyacrylamidgel beladen werden. Wurden weniger als 4,5 $\mu$ Z Zellextrakte eingesetzt, wurde die Probe mit PBS oder mit untransfiziertem U3A-Gesamtzellextrakt auf $13 \mu \mathrm{l}$ aufgefüllt. Bezogen auf den jeweiligen Versuch wurden Kompetitionen mit unmarkierter DNA durchgeführt. Zu dem kompetitiven Ansatz wurden $2 \mu$ leiner nicht radioaktiven M67-Sonde in 750-fachem molaren Überschuss hinzugegeben und bei RT für die angegebenen Zeiträume inkubiert. Supershift-Reaktionen enthielten je Reaktionsansatz $1,3 \mu \mathrm{l}$ polyklonalen STAT1-Antikörper C-24 oder STAT3-Antikörper. Somit konnte die Identifikation des STAT1-Proteins bestätigt werden. Die gebildeten Protein-DNA-Komplexe wurden in nativen, äquilibrierten $4,8 \%$-igen Polyacrylamid-Gelen bei $400 \mathrm{~V}$ und $4^{\circ} \mathrm{C}$ und mit $0,25 x$ TBE-Puffer als Laufpuffer für ca. 2,5 h aufgetrennt. Die Gelherstellung erfolgte durch die Zusammenführung einer Acrylamid/Bisacrylamid (29:1)-Lösung (12 ml Rotiphorese Gel 40), $84 \mathrm{ml} \mathrm{H} \mathrm{H}_{2} \mathrm{O}, 2 \mathrm{ml}$ 10\% APS und $100 \mu \mathrm{l}$ 0,1\% TEMED in 0,25x TBE. Nach Abschluss der Gelelektrophorese wurde das Gel für ca. 30 min auf WhatmanPapier (Albet Lab Science, Dassel) vakuumgetrocknet, über Nacht bei RT auf einer Phospho-Imager-Folie exponiert und schließlich mithilfe des Fujifilm FLA-5100 Scanners (Fuji, Düsseldorf) eingescannt, um die gebundene Radioaktivität detektieren zu können. Die Daten wurden anschließend mit dem Softwareprogramm Corel-Draw (Corel) ausgewertet. 


\subsubsection{Fluoreszenzmikroskopische Analyse}

Für die fluoreszenzmikroskopischen Analysen wurden Zellen auf LabTek-ChamberSlides mit acht Kammern (Thermo Fisher Scientific, Langenselbold) kultiviert und mit STAT1-GFP-Derivaten und STAT1-WT-GFP transfiziert. GFP-markierte STAT1-exprimierende Zellen wurden 16-24 h nach der Transfektion, wie jeweils angegeben, stimuliert und darauffolgend bei RT für 15 min mit 4\% Formaldehyd in DPBS fixiert. Nach zweimaligem Waschen mit PBS und einmaligem Waschen mit $\mathrm{H}_{2} \mathrm{O}$ wurden die Zellen für 10 min bei RT auf dem Rüttler mit Hoechst $33258(5 \mu \mathrm{g} / \mathrm{ml}$ in PBS) gefärbt und weitere Waschungen mit PBS und $\mathrm{H}_{2} \mathrm{O}$ durchgeführt. Danach wurden die Objektträger mit ein paar Tropfen Fluoromount-G-Eindeckmedium (Southern Biotech, Birmingham, USA) versehen und eingedeckt. Die Objektträger konnten nun bei $-4^{\circ} \mathrm{C}$ lichtgeschützt aufbewahrt werden.

Um eine immunzytochemische Detektion von unmarkiertem STAT1 durchzuführen, wurden die Zellen 16-24 h nach der Transfektion, wie jeweils angegeben, stimuliert und für 10 min in gekühltem Methanol bei $-20^{\circ} \mathrm{C}$ fixiert. Durch 20 -minütige Behandlung bei RT mit 1\% Triton-X-100 in PBS wurden die Zellen permeabilisiert und anschließend für 45 min mit 25\% FBS in PBS zur Absättigung unspezifischer Bindungsstellen inkubiert. Danach erfolgte eine Inkubation von 45 min unter Schütteln mit AntiSTAT1 C-24 als Erstantikörper in einer Verdünnung von 1:1000 mit 25\% FBS in PBS. Nach dreimaligem Waschen mit PBS wurde eine 45-minütige Inkubation unter Schütteln mit einem Cy3-gekoppelten Anti-Kaninchen-IgG aus Ziege in 500-facher Verdünnung (25\% FBS in PBS) durchgeführt. Es folgten drei Waschschritte mit PBS, anschließend eine Hoechst-Färbung und die Eindeckung der Präparate mit Fluoromount-G-Eindeckmedium.

Mit dem Mikroskop DM5000B (Leica, Wetzlar) wurden die fluoreszenzmikroskopischen Analysen erhoben. Mit einer CCD-Kamera wurden fluoreszenzmikroskopische Aufnahmen von den Proben angefertigt und mithilfe der QWin-Software (Leica) bearbeitet. Bilder der GFP-gekoppelten Fusionsproteine wurden bei einer Anregungswellenlänge von $480 \mathrm{~nm}$ aufgenommen. Für die Aufnahmen Cy3-gekopppelter Antikörper betrug die Wellenlänge $550 \mathrm{~nm}$ und für die der Hoechst-gefärbten Zellkerne $280 \mathrm{~nm}$. Mit dem Grafikprogramm CorelDraw (Corel) erfolgte die weitere Bearbeitung und Dokumentation der digitalen Daten. 


\subsubsection{Reportergen-Assay}

Um die transkriptionelle Aktivität von STAT1-WT und der STAT1-Mutanten bestimmen zu können, wurde ein mit drei IFNY-sensitiven Ly6E-STAT-Bindestellen bestücktes, luciferasekodierendes Reportergenkonstrukt (Wen et al. 1995) verwendet. Zusätzlich wurde zur Quantifizierung ein konstitutiv exprimierter $\beta$-Galactosidase-Reporter in die Zellen kotransfiziert, um die $\beta$-Galactosidaseaktivität in den gleichen Extrakten zu messen. U3A-Zellen wurden pro Loch einer 48er-Loch-Platte mit $250 \mathrm{ng}$ des entsprechenden STAT1-kodierenden Plasmids, $200 \mathrm{ng} \quad \beta$-GalactosidaseReporterplasmid und $70 \mathrm{ng} 3 x \mathrm{xy} 6 \mathrm{E}-\mathrm{Plasmid}$ transfiziert. 16-24 h nach Transfektion wurden die Zellen entweder für $6 \mathrm{~h}$ mit IFNy im Vollmedium inkubiert oder sie blieben unbehandelt. Es wurden jeweils sechsfache Bestimmungen durchgeführt. Im Anschluss wurde das Medium abgenommen und einmal mit PBS gewaschen. Für die darauffolgende Zelllyse wurde der bei $4^{\circ} \mathrm{C}$ gelagerte Triton-Glycylglycin-Lysepuffer (25 mM Glycylglycin, pH 7,8, 1\% Triton X-100, $15 \mathrm{mM} \mathrm{MgSO}_{4}, 4 \mathrm{mM}$ EGTA) mit $3 \mathrm{mM}$ DTT, 0,4 mM Pefabloc und Complete-Mini-Protease-Inhibitoren versetzt. Pro Loch wurden die Zellen mit $100 \mu \mathrm{l}$ des komplementierten Triton-GlycylglycinLysepuffers für 15 min bei RT inkubiert und die Lysate dann unter Resuspension in $1,5 \mathrm{ml}$ Reaktionsgefäße überführt. Nach 15-minütiger Zentrifugation bei $13.000 \mathrm{rpm}$ und $4^{\circ} \mathrm{C}$ wurden $20 \mu \mathrm{l}$ der Überstände in eine weiße 96er Immuno-Platte pipettiert und somit die Luciferase-Aktivität durch Zugabe von $50 \mu$ l Substratlösung des Luciferase-Assay-Systems im Luminometer Centro-LB-960 (Berthold Technologies, Bad Wildbad) gemessen.

Zur Bestimmung der $\beta$-Galactosidaseaktivität wurden erneut $20 \mu \mathrm{l}$ des Lysats mit $211 \mu \mathrm{l}$ Natriumphosphat-Puffer $(100 \mathrm{mM}, \mathrm{pH} 7,2), 4 \mathrm{mg} / \mathrm{ml}$ in $100 \mathrm{mM}$ Natriumphosphat-Puffer, und $3 \mu \mathrm{l}$ einer 100x Magnesium-Lösung (100 mM MgCl $2,4,5 \mathrm{mM} \beta$ Mercapto-ethanol) und $66 \mu$ l Ortho-Nitrophenyl- $\beta$-D-Galactopyranosid (ONPG) versetzt. Die Farbreaktion im Sinne einer Verfärbung ins Gelbliche nach ca. 20 min wurde durch Zugabe von $500 \mu$ einer 0,5 M Natriumcarbonat-Lösung $\left(\mathrm{Na}_{2} \mathrm{CO}_{3}\right)$ gestoppt und die $\beta$-Galactosidaseaktivität bei einer Wellenlänge von $420 \mathrm{~nm}$ mithilfe des Infinite 200 PRO (Tecan, Männedorf, Schweiz) gemessen. Der Quotient aus dem Messwert der Luciferaseaktivität wurde zur Normierung durch den Messwert der $\beta$ Galactosidaseaktivität gebildet. Mittelwerte sowie Standardabweichungen wurden mit den Software-Programmen Excel (Microsoft Deutschland, Unterschleißheim) und Sigmablot (Systat Software, Erkrath) berechnet. 


\subsubsection{RNA-Isolation}

In 6-Loch-Multischalen wurden U3A-Zellen kultiviert und mit den jeweiligen STAT1Expressionsplasmiden im Vektor pcDNA3.1 transfiziert. 24 h nach erfolgter Transfektion wurden die Zellen über Nacht in Dulbecco's modifiziertem Eagle-Medium (DMEM), ergänzt mit 1\% fetalem Kälberserum (FBS), kultiviert und dann entweder $6 \mathrm{~h}$ bei $37^{\circ} \mathrm{C}$ mit $10 \mathrm{ng} / \mathrm{ml}$ IFNy im Vollmedium stimuliert oder unbehandelt belassen. Nach Absaugen des Mediums erfolgte die RNA-Isolation nach den Herstellerangaben des peqGold-Total-RNA-Kits (PEQLAB). Mit $50 \mu \mathrm{L}$ RNase-freiem Wasser wurde die RNA eluiert und sofort zur cDNA-Synthese eingesetzt. Eine Lagerung bei $-80^{\circ} \mathrm{C}$ war jedoch ebenfalls möglich.

\subsubsection{7 cDNA-Herstellung}

Um die RNA durch reverse Transkriptase in komplementäre DNA (cDNA) umzuschreiben, wurde das Verso-cDNA-Kit (Thermo Fisher Scientific) nach Herstellerangaben angewendet. In diesem System ist die Verso-Reverse-Transcriptase enthalten. Als Primer wurden die Anchored-oligo-dT-Primer verwendet. Für einen $20 \mu \mathrm{l}-$ Ansatz wurden $8 \mu \mathrm{I}$ RNA eingesetzt. Die Proben wurden bei $-20^{\circ} \mathrm{C}$ aufbewahrt.

\subsubsection{Real-time PCR}

In einem Reaktionsvolumen von $19 \mu$ l wurde die real-time PCR nach den Herstellerangaben des Absolute-Blue-QPCR-SYBR-Green Mix (Thermo Scientific) durchgeführt. Pro Reaktion wurde $1 \mu \mathrm{l}$ cDNA eingesetzt und jeweils Doppelbestimmungen vorgenommen. Einer Enzymaktivierung bzw. einer initialen Denaturierungsphase von 15 min bei $95^{\circ} \mathrm{C}$ folgten 45 Zyklen als Bestandteil des Protokolls der real-time PCR. Eine Denaturierung von $15 \mathrm{sec}$ bei $95^{\circ} \mathrm{C}$, eine Hybridisierung für $30 \mathrm{sec}$ bei $55^{\circ} \mathrm{C}$ und eine Verlängerung für $30 \mathrm{sec}$ bei $72^{\circ} \mathrm{C}$ machten einen Zyklus aus. Am Ende wurde eine Schmelzkurve gemessen, um die Reinheit der PCR-Produkte zu bestimmen. Mit dem Softwareprogramm Realplex (Eppendorf) wurden die Messdaten analysiert und mithilfe der Programme SigmaPlot und Excel weiter bearbeitet.

\subsubsection{Statistik}

Bei den in mindestens drei unabhängigen Transfektionen durchgeführten Genexpressionsanalysen wurde die statistische Signifikanz mithilfe des $t$-Tests berech- 
net. Hierzu wurden sechsfache Bestimmungen bei den Reportergen-Assays und Doppelbestimmungen bei der real-time PCR vorgenommen. Anschließend wurden die Mittelwerte und Standardabweichungen der Ergebnisse mittels Microsoft Office Excel und SigmaPlot ausgewertet. Ein $p$-Wert $<0,05$ wurde als statistisch signifikant angesehen. 


\section{Ergebnisse}

In dieser Arbeit wurden durch die Durchführung von Punktmutationen in der DNABindedomäne von STAT1 drei Mutanten generiert, um diese im Weiteren hinsichtlich ihrer phänotypischen Eigenschaften im interferonabhängigen Signalweg zu charakterisieren. Dies geschah durch den Austausch von drei durch Sequenzvergleiche innerhalb der sieben Mitglieder der humanen STAT-Familie identifizierten, konservierten Aminosäureresten in der besagten Domäne (Abb. 5). An den Positionen 359 und 361 wurde jeweils ein Lysinrest und an der Position 367 ein Asparaginsäurerest zu Alanin mutiert. Diese Lysin- und Asparaginsäurereste liegen an der Oberfläche des Proteins, wie die Untersuchung der Kristallstruktur ergab. Die Ladung ihrer funktionellen Gruppe ist entweder positiv beziehungsweise negativ. Das besondere Interesse lag auf möglichen Abweichungen der Tyrosin-Phosphorylierung sowie der transkriptionellen Aktivierung in den Mutanten. Es soll die Hypothese getestet werden, dass die untersuchten Aminosäurereste an der Konformationsänderung zwischen paralleler und antiparalleler Ausrichtung beteiligt sind. 


\begin{tabular}{l|l|l|l|l|l|l|l|l|l|l|l|l|l|l|l} 
STAT1 & 358 & $\mathrm{~L}$ & $\mathrm{~K}$ & & & & $\mathrm{~V}$ & $\mathrm{~K}$ & $\mathrm{~V}$ & $\mathrm{I}$ & $\mathrm{F}$ & $\mathrm{D}$ & $\mathrm{K}$ & $\mathrm{D}$ & 367 \\
\hline STAT2 & 357 & $\mathrm{~L}$ & $\mathrm{I}$ & & & & $\mathrm{V}$ & $\mathrm{E}$ & $\mathrm{V}$ & $\mathrm{S}$ & $\mathrm{I}$ & $\mathrm{D}$ & $\mathrm{R}$ & $\mathrm{N}$ & 366 \\
\hline STAT3 & 362 & $\mathrm{~L}$ & $\mathrm{~K}$ & & & & $\mathrm{I}$ & $\mathrm{K}$ & $\mathrm{V}$ & $\mathrm{C}$ & $\mathrm{I}$ & $\mathrm{D}$ & $\mathrm{K}$ & $\mathrm{D}$ & 371 \\
\hline STAT4 & 358 & $\mathrm{~V}$ & $\mathrm{~K}$ & & & & $\mathrm{~V}$ & $\mathrm{~K}$ & $\mathrm{~A}$ & $\mathrm{~S}$ & $\mathrm{I}$ & $\mathrm{D}$ & $\mathrm{K}$ & $\mathrm{N}$ & 367 \\
\hline STAT5a & 364 & $\mathrm{M}$ & $\mathrm{N}$ & $\mathrm{P}$ & $\mathrm{P}$ & $\mathrm{Q}$ & $\mathrm{V}$ & $\mathrm{K}$ & $\mathrm{A}$ & $\mathrm{T}$ & $\mathrm{I}$ & $\mathrm{I}$ & $\mathrm{S}$ & $\mathrm{E}$ & 377 \\
\hline STAT5b & 364 & $\mathrm{M}$ & $\mathrm{N}$ & $\mathrm{P}$ & $\mathrm{P}$ & $\mathrm{Q}$ & $\mathrm{V}$ & $\mathrm{K}$ & $\mathrm{A}$ & $\mathrm{T}$ & $\mathrm{I}$ & $\mathrm{I}$ & $\mathrm{S}$ & $\mathrm{E}$ & 377 \\
\hline STAT6 & 306 & $\mathrm{~A}$ & $\mathrm{~K}$ & $\mathrm{P}$ & $\mathrm{P}$ & $\mathrm{L}$ & $\mathrm{V}$ & $\mathrm{R}$ & $\mathrm{A}$ & $\mathrm{D}$ & $\mathrm{M}$ & $\mathrm{V}$ & $\mathrm{T}$ & $\mathrm{E}$ & 318
\end{tabular}

Abb. 5: Sequenzvergleich humaner STAT-Proteine. Der Sequenzvergleich aller humanen STAT-Proteine zeigt, dass der Grad der Konservierung nicht bei allen Mutanten gleichwertig vorhanden ist. An Position 359 bei STAT1 befindet sich ein Lysinrest, ebenso bei STAT3, STAT4 und STAT6. An Position 361 ist der Lysinrest höher konserviert. Nur STAT2 und STAT6 weisen andere Aminosäuren auf. An Position 367 von STAT1 befindet sich ein Asparaginsäurerest, der unter den humanen Mitgliedern dieser Proteinfamilie am wenigsten konserviert ist.

\subsection{Die STAT1-Mutanten K359A, K361A und D367A zeigen ein vergleichbares} Phosphorylierungsniveau wie das Wildtyp-Molekül

In einer Reihe von Western-Blot-Analysen wurde nach der Stimulation transient transfizierter Zellen mit IFNy die Phosphorylierung von STAT1-K359A sowie STAT1K361A und STAT1-D367A überprüft. Dies geschah stets im Vergleich zum WildtypMolekül. Durch Verwendung des Kinase-Inhibitors Staurosporin konnte zusätzlich die zeitabhängige Unterbrechung der STAT1-Phosphorylierung untersucht werden. Dafür bedurfte es einer Transfektion von HeLa-S3- bzw. U3A-Zellen mit pSTAT1-WT-GFPoder pSTAT1-GFP-Konstrukten, die für das Wildtyp-Molekül oder einer der drei verwendeten Mutanten kodierten. Für eine mögliche Detektion der In-vivoDephosphorylierung wurden die Zellen nach einer Stimulationsdauer von $45 \mathrm{~min}$ mit $10 \mathrm{ng} / \mathrm{ml}$ IFNy für verschiedene Zeitspannen mit $1 \mu \mathrm{M}$ Staurosporin inkubiert. Für die Detektion der Phosphorylierungsbanden wurde eine gelelektrophoretische Auftrennung der Gesamtzellextrakte sowie eine darauffolgende Verwendung eines PhosphoSTAT1-Antikörpers im Immunoblot-Verfahren vorgenommen. Um die Gesamtmenge von STAT1 bestimmen zu können, wurde die Western-Blot-Membran gestrippt und nach mehreren Waschzyklen mit einem Pan-STAT1-Antikörper erneut exponiert 
(Abb. 6). In diesen Versuchsreihen konnte keine Unterschiede im Tyrosin-Phosphorylierungsverhalten der vier STAT1-Varianten festgestellt werden (Abb. 7).

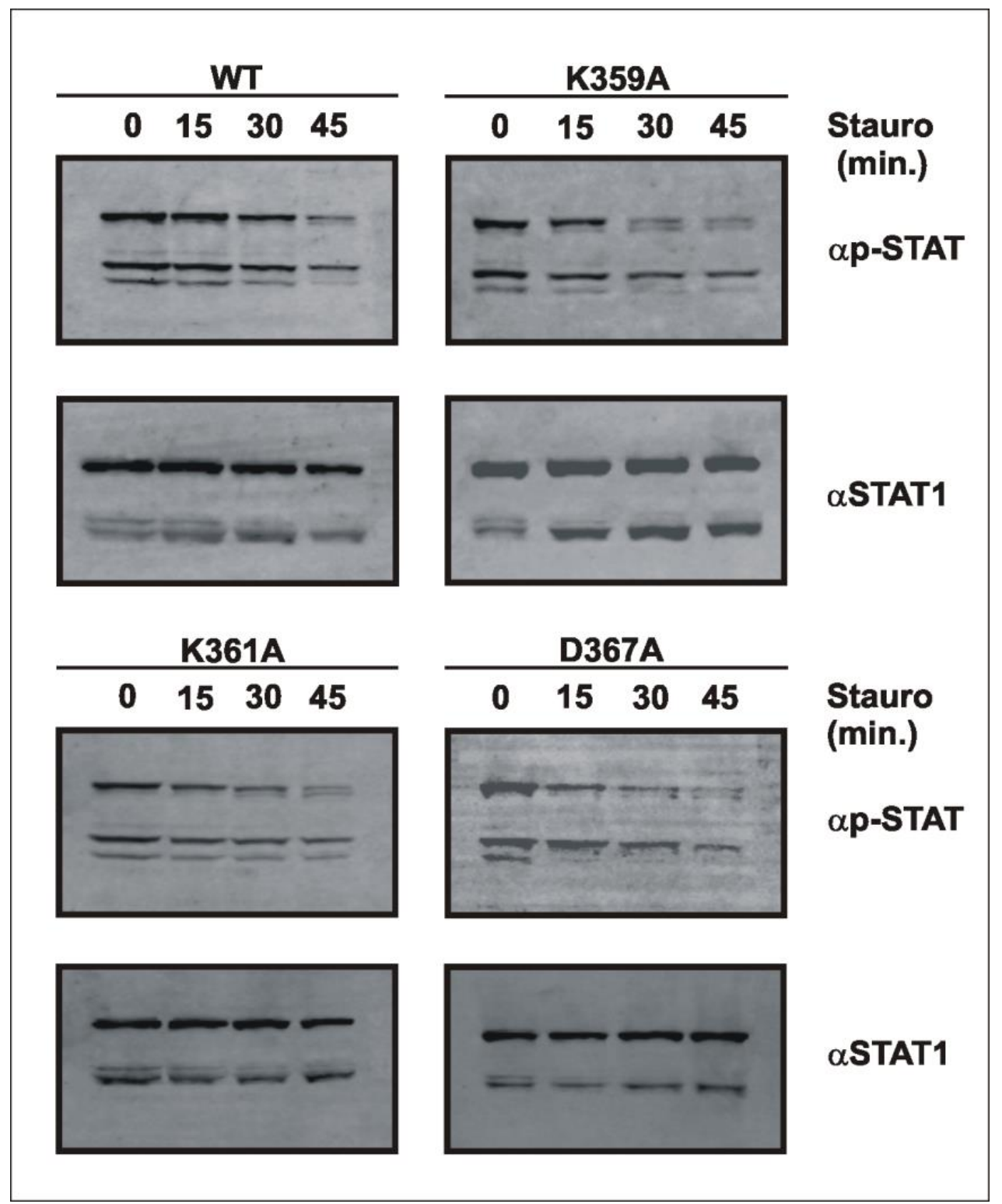

Abb. 6: Vergleichbare In-vivo-Phosphorylierungskinetik der drei Punktmutanten gegenüber STAT1-WT. Nach der Transfektion von HeLa-S3-Zellen mit pSTAT1-WT-, pSTAT-K359A, pSTAT-K361A- bzw. pSTAT-D367A-GFP und einer 45-minütigen Stimulation mit $10 \mathrm{ng} / \mathrm{ml}$ IFNY erfolgte eine Inkubation mit $1 \mu \mathrm{M}$ Staurosporin für unterschiedliche Zeitintervalle. Dargestellt sind die Ergebnisse repräsentativer Western-Blot-Analysen nach Inkubation mit einem Phospho-STAT1-Antikörper in den oberen Reihen sowie eine Reinkubation der Membranen mit einem STAT1-spezifischen Antikörper in den unteren Reihen. 


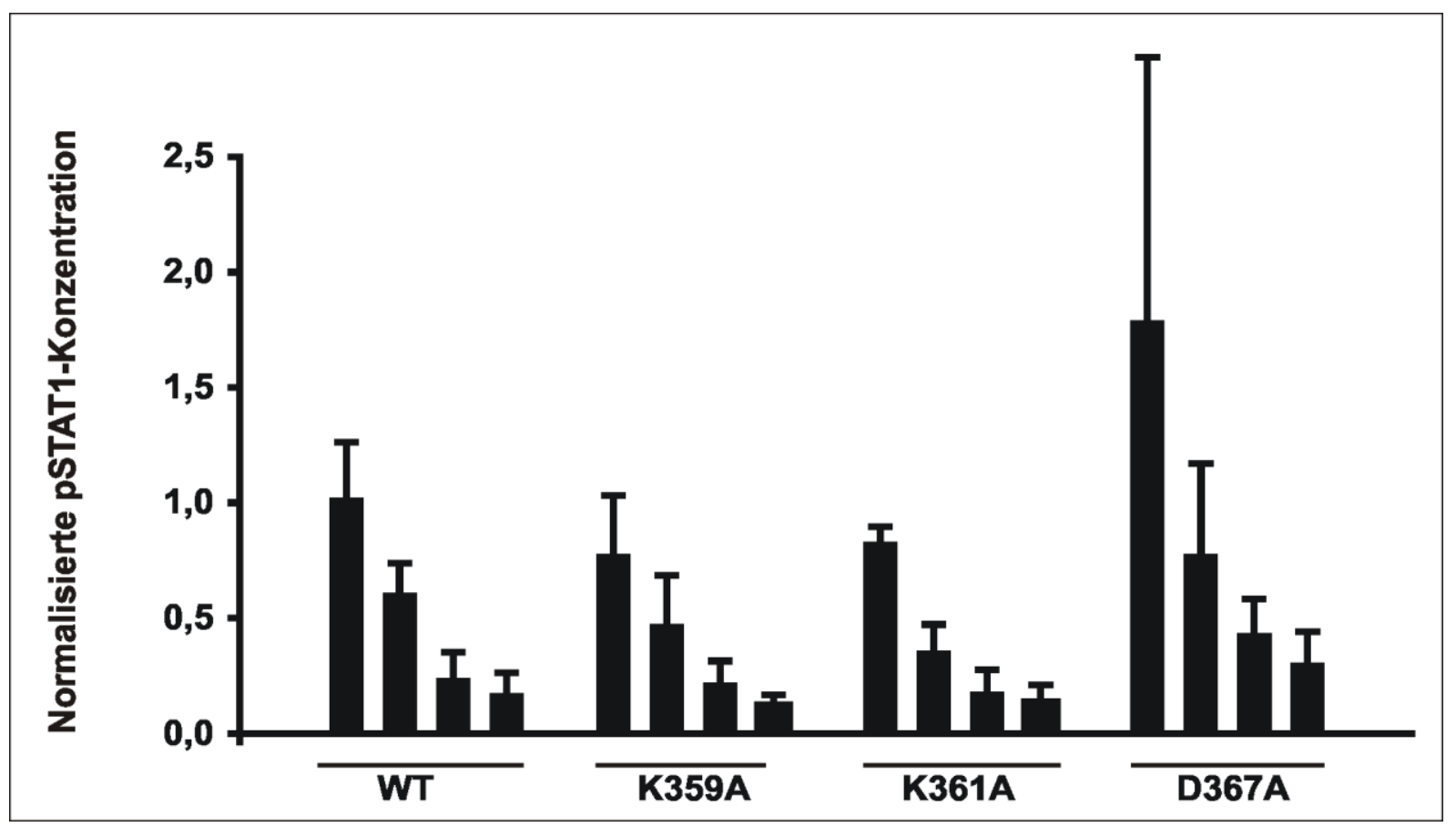

Abb. 7: Quantifizierung der Western-Blot-Versuche. Dargestellt ist die Abnahme der auf die STAT1-Expression bezogenen spezifischen Tyrosin-Phosphorylierung von IFNYvorbehandelten Zellen mit nachfolgend unterschiedlich langen StaurosporinBehandlungszeiten. Zur Berechnung der statistischen Signifikanz wurden die Ergebnisse aus mindestens zwei unterschiedlichen Versuchen quantifiziert

\subsection{Unauffällige Kinetik der IFNy-induzierten Kernakkumulation der drei Punktmutanten}

Durch die Verwendung von STAT1-GFP-Fusionsproteinen wurde die Kinetik der IFNY-induzierten Kernakkumulation fluoreszenzmikroskopisch eruiert. Im folgenden Experiment wurden sowohl die Dauer der Kernakkumulation nach erfolgter IFNYStimulation als auch dessen Zerfall nach Staurosporinbehandlung anhand der drei Mutanten mit dem STAT1-WT verglichen. Es erfolgte zunächst die Herstellung der einzelnen Mutanten mittels Mutagenese unter Verwendung von pEGFP-N1Plasmiden mit humaner STAT1 cDNA in 5 ${ }^{\circ}$-Position zur GFP-kodierenden Insertion. Zudem konnte im Weiteren die Art der Zellverteilung nach transienter Transfektion in HeLa-S3-Zellen dargestellt werden. Hierfür blieben die Zellen unstimuliert, für $45 \mathrm{~min}$ mit $10 \mathrm{ng} / \mathrm{ml}$ IFNy stimuliert oder zusätzlich zur IFNy-Stimulation mit $1 \mu \mathrm{M}$ Staurosporin inkubiert. Abschließend wurden die Zellen mit 3,7\% Formaldehyd/PBS fixiert und die Zellkerne mit Hoechst 33258 angefärbt. 
Die Abbildung 8 zeigt fluoreszenzmikroskopische Aufnahmen, die den unstimulierten Zustand von STAT1-WT und STAT1-K359A darstellen, wobei eindeutig eine panzelluläre Verteilung zu beobachten ist, die sich durch IFNY-Stimulation sowohl bei den WT-Proteinen als auch bei denen der Punktmutanten zugunsten einer nukleären Lokalisation umverteilt. Nach einstündiger Inkubation mit Staurosporin zur Inhibierung der Tyrosin-Kinaseaktivität, die eine weitere Phosphorylierung der STAT1-Moleküle unterbindet, wurde kein Unterschied zwischen den STAT1-Varianten im Zusammenbruch der Kernakkumulation festgestellt (Abb. 9). Die anfängliche nukleozytoplasmatische Ruheverteilung der STAT1-Proteine war nach dieser Zeit wiederhergestellt. 


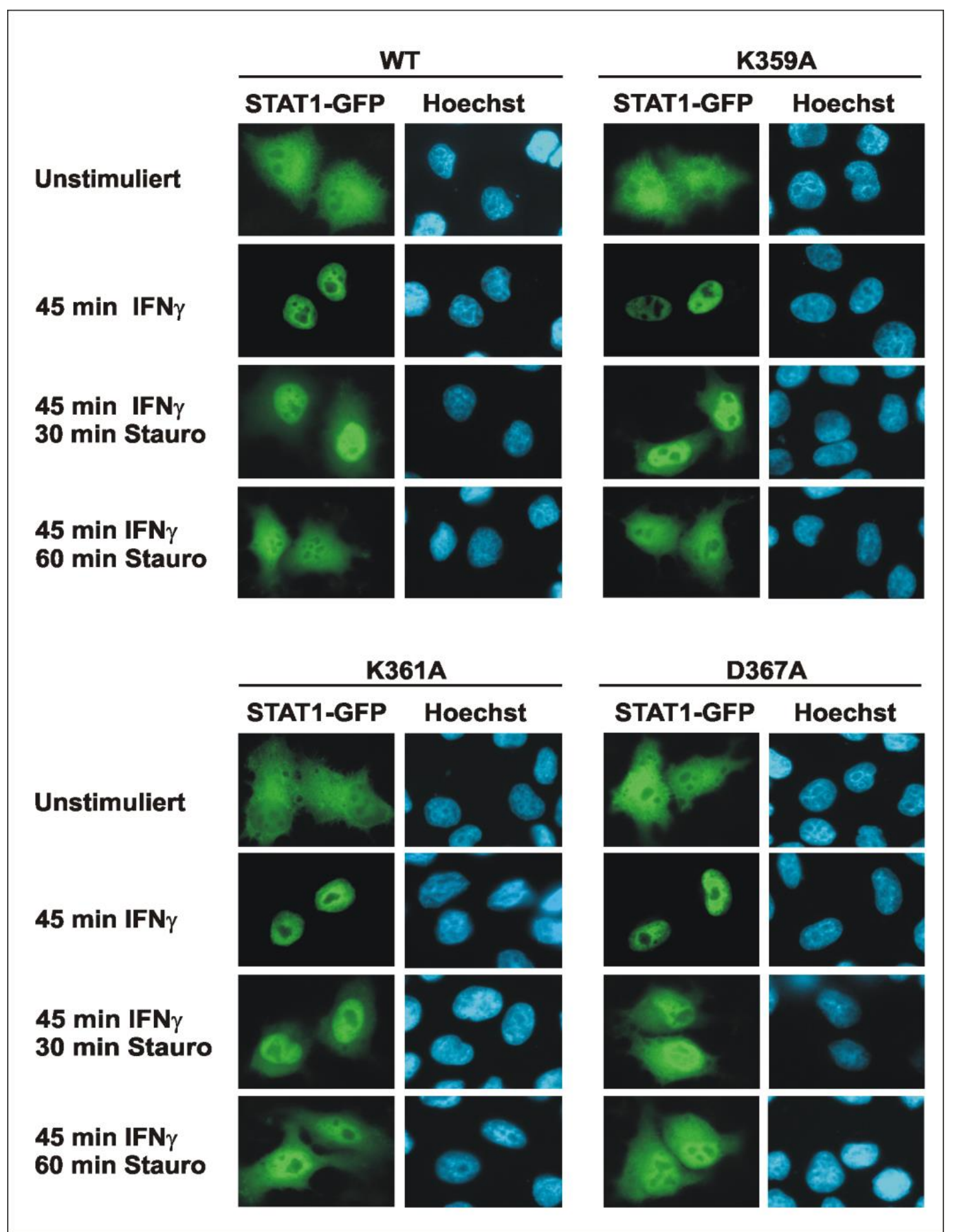

Abb. 8: Vergleichbare Kernlokalisation der drei Punktmutanten gegenüber STAT1-WT. HeLa-S3-Zellen wurden mit pSTAT1-WT-GFP, pSTAT1-K359A-GFP, pSTAT1-K361A-GFP oder pSTAT1-D367A-GFP transfiziert. Die Zellen wurden nach jeweiliger Stimulation mit 3,7\% Formaldehyd/PBS fixiert und deren Zellkerne mit Hoechst 33258 eingefärbt. Dargestellt sind der Reihe nach fluoreszenzmikroskopische Aufnahmen im unstimulierten Zustand, nach 45minütiger IFNY-Stimulation, nach 45-minütiger IFNY-Inkubation mit anschließender 30minütiger Staurosporin-Behandlung sowie nach 45-minütiger IFNY-Inkubation und anschlieBender 60-minütiger Staurosporin-Behandlung. 


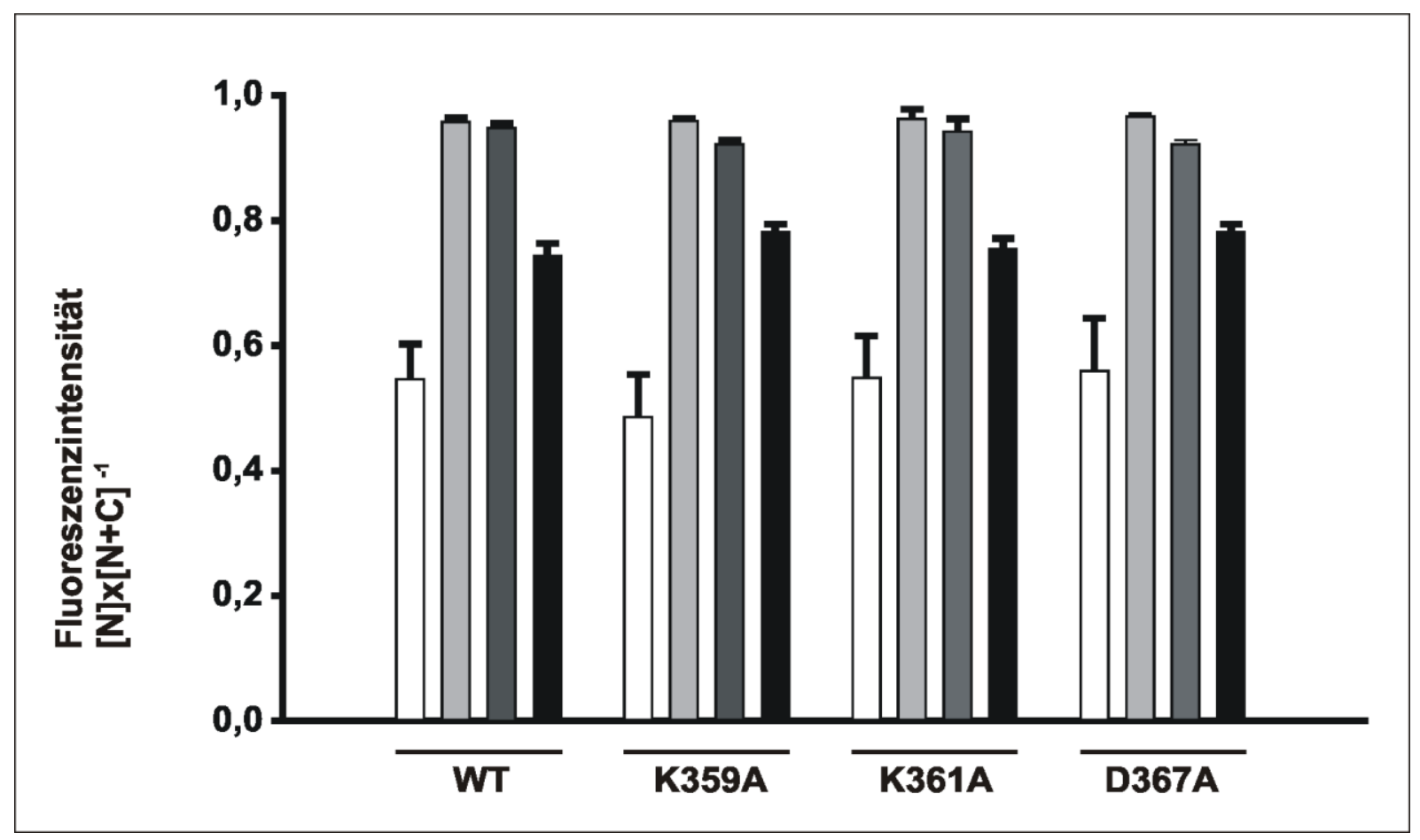

Abb. 9: Ähnliches IFNy-induziertes Akkumulationsverhalten dreier STAT1-Punktmutanten in der STAT1-DNA-Bindedomäne. In dieser Abbildung wird die Vergleichbarkeit durch eine Quantifizierung der einzelnen Bilder zusätzlich verdeutlicht. Die farbabgestuften Balken stehen für die unterschiedlichen Behandlungsabläufe der Zellen wie in Abb. 8 gezeigt, wobei unstimulierte Zellen mit weißen Säulen und IFNy-stimulierte und nachfolgend für 45 min mit Staurosporin behandelte Zellen als schwarze Säulen dargestellt sind. Ein vergleichbares Quantifizierungsverfahren wurde entsprechend dem folgenden Experiment mit pcDNA3.1STAT1-Plasmiden angewendet, das in der Abbildung 11 dargestellt ist.

Ein weiteres Experiment wurde mit pcDNA3.1-STAT1-Plasmiden durchgeführt. Es galt hierbei sicherzustellen, dass die subzelluläre Verteilung von STAT1 nicht durch ein Addition mit GFP beeinflusst wird, da von dem Fusionsprotein eine verringerte Exportrate beschrieben wurde (Köster und Hauser 1999; Begitt et al. 2000; Meyer et al. 2007). Es wurde gleichermaßen eine Transfektion, in diesem Fall von U3A-Zellen mit den entsprechenden pcDNA3.1-STAT1-Expressionsvektoren der jeweiligen STAT1-Moleküle durchgeführt. Es folgte eine Stimulation der Zellen mit IFNy und anschließender Inkubation mit Staurosporin. Durch die Immunfärbung mit STAT1spezifischen Antikörpern konnten die Präparate fluoreszenzmikroskopisch ausgewertet werden. Aus der Abbildung 10 geht hervor, dass nach 45-minütiger Stimulation mit IFNy eine Kernakkumulation beim STAT1-WT sowie allen drei Punktmutanten erfolgt. Die Behandlung mit einfachem Medium für 45 bzw. 90 min führte langsam wieder zu 
einer panzellulären Verteilung der STAT1-Moleküle, die nach anschließender 45minütiger Stimulation mit Staurosporin vollständig abgeschlossen war. Beide Experimente erbrachten keinen Hinweis darauf, dass die in dieser Arbeit verwendeten Punktmutanten von STAT1 in ihrer Kinetik der Kernakkumulation vom WildtypMolekül abwichen (Abb. 10 und 11). 


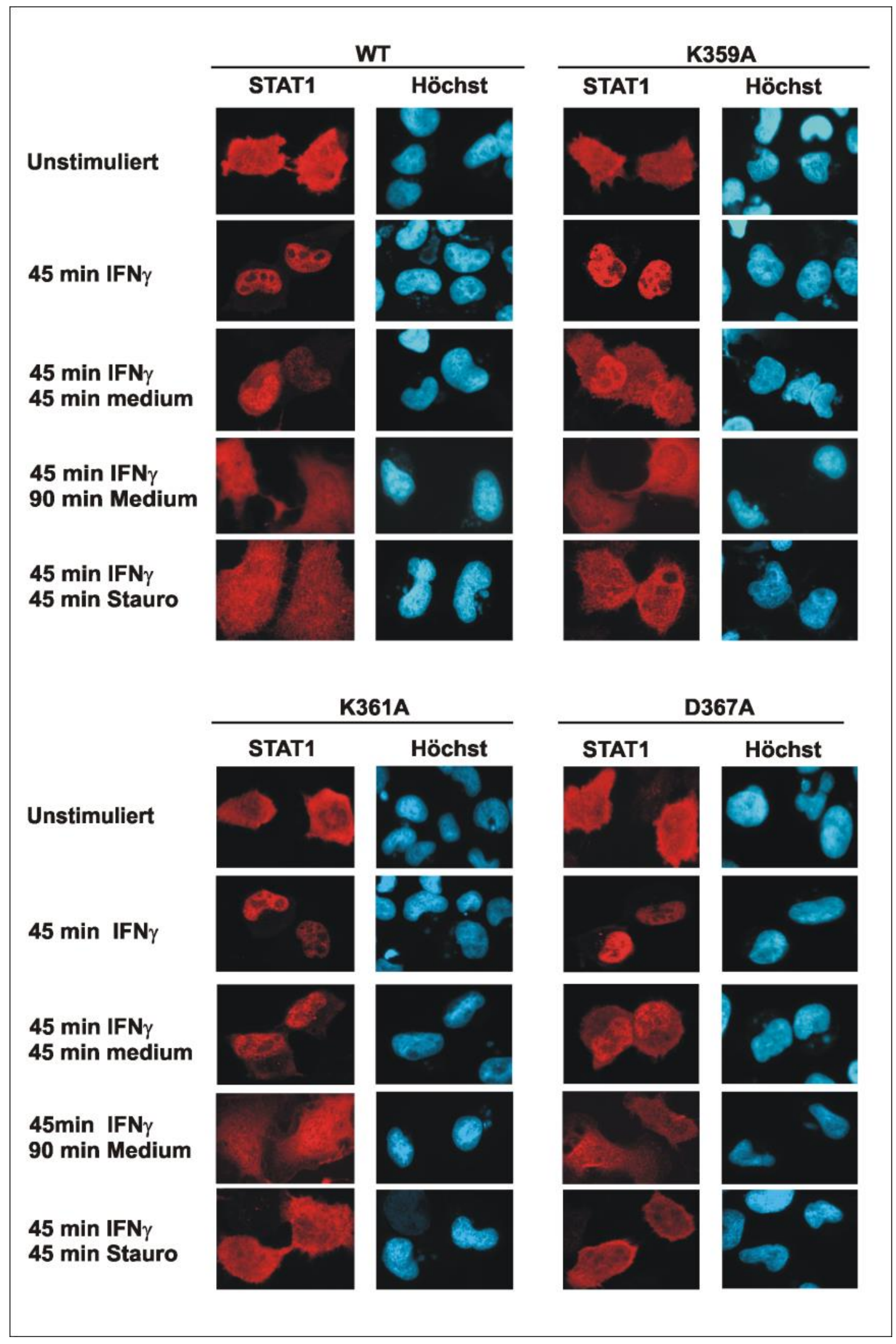

Abb. 10: Vergleichbare Kernakkumulation der drei Punktmutanten gegenüber dem STAT1-WT. U3A-Zellen, die entweder pSTAT1-WT, PSTAT1-K359A, PSTAT1-K361A oder pSTAT1-D367A exprimierten, wurden nach jeweiliger Stimulation mit Methanol fixiert. Die STAT1-Lokalisation wurde immunzytochemisch mit einem STAT1-spezifischen Antikörper und 
Cy3-gekoppeltem Anti-Kaninchen-IgG aus Ziege detektiert und anschließend die Zellkerne durch Hoechst-Farbstoff angefärbt. Dargestellt sind der Reihe nach fluoreszenzmikroskopische Aufnahmen im unstimulierten Zustand, nach 45-minütiger IFNY-Stimulation, nach 45minütiger IFNY-Inkubation mit anschließender 45-minütigen Medium-Behandlung, nach 45minütiger IFNY-Inkubation mit anschließender 90-minütiger Medium-Behandlung sowie nach 45-minütiger IFNy-Inkubation mit anschließender 45-minütiger Staurosporin-Behandlung.

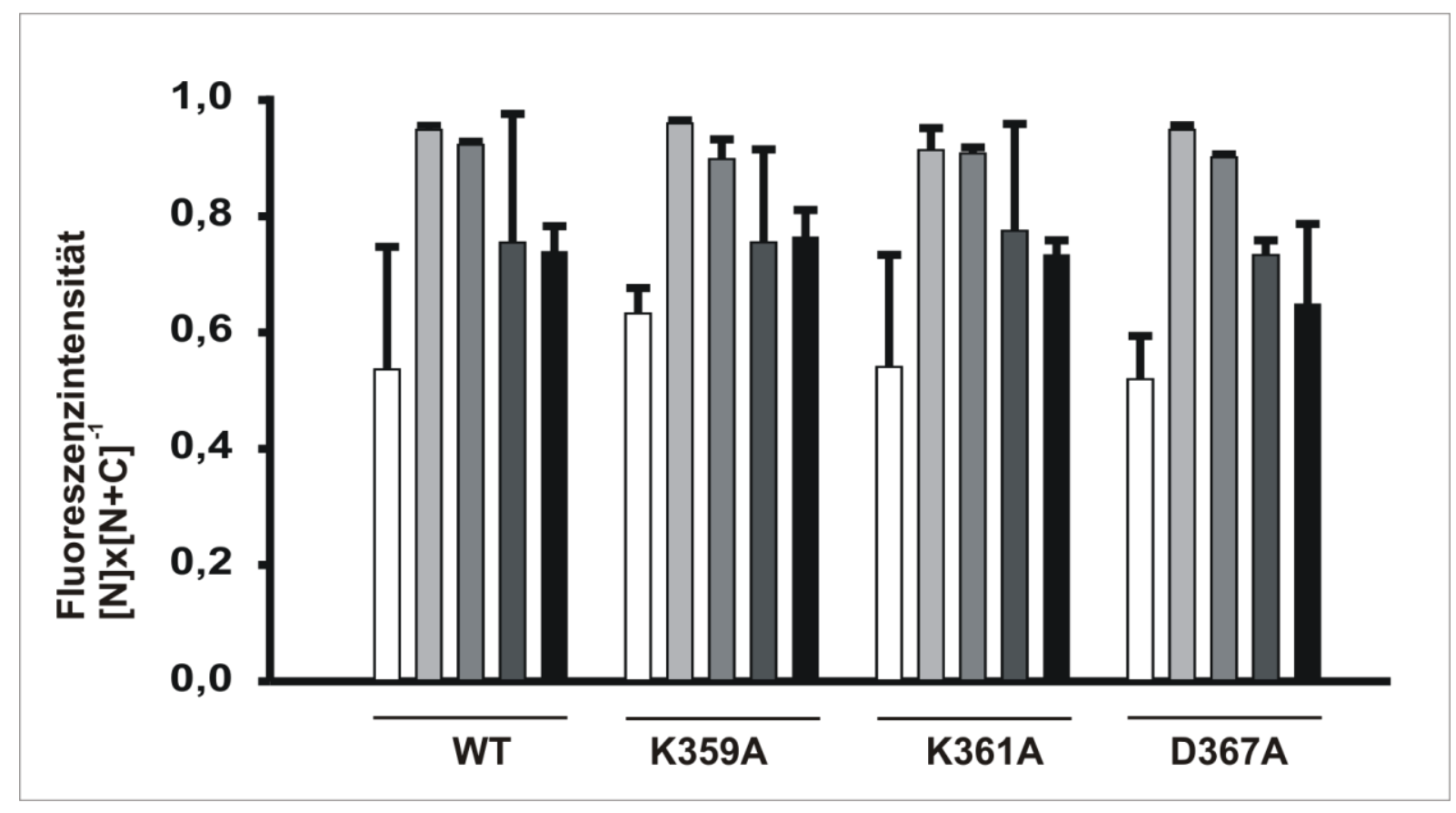

Abb. 11: Quantifizierung der nukleozytoplasmatischen Verteilung von rekombinanten STAT1-Mutanten in IFNy-stimulierten Zellen. Gezeigt ist der Quotient der nukleären zur gesamten Immunfluoreszenzintensität immunzytochemisch gefärbter Zellen, die die angegebenen STAT1-Varianten exprimierten. Die Zellen waren entweder im unstimulierten Zustand (weiße Säulen), 45 min mit IFNy stimuliert und sofort (hellgrau) oder 45 min später (mittelgrau) fixiert; andere Zellen wurden nach der IFNY-Stimulation für 45 min (dunkelgrau) oder 90 min (schwarz) mit Staurosporin behandelt.

\subsection{Die drei für diese Arbeit generierten Mutanten weisen eine normale Dis- soziationsrate von DNA auf}

Für die Durchführung von Kompetitions-Gelshift-Versuchen wurden wiederholt Gesamtzellextrakte aus IFNY-stimulierten, STAT1-WT-GFP-, -K359A-GFP-, -K361AGFP- und -D367A-GFP-exprimierenden U3A-Zellen hergestellt. Diese Extrakte wurden dann für 15 min mit einer $\left[{ }^{33} \mathrm{P}\right]$-markierten M67-Sonde versetzt und anschließend für die in der Abbildung 12 angegebenen Zeiten mit 750-fachem molaren Überschuss von unmarkierter M67-DNA inkubiert. Nach Ablauf der Inkubationszeit wurden die 
Zellextrakte mithilfe einer Polyacrylamid-Gelelektrophorese in nicht-denaturierenden Gelen aufgetrennt. In den Abbildungen 12 und 13 wird deutlich, dass im Hinblick auf die Dissoziationskinetik der GFP-markierten STAT1-Varianten keine Abweichungen in der Freisetzung von einer singulären GAS-Bindestelle entstehen.

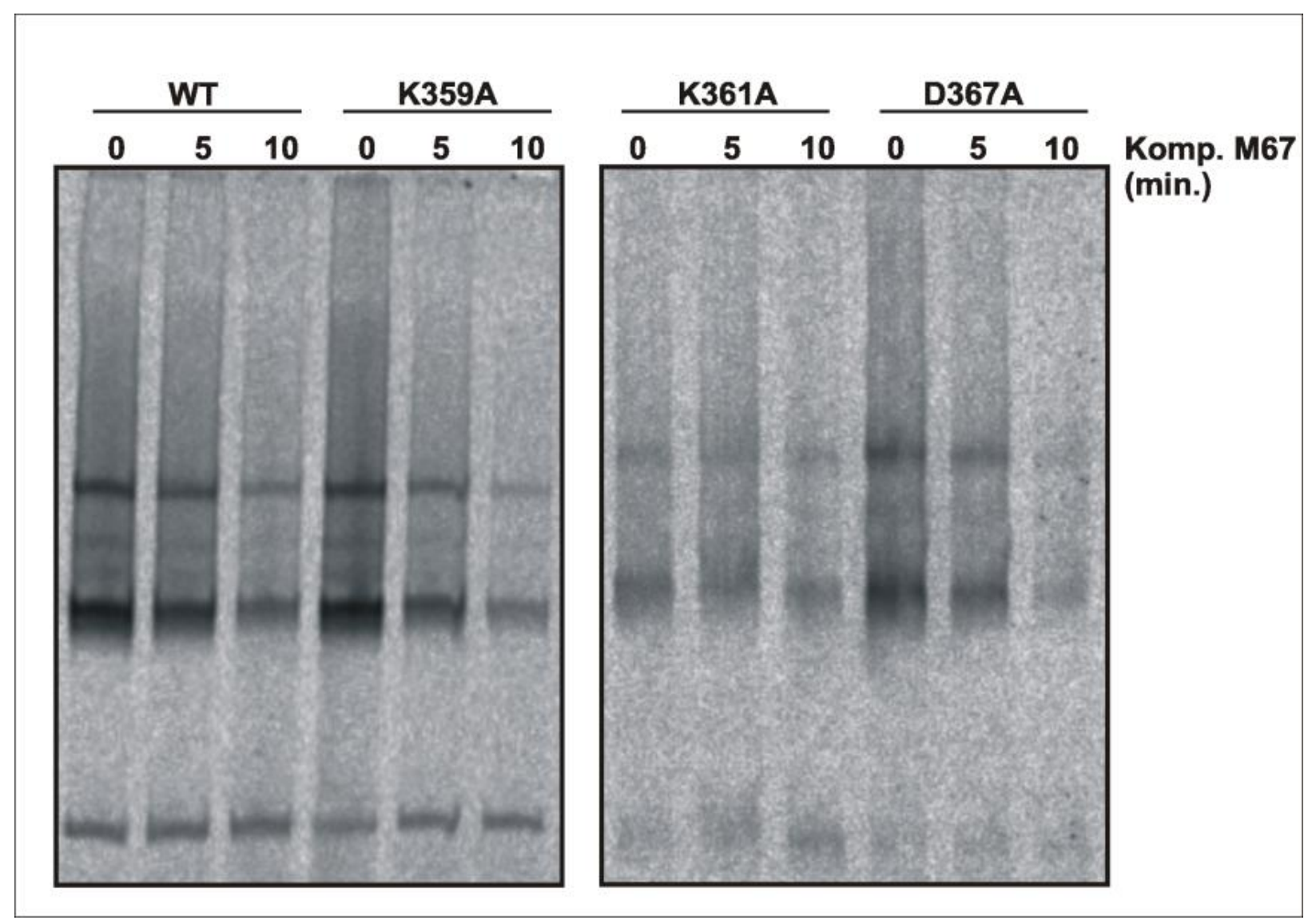

Abb. 12: Vergleichbare Dissoziationskinetik von STAT1-WT gegenüber den drei Punktmutanten. Dargestellt ist das Ergebnis eines repräsentativen Gelshift-Assays. Es wurden Hela-S3-Zellen mit pSTAT1-WT-GFP, pSTAT1-K359A-GFP, pSTAT1-K361A-GFP bzw. pSTAT1-D367A-GFP transfiziert, am Folgetag mit $10 \mathrm{ng} / \mathrm{ml}$ IFNy stimuliert und nukleäre Extrakte hergestellt, die anschließend für 15 min mit radioaktiv markierter M67-Sonde bestehend aus einer einfachen GAS-Bindestelle inkubiert wurden. Darauffolgend wurde eine unmarkierte M67-DNA im 750-fachen molaren Überschuss wie beschrieben für unterschiedliche Zeitintervalle zur Reaktion hinzugefügt, um direkt danach auf ein natives Polyacrylamid-Gel aufgetragen zu werden. Nach autoradiographischer Detektion sind die dimergebundenen STAT1-DNAKomplexe bestehend aus GFP-markiertem STAT1 (obere Banden) und endogenem STAT1 (untere Banden) zu unterscheiden. 


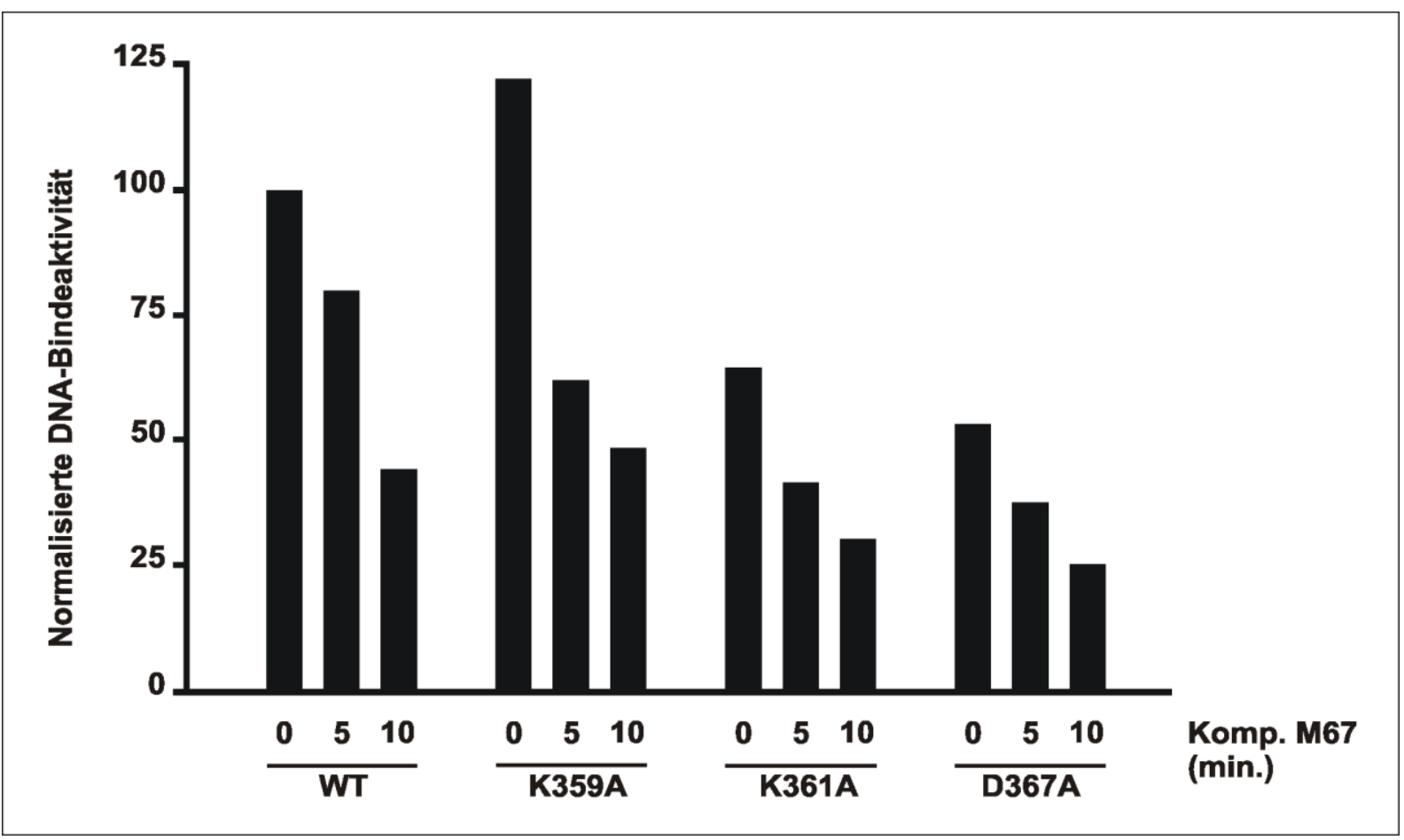

Abb. 13: Quantifizierung eines kompetitiven Gelshift-Assays zum Nachweis der Dissoziation von einer Konsensus-GAS-Bindestelle. Extrakte wurden entsprechend dem in Abb. 12 beschriebenen Protokoll behandelt. Die schwarzen Balken zeigen eine normalisierte DNA-Bindeaktivität nach Kompetition mit unmarkierter M67-DNA für unterschiedliche Zeitintervalle. Die Dissoziationskinetik des Wildtyps im Vergleich zu den drei Punktmutanten ist, wie in Abbildung 12 beschrieben, vergleichbar.

\subsection{STAT1-K359A, -K361A und -D367A zeigen eine normale kooperative DNA-Bindung}

Mit einem weiteren EMSA-Experiment wurde die Fähigkeit zur kooperativen DNABindung von den drei Punktmutanten untersucht. Es wurde eine $\left[{ }^{33} \mathrm{P}\right]$-markierte DNASonde mit einer zweifachen GAS-Bindestelle verwendet, um die Möglichkeit der Tetramerbildung zu überprüfen. Dieses ließ sich durch eine Kompetition mit 750-fachem Überschuss der unmarkierten M67-Sonde realisieren. Eine Zugabe dieser DNA gestattete die Untersuchung der Ablösung nicht-stabilisierter STAT1-Dimere von GASBindestellen in Tandem-Orientierung. U3A-Zellen, die mit PSTAT1-WT-GFP bzw. den entsprechenden für die Punktmutanten kodierenden Plasmiden transfiziert wurden, erhielten eine Behandlung für 45 min mit $10 \mathrm{ng} / \mathrm{ml}$ IFNy. Es wurden nukleäre Extrakte hergestellt, die anschließend für 30 min mit einer markierten 2xGas Sonde inkubiert wurden. Jede zweite Kammer des vertikalen Elektrophoresesystem (Minigel-Twin, 
Biometra) wurde zusätzlich mit einer unmarkierten M67-Sonde in 750-fachem Überschuss versetzt. Mittels autoradiographischer Detektion konnten Tetramer- sowie Dimerbanden aufgrund ihres unterschiedlichen Laufverhaltens, das durch den Größenunterschied der Molekülkomplexe bedingt ist, im nicht denaturierten Polyacrylamidgel voneinander unterschieden werden.

Sowohl STAT1-WT wie auch die für diese Arbeit generierten Punktmutanten sind in der Lage, durch Bindung an einer GAS-Bindestelle ein Dimer, aber auch durch Bindung an einer doppelten GAS-Bindestelle ein Tetramer auszubilden, wobei es bei einer Kompetition mit der unmarkierten M67-DNA immer zur Auflösung des weniger stabilen Dimers kommt (Abb. 14 und 15). Es liegt demnach bei keiner der Mutanten ein Tetramerisierungsdefekt vor. 


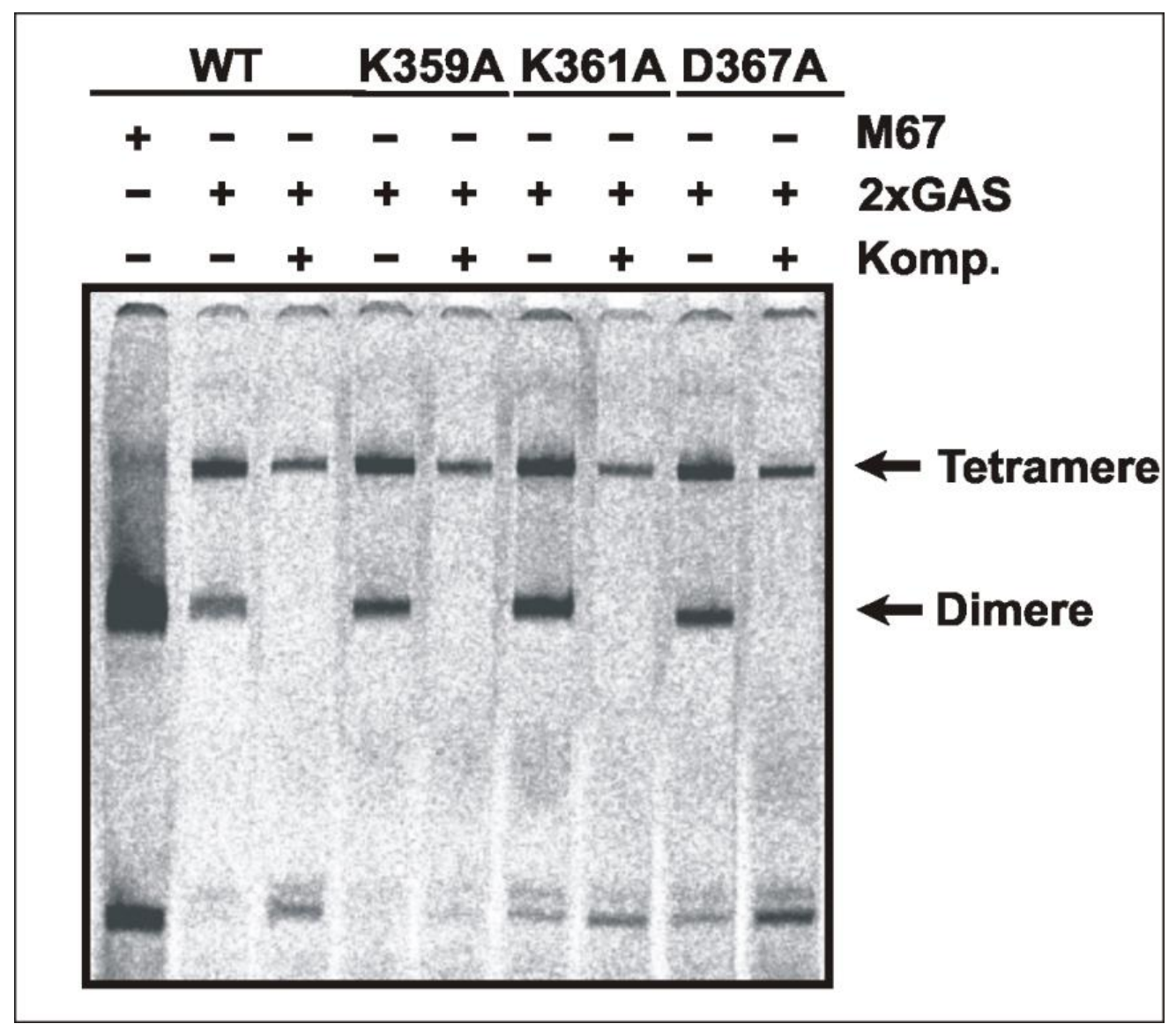

Abb. 14: Kein Hinweis auf Tetramerisierungsdefekte der Punktmutanten in der DNABindedomäne. Dargestellt ist das Ergebnis eines repräsentativen Gelshift-Assays zur Untersuchung der kooperativen DNA-Bindung. Es wurden U3A-Zellen mit pSTAT1-WT-GFP, -K359A-GFP, -K361A-GFP bzw. -D367A-GFP transfiziert und am Folgetag mit $10 \mathrm{ng} / \mathrm{ml}$ IFNy stimuliert und anschließend nukleäre Extrakte hergestellt. Diese wurden darauffolgend, wie im gezeigten Gelshift-Assay beschrieben, mit einer markierten 2xGAS-Sonde inkubiert, wobei jede zweite Kammer mit einem Inkubationsansatz beladen wurde, dem zuvor für 30 min unmarkierte M67-DNA in einem hohen molaren Überschuss zugegeben wurde. Nach autoradiographischer Detektion der gelelektrophoretisch aufgetrennten Proteine sind die tetramer- und die dimergebundenen STAT1-DNA-Komplexe deutlich zu unterscheiden. 


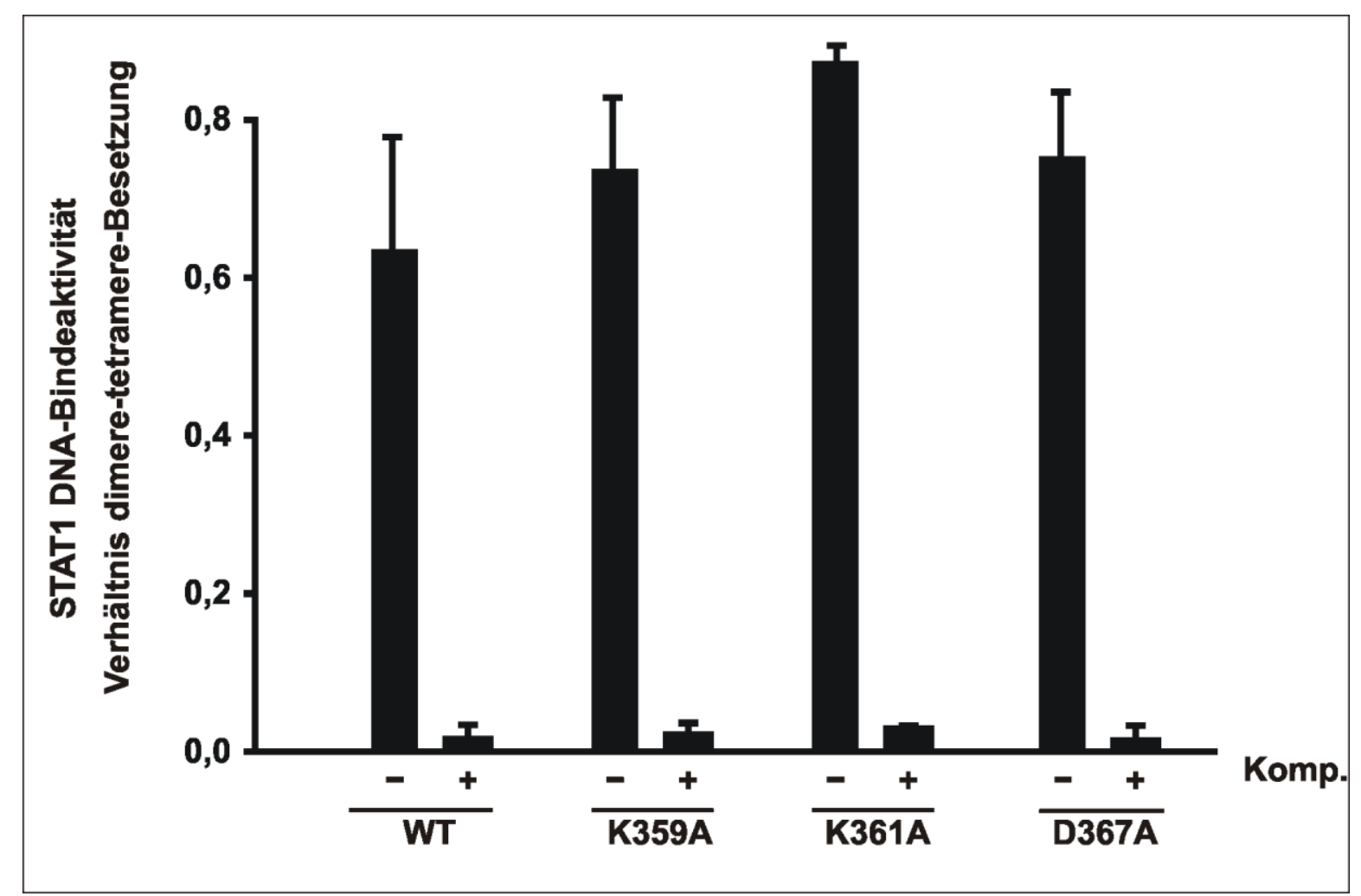

Abb. 15: Quantifizerung von Gelshiftassays zum Nachweis der intakten Tetramerstabilisierung der drei Punktmutanten. Die Quantifizierung von Gelshift-Assays, wie in Abbildung 14 gezeigt, verdeutlicht die erhaltene DNA-Bindeaktivität der STAT1-Varianten über die Bestimmung des Verhältnisses von dimerer zu tetramerer Besetzung. Die Kompetition ist beim Wildtyp wie auch bei den drei Punktmutanten vergleichbar und demonstriert die erhaltene kooperative DNA-Bindung.

\subsection{Alle Punktmutanten zeigen im Gelshift-Experiment eine regelrechte}

\section{DNA-Bindung}

Unter Verwendung des elektrophoretischen Mobilitäts-Shift-Assays (EMSA) konnten die spezifischen DNA-Bindungen vom STAT1-WT sowie den drei Punktmutanten STAT1-K359A, -K361A und -D367A untersucht werden. Hierzu erfolgte eine Transfektion von U3A-Zellen mit pSTAT1-WT-GFP bzw. pSTAT1-Mutante-GFP. Die Zellen wurden am darauffolgenden Tag für $45 \mathrm{~min}$ mit $10 \mathrm{ng} / \mathrm{ml} \mathrm{IFNy} \mathrm{stimuliert} \mathrm{und} \mathrm{für} \mathrm{die} \mathrm{in}$ der Abbildung 14 angegebene Zeit mit $1 \mu \mathrm{M}$ Staurosporin behandelt. Anschließend erfolgte die Herstellung von nukleären Zellextrakten, die dann für 15 min mit radioaktiv markierter M67-Sonde inkubiert wurden, welche über eine einfache GASBindestelle verfügt. Die Extraktmengen wurden gleichermaßen aufgetragen. Im Autoradiogramm konnte dann das Ausmaß der Bindung von phosphorylierten STAT1- 
Proteinen an die $\left[{ }^{33} \mathrm{P}\right]$-markierte Sonde dargestellt werden. Zudem war es möglich, durch die Verwendung von Anti-STAT1 $\alpha$-Antikörper ( $\alpha$ S1) und Anti-STAT3-Antiköper (aS3) als Kontrolle im Verlauf einer Supershift-Reaktion zu beweisen, dass es sich bei den detektierten Banden um STAT1-DNA-Komplexe handelt. Unter der Zugabe von aS1-Antikörpern, die gegen den STAT1-DNA-Komplex gerichtet waren, kam es aufgrund der Größenzunahme des Moleküls zu einer zusätzlichen Reduktion der Laufgeschwindigkeit, was zur Verschiebung bzw. zum teilweisen Verschwinden der STAT1-DNA-Bande im Gel führte. Als Negativkontrolle wurde eine Inkubation mit einem unspezifischen aS3-Antikörper als Zugabe zu den Zellextrakten vorgenommen, die im Gegensatz zum positiven Supershift bei vergleichbarer Extraktmenge keinerlei Veränderung im Laufverhalten der Komplexe aufwies.

Die Abbildung 16 zeigt einen ähnlich konstanten Bandenabfall in den mit Staurosporin behandelten Zellextrakten, sowohl beim STAT1-WT als auch bei den drei Mutanten. Dieses Ergebnis wird durch die Quantifizierung bestätigt: Ebenso wie im Western Blot als regelrechte Tyrosin-Phosohorylierung zeigt sich hier kein Hinweis auf ein abnormales Verhalten der Mutanten hinsichtlich der IFNY-induzierten DNA-Bindeaktivität (Abb. 17). 


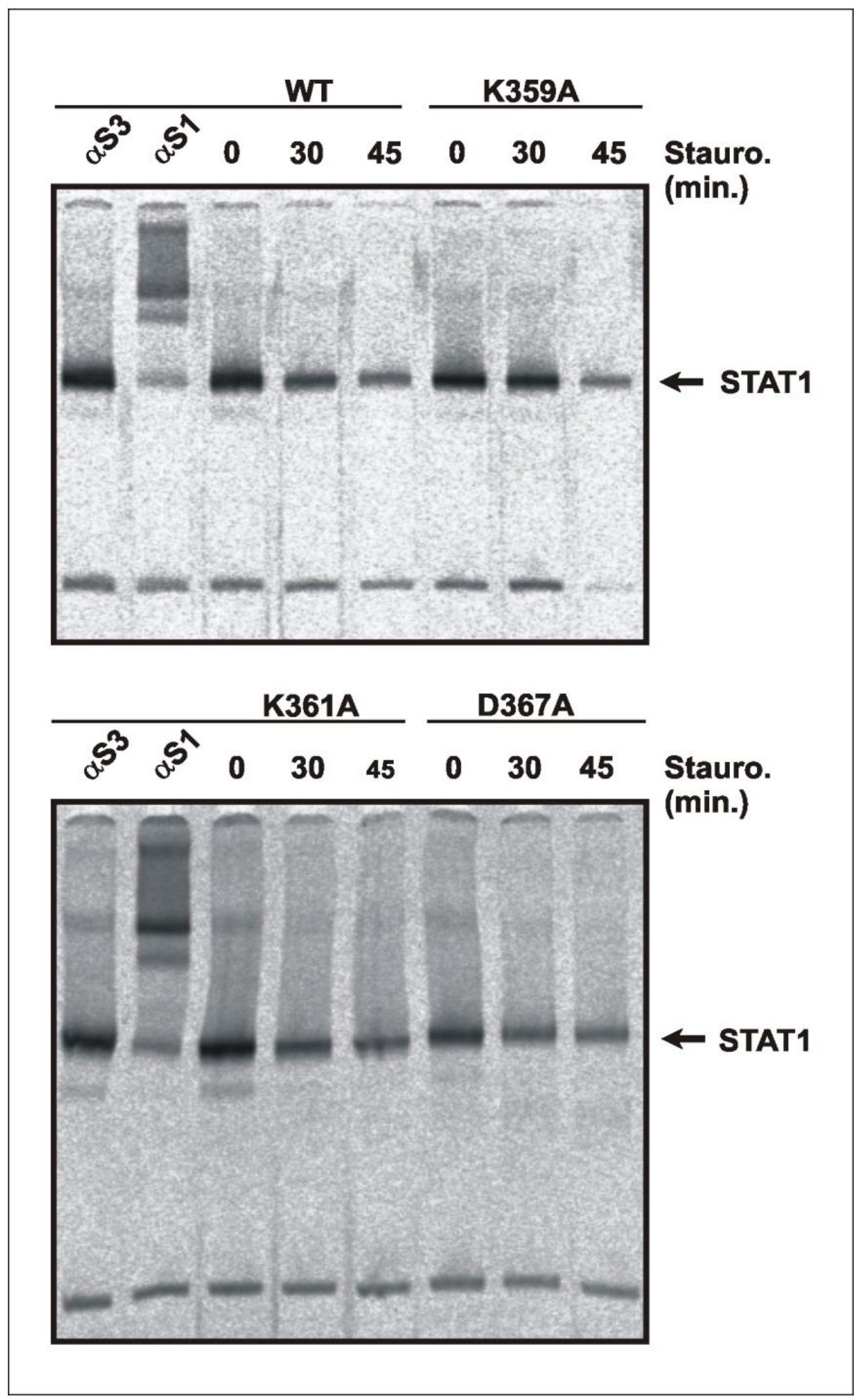

Abb. 16: Vergleichbare Bindung an M67-DNA von STAT1-WT und seinen drei hier untersuchten Punktmutanten. Dargestellt ist das Ergebnis eines repräsentativen Gelshift-Assays. Es wurden U3A-Zellen mit pSTAT1-WT-GFP, -K359A-GFP, -K361A-GFP bzw. -D367A-GFP transfiziert und anschließend mit $10 \mathrm{ng} / \mathrm{ml}$ IFNy sowie mit $1 \mu \mathrm{M}$ Staurosporin in steigenden 
Zeitintervallen stimuliert und daraus nukleäre Extrakte hergestellt, die einer 15-minütigen Inkubation mit einer $\left[{ }^{33} \mathrm{P}\right]$-markierten M67-Sonde unterzogen wurden. Darauf folgte eine gelelektrophoretische Auftrennung der Reaktionen, die Trocknung des Gels im Vakuum und final eine autoradiographische Detektion. Die Supershift-Reaktion wurde mit einem Anti-STAT1 $\alpha$-Antikörper ( $\alpha$ S1) sowie einem Anti-STAT3-Antiköper ( $\alpha$ S3) durchgeführt. Die zwei dargestellten Gele zeigen das Ergebnis nach Inkubation mit markierter M67-Sonde. Die durch einen Pfeil markierten Banden stellen detektierte STAT1-DNA-Komplexe dar.

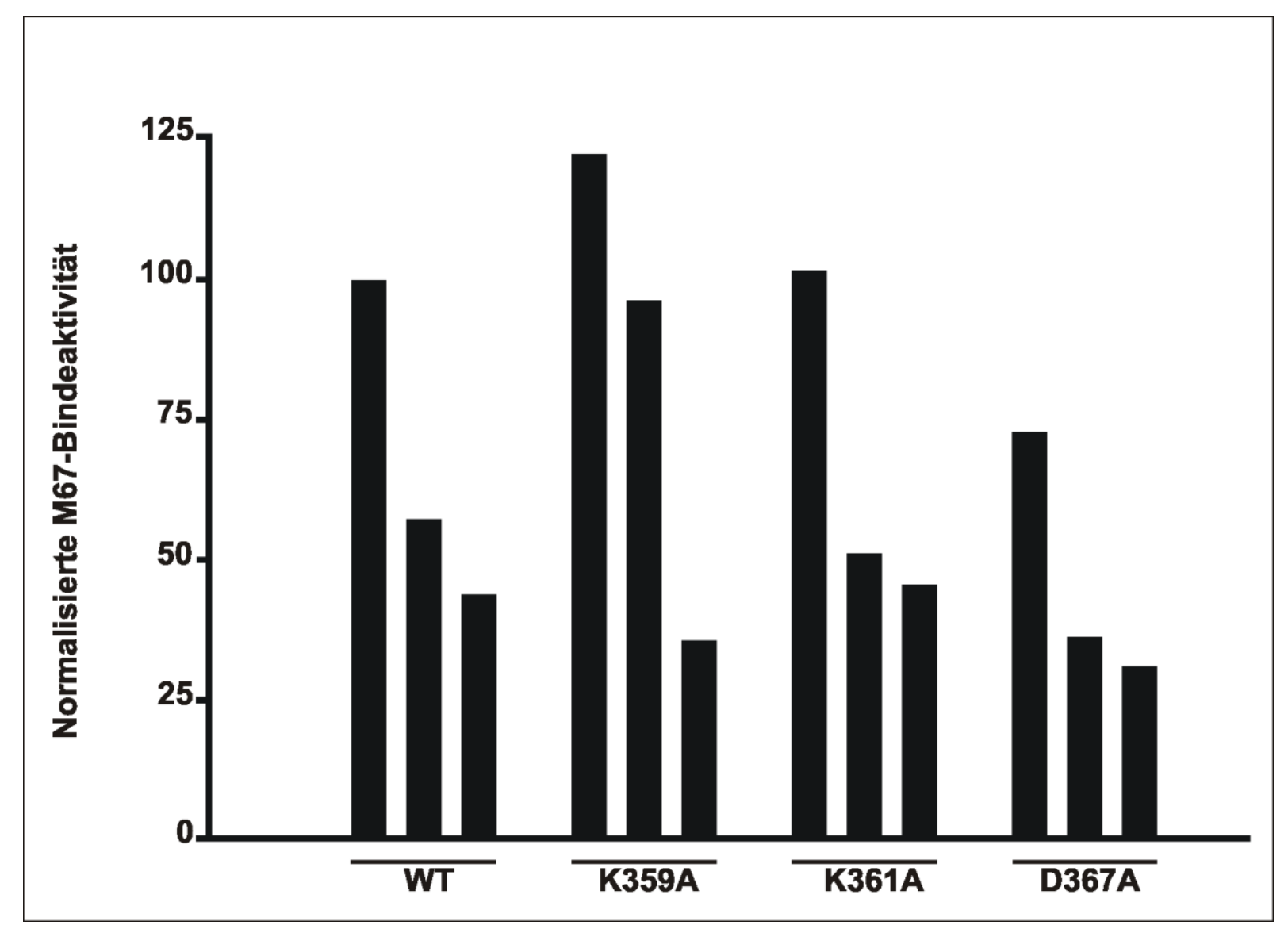

Abb. 17: Quantifizierung des Gelshift-Assays von Abb. 16. Die Abbildung zeigt eine vergleichbare M67-Bindeaktivität zwischen dem STAT1-WT und seinen drei Mutanten in der DNABindedomäne. Die hier bei der Mutante K359A beobachtete Bindeaktivität ließ sich in weiteren Experimenten nicht bestätigen.

\subsection{Die Mutanten dieser Arbeit haben eine mit dem STAT1-WT vergleichbare} Affinität zur DNA

Zur genauen Affinitätsanalyse der DNA-Bindung der drei Punktmutanten wurden unterschiedliche Gelshift-Experimente durchgeführt. Hierzu wurden nach 45-minü-tiger IFNY-Stimulation zelluläre Extrakte aus STAT1-WT-GFP-, -K359A-GFP-, -K361A-GFP- und -D367A-GFP-exprimierenden U3A-Zellen hergestellt und an- 
schließend mit radioaktiv markierten DNA-Sonden inkubiert. Als DNA-Proben wurden unterschiedliche Sonden eingesetzt. Die erste Sonde enthielt eine doppelte GAS-Bindestelle (2xGAS), die zweite Sonde eine einfache, sowie eine degenerierte GAS-Bindestelle (GASnonGAS) und die dritte Sonde war mit einer zweifachen NichtGAS-Sonde (2xnonGAS) bestückt. Es konnte unter Verwendung aller Sonden kein signifikanter Unterschied in der DNA-Bindeaffinität zwischen den Punktmutanten und dem STAT1-WT festgestellt werden (Abb. 18).

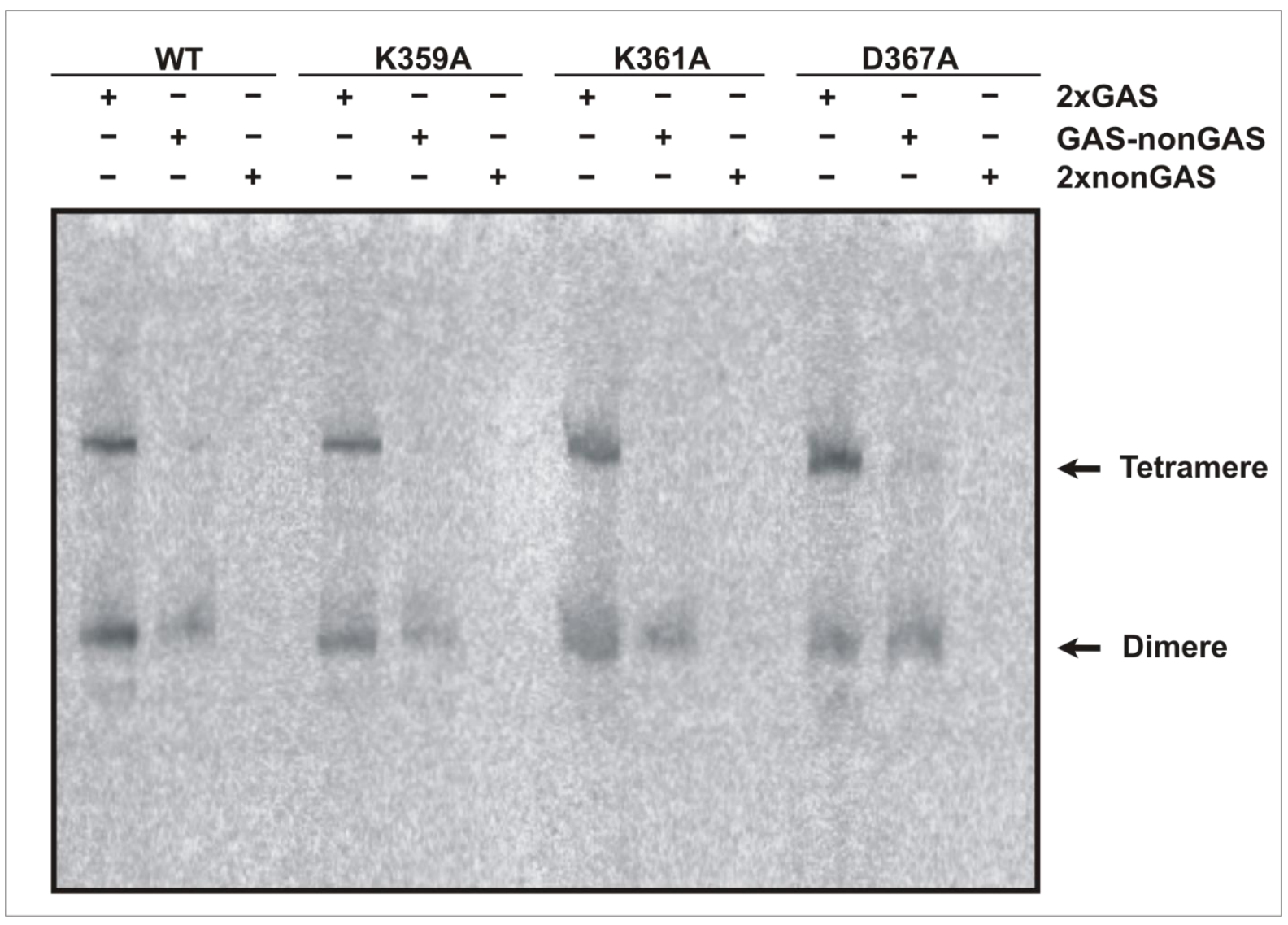

Abb. 18: Vergleichbare Affinität der DNA-Bindung vom STAT1-WT gegenüber den drei Punktmutanten. Dargestellt ist das Ergebnis eines repräsentativen Gelshift-Assays. Es wurden U3A-Zellen mit pSTAT1-WT-GFP, -K359A-GFP, -K361A-GFP bzw. -D367A-GFP transfiziert und für $45 \mathrm{~min}$ mit $10 \mathrm{ng} / \mathrm{ml}$ IFNy stimuliert und nukleäre Extrakte hergestellt. Diese wurden darauffolgend, wie im gezeigten Gelshift-Assay beschrieben, mit verschiedenen $\left[{ }^{33} \mathrm{P}\right]$-markierten Sonden inkubiert. In vakuumgetrockneten Gelen fand nach der Polyacrylamid-Gelelektrophorese die autoradiographische Auswertung der gelelektrophoretisch aufgetrennten Proteine statt. Die tetramergebundenen STAT1-DNA-Komplexe und die dimeren Komplexe sind zu unterscheiden und durch Pfeile markiert. 


\subsection{Es besteht eine vergleichbare Reportergen-Aktivität zwischen dem}

\section{STAT1-WT sowie den Mutanten}

Um feststellen zu können, ob sich die durchgeführte Mutation auf die Genaktivierung auswirkt, wurde ein Reportergen-Assay durchgeführt. Es erfolgte eine Transfektion von U3A-Zellen mit pSTAT1-WT-GFP bzw. K359A-GFP, -K361A-GFP oder -D367AGFP und pGAS3xLy6E sowie $p \beta G$ al. Das Luciferase-Reportergenkonstrukt ist ein synthetischer Promotor, der drei GAS-Bindestellen enthält, die hintereinander in einem Abstand von 10 bp aufgereiht sind (3xLy6E). Die verwendeten Zellen wurden am Folgetag der Transfektion unstimuliert belassen bzw. mit $5 \mathrm{ng} / \mathrm{ml} \mathrm{IFNy}$ für $6 \mathrm{~h}$ stimuliert. Es folgten eine spektrometrische Messung der Luciferase-Aktivität im Photometer und eine Normierung der gemessenen Aktivität auf die $\beta$-Galactosidaseaktivität. Abbildung 19 zeigt eine vergleichbar hohe transkriptionelle Aktivität zwischen den einzelnen Mutanten und dem STAT1-WT. Dieses Experiment deutet darauf hin, dass durch die Einführung der Punktmutationen an den Positionen 359, 361 und 367 die transkriptionelle Aktivität der mutierten STAT1-Proteine gegenüber der von STAT1-WT nicht signifikant abweicht.

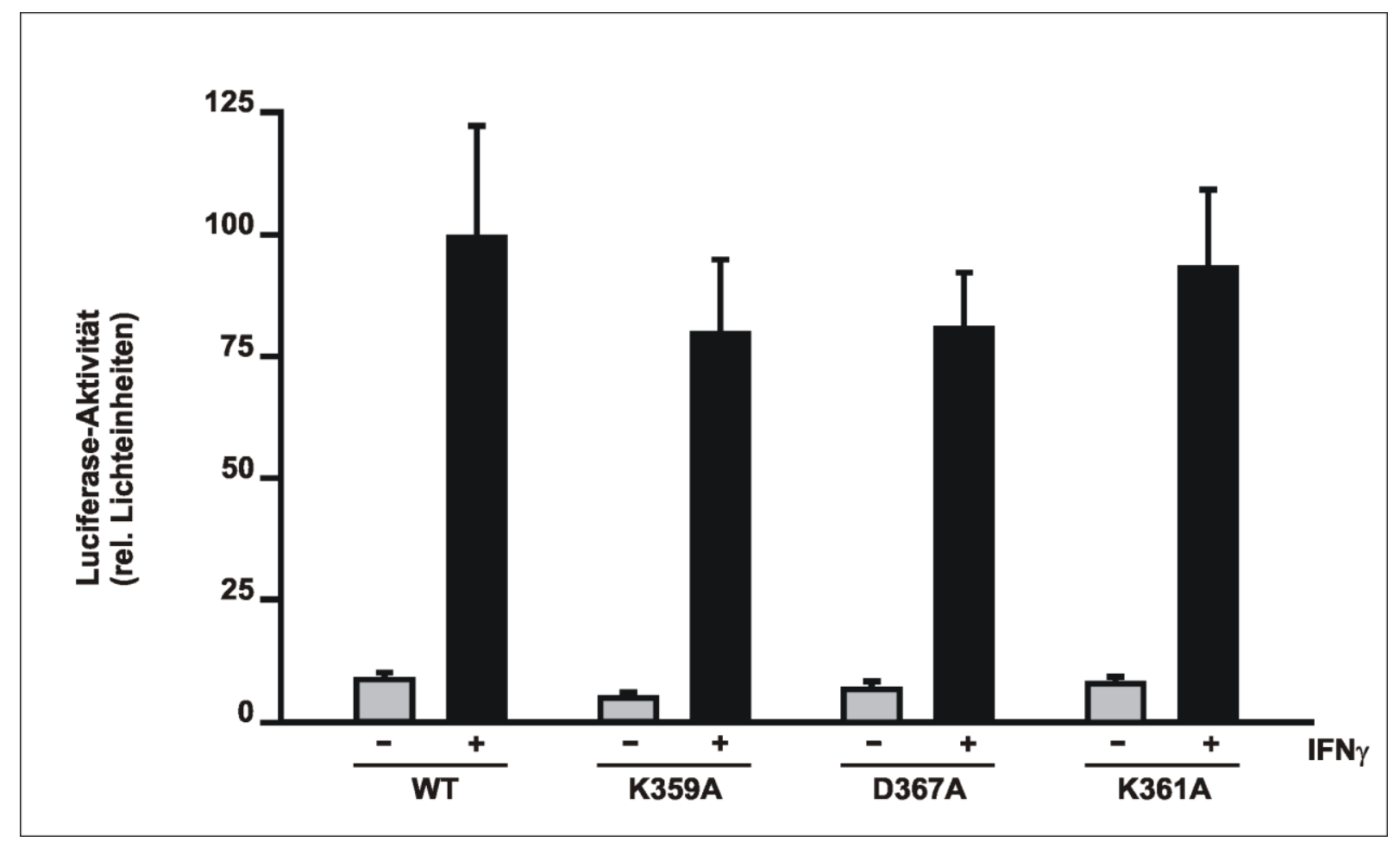

Abb. 19: Vergleichbare transkriptionelle Aktivität vom STAT1-WT gegenüber den drei Punktmutanten. Nach der Transfektion von U3A-Zellen mit den Vektoren pSTAT1-WT -K359A,-K361A bzw. -D367A und den Reportergen-Konstrukten p3xLy6E und pBGal blieben 
die Zellen entweder unbehandelt (graue Balken) oder es fand 16-24 h später eine Stimulation mit $5 \mathrm{ng} / \mathrm{ml}$ IFNy für $6 \mathrm{~h}$ statt (schwarze Balken). Durch die Gewinnung von Zellextrakten konnte die Luciferase-Aktivität in Proben vergleichbarer Zellzahl gemessen werden. Die Normierung der Luciferase-Aktivität erfolgte auf die spektrometrisch gemessene $\beta$-GalactosidaseAktivität der korrespondierenden Probe.

\subsection{Die generierten Punktmutanten weisen in der Expression bekannter STAT1-Zielgene keine signifikanten Unterschiede zum STAT1-WT auf}

Mit der real-time PCR konnte die Induktion von nativen STAT1-Zielgenen In-vivo erfasst werden. Die Untersuchung der Genexpression fand mithilfe einer Doppelbestimmung an literaturbekannten endogenen STAT1-Zielgenen statt, deren Aktivierung durch IFNY-Stimulation induziert wird. Über eine Messung von emittierten Fluoreszenzsignalen konnte eine direkte Abschätzung über die entstehende Menge der Target-DNA getroffen werden. Dies war möglich, da die Fluoreszenzzunahme das Ausmaß der Genexpression widerspiegelt. Um eine Quantifizierung der erhobenen Expressionsdaten durchführen zu können, erfolgte eine Normierung aller Daten der jeweiligen STAT1-Zielgene auf die Genexpression des Haushaltsgens gapdh. Für die Durchführung von real-time Experimenten wurden U3A-Zellen mit dem pcDNAKonstrukt pSTAT1-WT oder den entsprechenden Plasmiden, die für die Mutanten K359A, K361A bzw. D367A kodieren, transfiziert. Daraufhin folgte eine Kultivierung der Zellen in serumarmem Kulturmedium mit 1\% FBS und eine Stimulation am Folgetag für $6 \mathrm{~h}$ mit $10 \mathrm{ng} / \mathrm{ml}$ IFNy, wobei als Kontrolle die Zellen unstimuliert blieben. Anschließend konnte die RNA aus den STAT1-exprimierenden U3A-Zellen isoliert und schließlich in cDNA umgeschrieben werden, um hieraus die Genexpression mithilfe der RT-PCR quantitativ ermitteln zu können.

In der folgenden Abbildung sind das Wildtyp-STAT1-Molekül und die drei Punktmutanten in Bezug auf ihre Aktivierung endogener Zielgene vergleichend dargestellt (Abb. 20). Es wird deutlich, dass mit Berücksichtigung der Standardabweichungen bei gleicher Expression aller STAT1-Derivate keine signifikanten Unterschiede in der Genexpression drei bekannter STAT1-Zielgene irf1, mig1 und gbp1 zu verzeichnen sind. 


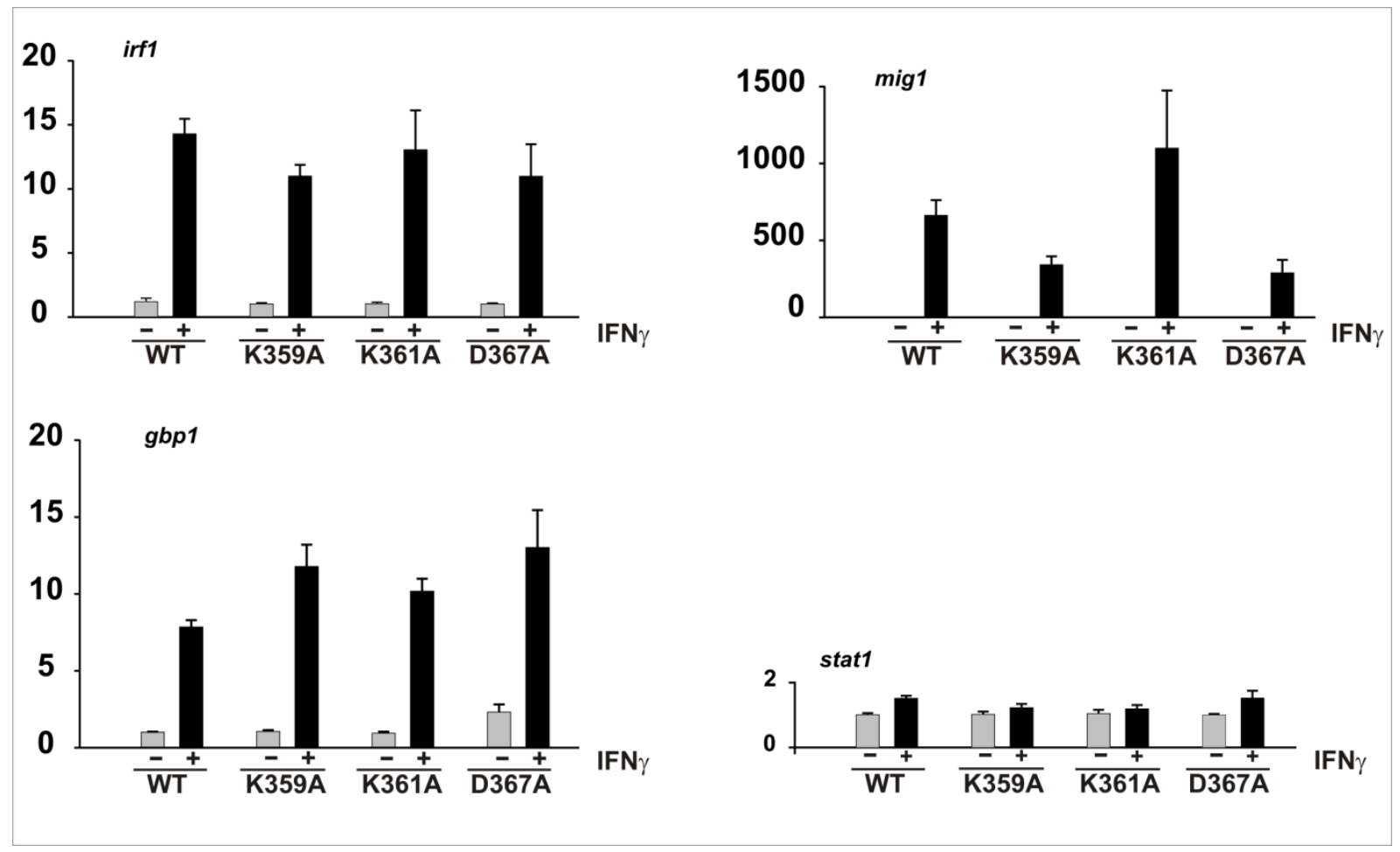

Abb. 20: Alle Punktmutanten zeigen eine ähnliche Genaktivierung.

Die mit PSTAT1-WT oder pSTAT1-Mutanten transfizierten U3A-Zellen wurden nach der Transfektion in Nährmedium mit 1\% FBS kultiviert. Am folgenden Tag wurden die Zellen für $6 \mathrm{~h}$ mit $10 \mathrm{ng} / \mathrm{ml}$ Interferon-y (siehe schwarze Balken) stimuliert oder, durch die grauen Balken dargestellt, unbehandelt gelassen. Aus den lysierten Zellen wurde die RNA extrahiert und cDNA hergestellt. Durch die real-time PCR konnte die Genexpression der STAT1-Zielgene erfasst und anschließend auf die Induktion des Haushaltsgenes gapdh normiert werden. Standardabweichungen sowie Mittelwerte wurden durch Doppelbestimmungen ermittelt. 


\section{Diskussion}

Vor mehr als zwei Jahrzehnten stellten Levy und DaRnell fest, dass eine Gentranskribierung innerhalb von Minuten eingeleitet werden kann, nachdem oberflächliche Zellrezeptoren durch Polypeptidliganden aktiviert worden waren (Levy und Darnell 1990). Der JAK-STAT-Weg stellt einen vergleichsweise gut untersuchten, direkten Signaltransduktionsweg zu polypeptidstimulierten Genaktivitäten dar (Ihle und Kerr 1995; Briscoe et al. 1996; Leaman et al. 1996; Darnell 1997). Er beinhaltet die Phosphorylierung von Signaltransduktoren und Aktivatoren der Transkription (STATProteine) durch rezeptorassoziierte Kinasen (Darnell et al. 1994; Schindler und Darnell 1995). Durch die Stimulation mit IFNy wird eine Signalweiterleitung ausgelöst. Dies geschieht durch die Ausbildung von STAT1/STAT1-Homodimeren bzW. von STAT1/STAT2-Heterodimeren nach Stimulation der Zellen mit IFNy bzW. IFN $\alpha$. Wird eine Janus-Kinase durch Änderung der Rezeptorkonfiguration aktiviert, phosphoryliert sie die STAT-Moleküle an ihrem kritischen Tyrosinrest und diese werden danach mithilfe von Transportmechanismen in den Zellkern transportiert. Im Kern kommt es zur DNA-Bindung und weiter zur Transkription von IFN-induzierten Genen. Ohne die Tyrosin-Phosphorylierung ist somit weder eine Akkumulation der Proteine im Nukleus noch ihre hochaffine Bindung an die DNA noch die zytokinabhängige Zielgenaktivierung möglich. Die Tyrosin-Phosphorylierung ist demnach die wichtigste Voraussetzung für diese Vorgänge. Alle in dieser Arbeit geschilderten Experimente sind darauf ausgelegt, die mutierten STAT1-Proteine in Hinblick auf diese Eigenschaften zu charakterisieren.

Der Schwerpunkt dieser Arbeit liegt auf der DNA-Bindedomäne. Die übliche Struktur der DNA-Bindedomäne ist die einer Immunoglobinfaltung (Bork et al. 1994). Die Beta-Stränge dieser Domäne laufen fast alle parallel zur ihrer Hauptachse, die senkrecht zur DNA-Strangrichtung orientiert ist. Daraus resultiert, dass alle Schlingen des einen Endes der Beta-Faltblattanordnung zur DNA hin ausgerichtet sind und die Aminosäuren, in 4 Segmente eingeteilt, Kontakt mit der DNA aufweisen. Das vierte Segment ist als ein bedeutendes Segment der DNA-Bindedomäne am tiefsten in die große Furche eingefügt. Zwischen der phosphatbindenden Schlaufe und dem vierten Segment der DNA-Bindedomäne besteht eine gekoppelte Wechselwirkung, welche die Chancen erhöht, dass die DNA-Bindung in den STATs ebenso direkt von der SH2-Domäne reguliert werden könnte. Dies geschieht in Ergänzung zum offensichtli- 
chen Effekt der SH2-Domäne auf die Dimerisation über die Linker-Domäne. Dieses Merkmal ist womöglich ein essentieller Bezug auf den durch Phosphatasen durchgeführten Abbau von DNA-gebundenen STAT-Komplexen (Chen et al. 1998). Bislang konnte der Einfluss einer verbesserten STAT1-Bindung an der DNA bei erhaltener GAS-Stellen-Erkennung im Hinblick auf die transkriptionelle Zielgenaktivierung nicht systemisch erforscht werden. Zur Aufklärung der STAT1-Signaltransduktion wären STAT1-Mutanten, die diese Eigenschaften besitzen, bezüglich der Kernlokalisation, der Promotorerkennung und der Genaktivierung von großer Nützlichkeit. In dieser Arbeit wurden folglich drei Aminosäurereste in der DNA-Bindedomäne mutiert, um mögliche Abweichungen, besonders im Hinblick auf die Bestimmung des DNABindeverhaltens und der Tyrosin-Dephosphorylierung, in unterschiedlichen Experimenten detektieren zu können. Durch die Punktmutation von zwei konservierten und daher möglicherweise strukturell wichtigen Lysinresten in den Positionen 359 und 361 sowie eines partiell konservierten Asparaginsäurerestes in Position 367 innerhalb der DNA-Bindedomäne wurde deren Einfluss auf die DNA-Bindung und somit auf die Amplitude der Signalweiterleitung getestet. Da entsprechend der vorliegenden Kristallstruktur des DNA-gebundenen STAT1 von keiner direkten Interaktion dieser Reste mit der DNA-Doppelhelix ausgegangen werden kann, sollte es sich hierbei um Effekte handeln, die den vermuteten Konformerenwechsel betreffen (Zhong et al. 2005; Mertens et al. 2006).

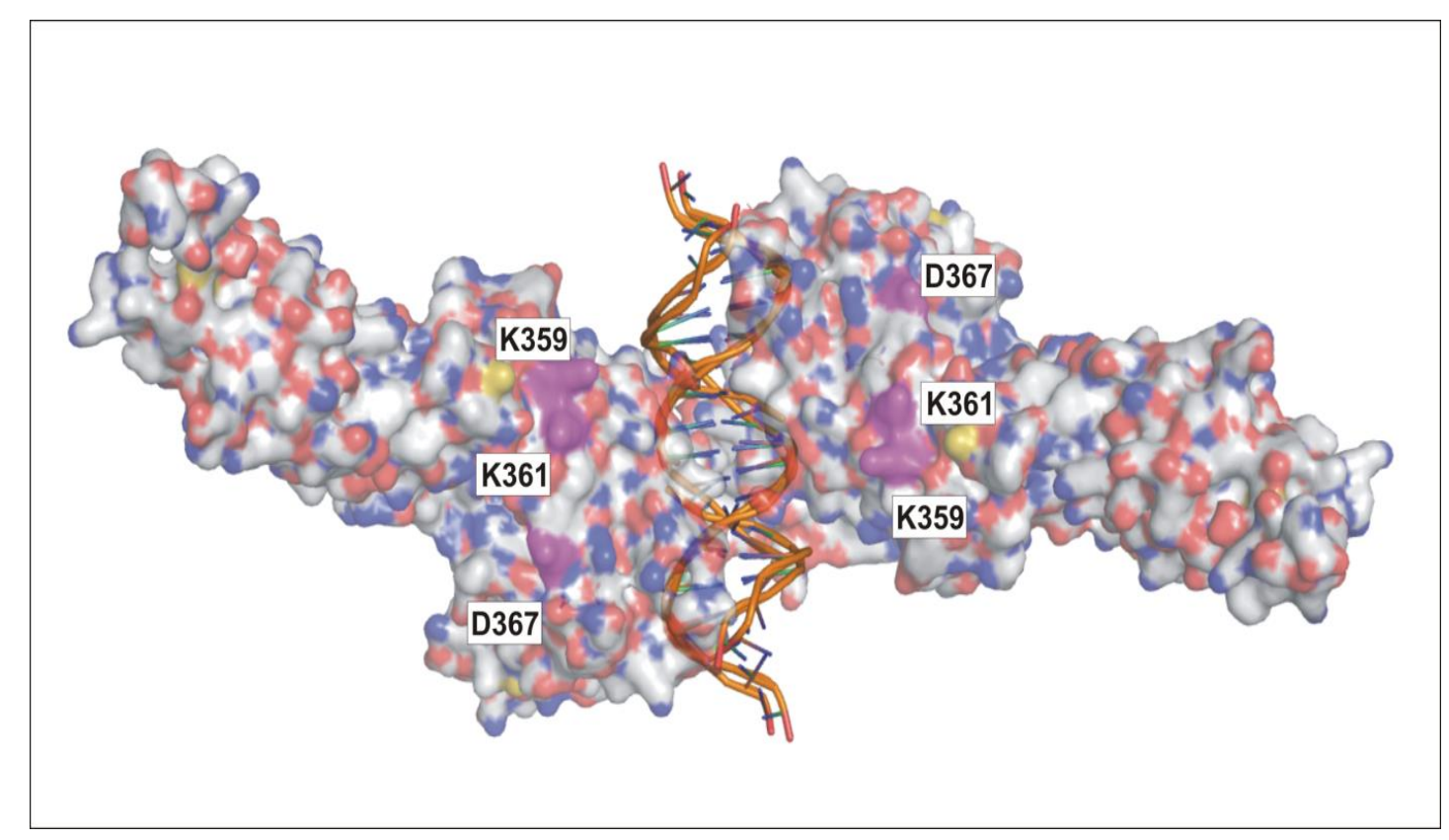


Abb. 21: Darstellung der Kristallstruktur eines DNA-gebundenen STAT1-Dimers mit den drei in dieser Arbeit untersuchten Punktmutanten. STAT1 ist als Dimer dargestellt und fest mit der DNA verbunden. In lila dargestellt sind die Mutationen zu erkennen, die jeweils mit der Nummer der Aminosäure beschriftet sind.

Diese Aminosäurereste liegen ganz in der Nähe von R378 und K336, die nachweislich mit der DNA interagieren (Chen et al. 1998). Diese Tatsache unterstützt die Vermutung, dass auch die für diese Arbeit mutierten Reste Einfluss auf die DNA-Bindung haben könnten, obwohl sie sich in einiger Entfernung zur DNA befinden. Der Sequenzvergleich aller humanen STAT-Mitglieder identifizierte, wie bereits erwähnt, einen konservierten Lysinrest in Position 359 im STAT1-Molekül.

\begin{tabular}{l|l|l|l|l|l|l|l|l|l|l|l|l|l|l|l} 
STAT1 & 358 & $\mathrm{~L}$ & $\mathrm{~K}$ & & & & $\mathrm{~V}$ & $\mathrm{~K}$ & $\mathrm{~V}$ & $\mathrm{I}$ & $\mathrm{F}$ & $\mathrm{D}$ & $\mathrm{K}$ & $\mathrm{D}$ & 367 \\
\hline STAT3 & 362 & $\mathrm{~L}$ & $\mathrm{~K}$ & & & & $\mathrm{I}$ & $\mathrm{K}$ & $\mathrm{V}$ & $\mathrm{C}$ & $\mathrm{I}$ & $\mathrm{D}$ & $\mathrm{K}$ & $\mathrm{D}$ & 371 \\
\hline STAT4 & 358 & $\mathrm{~V}$ & $\mathrm{~K}$ & & & & $\mathrm{~V}$ & $\mathrm{~K}$ & $\mathrm{~A}$ & $\mathrm{~S}$ & $\mathrm{I}$ & $\mathrm{D}$ & $\mathrm{K}$ & $\mathrm{N}$ & 367 \\
\hline STAT5a & 364 & $\mathrm{M}$ & $\mathrm{N}$ & $\mathrm{P}$ & $\mathrm{P}$ & $\mathrm{Q}$ & $\mathrm{V}$ & $\mathrm{K}$ & $\mathrm{A}$ & $\mathrm{T}$ & $\mathrm{I}$ & $\mathrm{I}$ & $\mathrm{S}$ & $\mathrm{E}$ & 377 \\
\hline STAT5b & 364 & $\mathrm{M}$ & $\mathrm{N}$ & $\mathrm{P}$ & $\mathrm{P}$ & $\mathrm{Q}$ & $\mathrm{V}$ & $\mathrm{K}$ & $\mathrm{A}$ & $\mathrm{T}$ & $\mathrm{I}$ & $\mathrm{I}$ & $\mathrm{S}$ & $\mathrm{E}$ & 377 \\
\hline STAT6 & 306 & $\mathrm{~A}$ & $\mathrm{~K}$ & $\mathrm{P}$ & $\mathrm{P}$ & $\mathrm{L}$ & $\mathrm{V}$ & $\mathrm{R}$ & $\mathrm{A}$ & $\mathrm{D}$ & $\mathrm{M}$ & $\mathrm{V}$ & $\mathrm{T}$ & $\mathrm{E}$ & 318
\end{tabular}

In den Mitgliedern der humanen STAT-Familie STAT1, STAT3, STAT4 und STAT6, befindet sich in der homologen Position ein Lysinrest mit bekanntermaßen polarer Seitenkette. Dies gilt ebenso für die Position 361 von STAT1, wobei hier STAT5a und $b$ anstelle von STAT6 den positiv geladenen Lysinrest enthalten.

In den Experimenten, die in dieser Arbeit vorgestellt werden, ist auf die transkriptionelle Leistung der einzelnen Mutanten eingegangen worden. In den in Abbildung 20 dargetellten RT-PCR-Versuchen blieb die Expression der Zielgene irf1, gpb1, und mig1 mit einer klassischen singulären Gamma-aktivierten Stelle durch die Mutation unverändert. Auch die Phosphorylierung wurde näher untersucht. In anderen Arbeiten konnten bereits Hypo- oder Hyperphosphorylierungen von Punktmutanten in der DNA-Bindedomäne festgestellt werden (Meyer et al., 2003). Diese Eigenschaften können unterschiedliche Ursachen haben. Hat die Mutante zum Beispiel einen Import-Defekt kann dies unter Umständen zur Hyperphosphorylierung führen, doch sollte in diesem Fall die DNA-Bindung nicht per se beeinträchtigt sein. 
STAT1 ist im unstimulierten Zustand hauptsächlich im Zytoplasma lokalisiert. Kommt es jedoch zur Zytokinstimulation, erfährt der größte Teil des STAT1 eine Translokation in den Nukleus. Dieser Vorgang bedarf allerdings bestimmter Transportmechanismen, da die Moleküle dieser Größe gewöhnlich nicht dazu im Stande sind, die Kernmembran allein durch freie Diffusion zu überwinden (Paine und Feldherr 1972; Weis 1998). Durch einen Import-Defekt einer STAT1-Mutante könnte beispielsweise der Transport in den Zellkern im Vergleich zum STAT1-WT verringert bzw. verhindert werden. Um eine solche Mutante zu generieren, sollte sich die Mutation in einer Region mit einem nukleären Lokalisationssignal befinden. Diese Überlegung wurde in anderen Arbeiten bereits wissenschaftlich verfolgt, da die Tatsache, dass das nukleäre Lokalisationssignal die Bindung von STAT1-Dimeren an Importin-a5 ermöglicht und somit für die Kernakkumulation von großer Bedeutung ist, bereits erforscht worden ist (Fagerlund et al. 2002; McBride et al. 2002; Meyer et al. 2002). Ist der nukleäre Import von STAT1-Mutanten beeinträchtigt, sind sie entsprechend vermehrt im Zytosol vertreten und dort der Phosphatase-Aktivität verringert, der Kinase-Aktivität aber verstärkt ausgesetzt. In diesem Fall würde sich die Konzentration von Tyrosinphosphorylierten STAT1-Dimeren im Zytoplasma stark erhöhen und sie würden verstärkt zu einem Substrat der Kinasen werden. Beobachtet würde in einem solchen Fall eine Hyperphosphorylierung von STAT1, ausgelöst durch eine funktionell beeinträchtigende Punktmutation in der Region des in der DNA-Bindedomäne befindlichen nukleären Lokalisationssignals (Meyer et al 2002).

Im Hinblick auf das Wildtyp-Molekül wird deutlich, dass sich Veränderungen des DNA-Bindeverhaltens in geänderter transkriptionellen Aktivität und geänderter Kinetik der Tyrosin-Dephosphorylierung widerspiegeln. Gelänge es, eine STAT1-Mutante zu entwickeln, die eine signifikant höhere transkriptionelle Leistung besitzt, so könnte dies von großer Bedeutung sein. Ein Beispiel hierfür ist die Möglichkeit, neue Wirkstoffe testen zu können und dieses könnte im Hinblick auf eine pharmakologische Steuerung der Immunregulation therapeutisch durchaus sinnvoll sein. Allerdings besteht hier die Gefahr, in Mechanismen der natürlichen Infektionsabwehr einzugreifen mit möglichen nachteiligen Folgen für den gesamten Organismus. Liegt ein Transkriptionssignal länger als normal in aktiviertem Zustand vor, so reagiert das System womöglich weniger flexibel auf Abweichungen der extrazellulären IFNYKonzentration. 
Bekannt ist, dass DNA-Bindung Tyrosin-phosphorylierte STAT1-Moleküle vor Dephos-phorylierung schützt (Meyer et al. 2003; Meyer et al. 2004). Eine Veränderung der Dissoziationskinetik als Folge einer erniedrigten Dissoziationsrate von DNA könnte ebenfalls eine Erklärung für eine Hyperphosphorylierung sein. Die Phosphorylierung, wie in Abbildung 6 ersichtlich, wurde in Western-Blot-Versuchen untersucht und erbrachte für die hier charakterisierten Mutanten keine signifikanten Unterschiede zum Wildtyp-Molekül. Gibt es Abweichungen in der Phosphorylierung, könnte dieses womöglich auf abnormale Bindungsaffinität zu GAS-enthaltenden Sonden hinweisen. Dies ließ sich in den durchgeführten Gelshift-Versuchen jedoch nicht bestätigen, da weder in der Phosphorylierung (zum Beispiel in Abbildung 6) noch in der Bindungsaffinität zu GAS-Sonden (zum Beispiel in Abbildung 16) bemerkenswerte Abweichungen zwischen dem STAT1-WT und den drei in dieser Arbeit erzeugten Mutanten festgestellt werden konnten. Auch in weiteren EMSA-Experimenten blieben die Unterschiede zwischen den verschieden STAT1-Varianten aus.

Eine naheliegende Erklärung für die fehlende Änderung in der DNA-Bindekinetik trotz der Mutation konservierter Aminosäurereste ist, dass es nicht zur direkten Interaktion der mutierten Aminisäurereste mit der DNA kommt. Möglicherweise ist andererseits der Bindebeitrag so gering bzw. sind die Methoden nicht sensitiv genug, um geringgradige Auswirkungen auf die DNA-Bindung zu erkennen. Wie bereits in der Einleitung angedeutet, verwenden die STATs, um an die DNA binden zu können, eine Immunglobulin-Faltung, die derjenigen von NF-KB und p53 sehr ähnlich ist. Auffällig sind die vergleichbaren Bindemotive bei den STATs sowie bei NF-KB, wobei sie trotz aller Ähnlichkeiten grundlegende Unterschiede in ihrem Mechanismus aufweisen. Durch Studien an NF-KB wurde deutlich, dass eine Kernverlagerung auch durch Bindung an einen Hemmstoff mit Exposition von Kernlokalisationssignalen und anschließender Verlagerung in den Nukleus einhergehen kann. Dies ist bei den STATs bisher nicht detektiert worden. Die Tyrosin-Phosphorylierung und Dimerisierung stehen weiterhin als Bindemechanismus an erster Stelle, wobei der genaue Hergang der folgenden Kernverlagerung noch immer nicht vollständig geklärt werden konnte (Chen et al. 1998).

Die in Abb. 8 und 10 dargestellten Versuche beschäftigen sich mit der Akkumulation im Nukleus. Durch einen gestörten Kerntransport könnte es möglicherweise zu einer verminderten Kernlokalisation kommen. Dies begründet sich dadurch, dass phosphorylierte STAT-Dimere mit Importin-a5 vermittelt über ein dimerspezifisches NLS inter- 
agieren müssen. Dieses Lokalisationssignal ist nur bei paralleler Konformation der phosphorylierten STAT1-Dimere zugänglich (Fagerlund et al. 2002; Melén et al. 2001; Meyer et al. 2002). Mutationen in der DNA-Bindemutante könnten möglicherweise dazu führen, dass sich dieser Mechanismus verändert. Generell kann jede Veränderung der flexiblen Domänenarchitektur mit einer Störung der STAT-vermittelten Signaltransduktion in Verbindung gebracht werden. Solche mutationsbedingten Destabilisierungen der parallelen Konformation von phosphorylierten STAT1-Dimeren drücken sich schließlich in einer geänderten Aktivierung von IFNY-gesteuerten Zielgenen aus. Dies kann zum Beispiel durch Hypophosphorylierung zu einer verminderten Genexpression führen. Um dem entgegenzuwirken, kann das Gleichgewicht in Richtung einer antiparallelen Ausrichtung verlagert werden. Demnach bedarf es bei der JAK-STAT-Signalweiterleitung keiner festen Molekülstruktur der dimeren STAT1Moleküle, sondern vielmehr der Flexibilität, ein transkriptionell aktives STAT1-Dimer bilden bzw. wieder lösen zu können. Hierbei ist es wichtig, dass ein dynamischer Wechsel zwischen den beiden Dimer-Konfigurationen besteht. Der Schwerpunkt liegt demnach weder auf der parallelen noch der antiparallelen Konfiguration, sondern beide sind von essentieller Bedeutung. Insgesamt unterscheidet man zwei verschiedene Konformationen der Tyrosin-phosphorylierten STAT-Dimere. Bei den Homodimeren sind in der parallelen Konfiguration die SH2-Domänen immer in gleicher Richtung orientiert, was für die Rezeptor- und die DNA-Bindung von wesentlicher Bedeutung ist (Mao et al. 2005; Mertens et al. 2006). Lösen sich die Tyrosinphosphorylierten STAT1-Dimere von der DNA, müssen sie eine antiparallele Orientierung einnehmen, damit sie von der TC45-Phosphatase erkannt und dephosphoryliert werden können. Dieser Dephosphorylierungsvorgang ist unerlässlich, um mithilfe von Transportmechanismen die Kernmembran überwinden zu können (Meyer et al. 2003). Bei Betrachtung der antiparallelen Konformation zeigen die SH2-Domänen in die entgegengesetzte Richtung. Die Stabilisierung hierbei wird durch Interaktionen der Coiled-coil-Domäne mit der DNA-Bindedomäne sowie möglicherweise auch durch ND:ND-Wechselwirkungen gewährleistet (Zhong et al. 2005; Mertens et al. 2006).

Der Mechanismus der Konformationsänderung von phosphorylierten STAT1-Dimeren ist bis heute jedoch noch nicht umfassend erforscht. Für das Verständnis des Konformationswechsels im Detail bedarf es noch weiterer Experimente. Es bestand die Möglichkeit, dass die Mutation der Aminosäuren den Konformationswechsel des Di- 
mers beeinträchtigt. Dies hätte sich dann in Versuch 8 in einer Abweichung des Kerntransportes des STAT1-WT vom Kerntransport der Mutanten niederschlagen müssen. Diese Vermutung konnte jedoch nicht verifiziert werden.

Der Tatsache zum Trotz, dass die mutierten Aminosäurereste dieser Arbeit konserviert sind, konnte mit den durchgeführten Experimenten jedenfalls keine Abweichung zum STAT1-WT festgestellt werden. Die vermutete Beteiligung an der DNA-Bindung bestätigte sich nicht. Es ist jedoch möglich, dass dies durch weitere Experimente mit DNA-Affinitätsmessungen (zum Beispiel mit Thermofluor, Pull-down-Assays, Fluoreszenz-Anisotropie) gezeigt werden könnte, etwa in einer KristallstrukturBestimmung des STAT-Proteins im Komplex mit anderen DNAs. Da die STAT-Familie aus vielen Mitgliedern besteht, kann ebenfalls vermutet werden, dass die Konservierung für die anderen Mitglieder von weiterer Bedeutung sein könnte, es bei STAT1 jedoch nur noch eine Frage der Zeit ist, bis es an den konservierten Positionen zu Mutationen kommt. Möglicherweise besteht die Konservierung jedoch aus einem ganz anderen Grund als dem der DNA-Bindung. Beispielsweise könnten die Aminosäuren an den Positionen 359, 361 und 367 bei der Faltung des Proteins von Bedeutung sein oder die Interaktion mit anderen Aminosäuren in den STATs sorgt für eine stabile 3D-Struktur.

Da der JAK-STAT-Kinaseweg als Signalübertragungsmechanismus bei der Zellentwicklung, der Homöostase und auch bei der Wachstumskontrolle eine wesentliche Rolle spielt, ist die Aufklärung der physiologischen Rolle konservierter Aminosäurereste von berechtigtem Interesse. Zusammenfassend wird deutlich, dass nicht jeder Austausch konservierter Aminosäurereste mit einem messbar veränderten Verhalten der Mutanten verbunden sein muss. Die Mutanten dieser Arbeit jedenfalls zeigen keine nachweisbar signifikanten Veränderungen gegenüber dem WildtypMolekül. 


\section{Zusammenfassung}

Der Signaltransduktor und Aktivator der Transkription 1 (STAT1) ist ein Mitglied der konservierten Proteinfamilie von zytokinregulierten Transkriptionsfaktoren und spielt bei vielen biologischen Prozessen, wie beispielsweise der Steuerung der Immunantwort und der Zellproliferation, eine entscheidende Rolle. Bei Stimulation der Zellen mit Interferon- $\gamma$ (IFN $\gamma$ ) phosphorylieren rezeptorassoziierte JAK-Kinasen einen kritischen Tyrosinrest im Carboxyterminus von STAT1. Die Tyrosin-phosphorylierten STAT1-Homodimere akkumulieren daraufhin im Zellkern, wo sie spezifische Bindestellen in den Promotoren von STAT1-abhängigen Zielgenen erkennen. In der vorliegenden Arbeit wurde untersucht, ob drei oberflächenexponierte und konservierte Aminosäurereste in der DNA-Bindedomäne (Lys 359, Lys 361 und Asp 367) an der Weiterleitung der Signalintensität beteiligt sind. Zu diesem Zweck führte ich einen Mutageneseansatz durch und substituierte die drei Aminosäurerreste zu Alaninen, doch keiner der drei erhaltenen Punktmutanten zeigte eine gegenüber dem WildtypMolekül geänderte Kinetik der Tyrosin-Phosphorylierung, der induzierbaren Kernakkumulation sowie der Dissoziation von hochaffinen DNA-Bindestellen. Auch blieben die transkriptionelle Aktivierung eines Reportergenkonstrukts und die Expression von sämtlichen der untersuchten IFN $\gamma$-abhängigen endogenen Zielgene durch die Mutationen unverändert. Zusammendfassend fand ich keine Unterschiede im detektierbaren Verhalten der Mutanten gegenüber dem Wildtyp-Molekül. Doch kann nicht ausgeschlossen werden, dass sich Änderungen in den hier nicht erfassten nichtkanonischen STAT1-Funktionen ergeben könnten, die kausal für die Homologie dieser Reste verantwortlich sind. 


\subsection{Summary}

Signal transducer and activator of transcription 1 (STAT1) is a member of the conserved protein family of cytokine-regulated transcription factors and plays a decisive role in many biological processes such as the control of the immune response and cell proliferation. Upon stimulation of the cells with interferon- $\gamma$ (IFN $\gamma$ ), receptorassociated JAK kinases phosphorylate a signature tyrosine residue in the carboxyterminus of STAT1. Tyrosine-phosphorylated STAT1 homodimers then accumulate in the nucleus, where they recoginze specific binding sites in the promoters of STAT1dependent target genes. In the present study, it was investigated whether three surface-exposed and conserved amino acid residues in the DNA-binding domain (Lys 359, Lys 361, and Asp 367) are involved in the transduction of IFN $\gamma$-mediated signal intensity. For this purpose, I performed a mutagenesis approach and substituted the three amino acid residues to alanines. However, none of the three resulting point mutants exhibited altered kinetics of tyrosine phosphorylation, inducible nuclear accumulation or dissociation from high-affinity binding sites on DNA as compared to the wildtype molecule. Similarly, the transcriptional activation of a reporter gene construct and expression of numerous investigated IFN $\gamma$-dependent endogenous target genes were unaffected by the mutations. In summary, I found no detectable differences in the behavior of the mutants when compared to the wild-type molecule. However, the possibility cannot be excluded that unrecognized changes in non-canonical STAT1 functions accounted for the conserved homology of these residues. 


\section{Literaturverzeichnis}

Aguet M, Dembić Z, Merlin G (1988): Molecular cloning and expression of the human interferon-gamma receptor. Cell $\underline{55}, 273-280$

Akira S (1999): Functional roles of STAT family proteins: lessons from knockout mice. Stem Cells 17, 138-146

Alonzi T, Maritano D, Gorgoni B, Rizzuto G, Libert C, Poli V (2001): Essential role of STAT3 in the control of the acute-phase response as revealed by inducible gene inactivation [correction of activation] in the liver. Mol Cell Biol 21, 1621-1632

Araki T, Kawata T, Williams JG (2012): Identification of the kinase that activates a nonmetazoan STAT gives insights into the evolution of phosphotyrosine-SH2 domain signaling. Proc Natl Acad Sci USA 109, E1931-7

Bach EA, Aguet M, Schreiber RD (1997): The IFN gamma receptor: a paradigm for cytokine receptor signaling. Annu Rev Immunol $\underline{15}, 563-591$

Baden HA, Sarma SP, Kapust RB, Byrd RA, Waugh DS (1998): The aminoterminal domain of human STAT4. Overproduction, purification, and biophysical characterization. J Biol Chem $\underline{273}, 17109-17114$

Barillas-Mury C, Han YS, Seeley D, Kafatos FC (1999): Anopheles gambiae AgSTAT, a new insect member of the STAT family, is activated in response to bacterial infection. EMBO J $\underline{18}, 959-967$

Bazan JF (1989): A novel family of growth factor receptors: a common binding domain in the growth hormone, prolactin, erythropoietin and IL-6 receptors, and the p75 IL-2 receptor beta-chain. Biochem Biophys Res Commun 164, 788-795

Becker S, Groner B, Müller CW (1998): Three-dimensional structure of the Stat3beta homodimer bound to DNA. Nature $\underline{394}, 145-151$ 
Begitt A, Meyer T, van Rossum M, Vinkemeier U (2000): Nucleocytoplasmic translocation of Stat1 is regulated by a leucine-rich export signal in the coiled-coil domain. Proc Natl Acad Sci USA 97, 10418-10423

Boehm U, Klamp T, Groot M, Howard JC (1997): Cellular responses to interferongamma. Annu Rev Immunol 15, 749-795

Bork P, Holm L, Sander C (1994): The immunoglobulin fold. Structural classification, sequence patterns and common core. J Mol Biol 242, 309-320

Briscoe J, Rogers NC, Witthuhn BA, Watling D, Harpur AG, Wilks AF, Stark GR, Ihle JN, Kerr IM (1996): Kinase-negative mutants of JAK1 can sustain interferongamma-inducible gene expression but not an antiviral state. EMBO J $\underline{15}, 799-809$

Chang CH, Hammer J, Loh JE, Fodor WL, Flavell RA (1992): The activation of major histocompatibility complex class I genes by interferon regulatory factor-1 (IRF-1). Immunogenetics $\underline{35}, 378-384$

Chen X, Vinkemeier U, Zhao Y, Jeruzalmi D, Darnell JE, Kuriyan J (1998): Crystal structure of a tyrosine phosphorylated STAT-1 dimer bound to DNA. Cell $\underline{93}, 827-$ 839

Chen X, Bhandari R, Vinkemeier U, van Den Akker F, Darnell JE, Kuriyan J (2003): A reinterpretation of the dimerization interface of the N-terminal domains of STATs. Protein Sci 12, 361-365

Cironimo NM, Li GY, Xiao W, Torrence PF, Silverman RH (1997): Targeting RNA decay with 2',5' oligoadenylate-antisense in respiratory syncytial virus-infected cells. Proc Natl Acad Sci USA 94, 1937-1942

Copeland NG, Gilbert DJ, Schindler C, Zhong Z, Wen Z, Darnell JE, Mui AL, Miyajima A, Quelle FW, Ihle JN, Jenkins NA (1995): Distribution of the mammalian Stat gene family in mouse chromosomes. Genomics $\underline{29}$, 225-228 
Darnell JE (1997): STATs and gene regulation. Science $\underline{277}, 1630-1635$

Darnell JE, Kerr IM, Stark GR (1994): Jak-STAT pathways and transcriptional activation in response to IFNs and other extracellular signaling proteins. Science $\underline{264}$, $1415-1421$

Decker T, Lew DJ, Mirkovitch J, Darnell JE (1991): Cytoplasmic activation of GAF, an IFN-gamma-regulated DNA-binding factor. EMBO J $\underline{10}$, 927-932

Decker T, Kovarik P, Meinke A (1997): GAS elements: a few nucleotides with a major impact on cytokine-induced gene expression. J Interferon Cytokine Res 17, 121134

Diaz-Guerra M, Rivas C, Esteban M (1997): Inducible expression of the 2-5A synthetase/RNase $L$ system results in inhibition of vaccinia virus replication. Virology $\underline{227}, 220-228$.

Durbin JE, Hackenmiller R, Simon MC, Levy DE (1996): Targeted disruption of the mouse Stat 1 gene results in compromised innate immunity to viral disease. Cell $\underline{84}$, $443-450$

Fagerlund R, Melén K, Kinnunen L, Julkunen I (2002): Arginine/lysine-rich nuclear localization signals mediate interactions between dimeric STATs and importin alpha 5. J Biol Chem $\underline{277}$, 30072-30078

Fahrenkrog B, Köser J, Aebi U (2004): The nuclear pore complex: a jack of all trades? Trends Biochem Sci $\underline{29}, 175-182$

Frese M, Kochs G, Feldmann H, Hertkorn C, Haller O (1996): Inhibition of bunyaviruses, phleboviruses, and hantaviruses by human MxA protein. J Virol $\underline{70}, 915-923$

Fu XY (1992): A transcription factor with SH2 and SH3 domains is directly activated by an interferon alpha-induced cytoplasmic protein tyrosine kinase(s). Cell $\underline{70}$, 323335 
Gao B (2005): Cytokines, STATs and liver disease. Cell Mol Immunol 2, 92-100

Gao Q, Hua J, Kimura R, Headd JJ, Fu X, Chin YE (2004): Identification of the linker-SH2 domain of STAT as the origin of the SH2 domain using two-dimensional structural alignment. Mol Cell Proteomics $\underline{3}, 704-714$

Görlich D, Kostka S, Kraft R, Dingwall C, Laskey RA, Hartmann E, Prehn S (1995): Two different subunits of importin cooperate to recognize nuclear localization signals and bind them to the nuclear envelope. Curr Biol $\underline{5}, 383-392$

Greenlund AC, Morales MO, Viviano BL, Yan H, Krolewski J, Schreiber RD (1995): Stat recruitment by tyrosine-phosphorylated cytokine receptors: an ordered reversible affinity-driven process. Immunity $\underline{2}, 677-687$

Gupta S, Yan H, Wong LH, Ralph S, Krolewski J, Schindler C (1996): The SH2 domains of Stat1 and Stat2 mediate multiple interactions in the transduction of IFN- $\alpha$ signals. EMBO J 15, 1075-1084

ten Hoeve J, de Jesus Ibarra-Sanchez M, Fu Y, Zhu W, Tremblay M, David M, Shuai K (2002): Identification of a nuclear Stat1 protein tyrosine phosphatase. Mol Cell Biol 2, 5662-5668

Hoey T, Schindler U (1998): STAT structure and function in signalling. Curr Opin Genet Dev $\underline{8}, 582-587$

Horvath CM (2000): STAT proteins and transcriptional responses to extracellular signals. Trends Biochem Sci $\underline{25}$, 496-502

Horvath CM, Darnell JE (1996): The antiviral state induced by alpha interferon and gamma interferon requires transcriptionally active Stat 1 protein. J Virol $\underline{70}, 647-650$ 
Horvath CM, Wen Z, Darnell JE (1995): A STAT protein domain that determines DNA sequence recognition suggests a novel DNA-binding domain. Genes Dev $\underline{9}$, 984-994

Ihle JN, Kerr IM (1995): Jaks and Stats in signaling by the cytokine receptor superfamily. Trends Genet $\underline{11}, 69-74$

Isaacs A, Lindenmann J (1987): Virus interference. I. The interferon. By A. Isaacs and J. Lindenmann, 1957. J Interferon Res $\underline{7}$, 429-438

Janjua S, Stephanou A, Latchman DS (2002): The C-terminal activation domain of the STAT-1 transcription factor is necessary and sufficient for stress-induced apoptosis. Cell Death Differ $\underline{9}, 1140-1146$

John S, Vinkemeier U, Soldaini E, Darnell JE, Leonard WJ (1999): The significance of tetramerization in promoter recruitment by Stat5. Mol Cell Biol 19, 19101918

Kaplan MH, Schindler U, Smiley ST, Grusby MJ (1996a): Stat6 is required for mediating responses to IL-4 and for development of Th2 cells. Immunity $4,313-319$

Kaplan MH, Sun YL, Hoey T, Grusby MJ (1996b): Impaired IL-12 responses and enhanced development of Th2 cells in Stat4-deficient mice. Nature $\underline{382}, 174-177$

Kawata T, Shevchenko A, Fukuzawa M, Jermyn KA, Totty NF, Zhukovskaya NV, Sterling AE, Mann M, Williams JG (1997): SH2 signaling in a lower eukaryote: a STAT protein that regulates stalk cell differentiation in dictyostelium. Cell $\underline{89}, 909$ 916

Koch CA, Anderson D, Moran MF, Ellis C, Pawson T (1991): SH2 and SH3 domains: elements that control interactions of cytoplasmic signaling proteins. Science $\underline{252}, 668-674$ 
Kuriyan J, Cowburn D (1997): Modular peptide recognition domains in eukaryotic signaling. Annu Rev Biophys Biomol Struct 26, 259-288

Langer JA, Pestka S (1988): Interferon receptors. Immunol Today $\underline{9}$, 393-400

Leaman DW, Pisharody S, Flickinger T, Commane MA, Schlessinger J, Kerr IM, Levy DE, Stark GR (1996): Roles of JAKs in activation of STATs and stimulation of c-fos Gene expression by epidermal growth factor. Mol Cell Biol 16, 369-375

Leung S, Li X, Stark GR (1996). STATs find that hanging together can be stimulating. Science $\underline{273}, 750-751$

Levy DE, Darnell JE (1990): Interferon-dependent transcriptional activation: signal transduction without second messenger involvement? New Biol 2, 923-928

Levy DE, Darnell JE (2002): Stats: transcriptional control and biological impact. Nat Rev Mol Cell Biol $\underline{3}, 651-662$

Liao J, Fu Y, Shuai K (2000): Distinct roles of the NH2- and $\mathrm{COOH}$-terminal domains of the protein inhibitor of activated signal transducer and activator of transcription (STAT) 1 (PIAS1) in cytokine-induced PIAS1-Stat1 interaction. Proc Natl Acad Sci USA $\underline{97}, 5267-5272$

Litterst CM, Pfitzner E (2001): Transcriptional activation by STAT6 requires the direct interaction with NCoA-1. J Biol Chem 276, 45713-45721

Liu L, McBride KM, Reich NC (2005): STAT3 nuclear import is independent of tyrosine phosphorylation and mediated by importin- $\alpha 3$. Proc Natl Acad Sci USA 102, 8150-8155

Liu X, Robinson GW, Wagner KU, Garrett L, Wynshaw-Boris A, Hennighausen L (1997): Stat5a is mandatory for adult mammary gland development and lactogenesis. Genes Dev $\underline{11}, 179-186$ 
Liu X, Quinn AM, Chin YE, Fu XY (1999): STAT Genes Found in C. elegans. Science $\underline{285}, 167 \mathrm{a}$

Lufei C, Ma J, Huang G, Zhang T, Novotny-Diermayr V, Ong CT, Cao X (2003): GRIM-19, a death-regulatory gene product, suppresses Stat3 activity via functional interaction. EMBO J $\underline{22}, 1325-1335$

Mao X, Ren Z, Parker GN, Sondermann H, Pastorello MA, Wang W, McMurray JS, Demeler B, Darnell JE, Chen X (2005): Structural bases of unphosphorylated STAT1 association and receptor binding. Mol Cell 17, 761-771

Mayer BJ, Hanafusa $\mathrm{H}$ (1990): Association of the v-crk oncogene product with phosphotyrosine-containing proteins and protein kinase activity. Proc Natl Acad Sci USA 87, 2638-2642

Mayer BJ, Jackson PK, Baltimore D (1991): The noncatalytic src homology region 2 segment of abl tyrosine kinase binds to tyrosine-phosphorylated cellular proteins with high affinity. Proc Natl Acad Sci USA $\underline{88}, 627-631$

McBride KM, Banninger G, McDonald C, Reich NC (2002): Regulated nuclear import of the STAT1 transcription factor by direct binding of importin-alpha. EMBO J $\underline{21}$, 1754-1763

Meissner T, Krause E, Lödige I, Vinkemeier U (2004): Arginine methylation of STAT1: a reassessment. Cell $\underline{119}, 587-589$

Melén K, Kinnunen L, Julkunen I (2001): Arginine/lysine-rich structural element is involved in interferon-induced nuclear import of STATs. J Biol Chem $\underline{276}, 16447-$ 16455

Meraz MA White JM, Sheehan KC, Bach EA, Rodig SJ, Dighe AS, Kaplan DH,Riley K, Greenlund AC, Campbell D, Carver-Moore K, DuBois RN, Clark R, Aguet M, Schreiber RD (1996): Targeted disruption of the Stat1 gene in mice re- 
veals unexpected physiologic specificity in the JAK-STAT signaling pathway. Cell $\underline{84}$, $431-442$

Mertens C, Zhong M, Krishnaraj R, Zou W, Chen X, Darnell JE (2006): Dephosphorylation of phosphotyrosine on STAT1 dimers requires extensive spatial reorientation of the monomers facilitated by the N-terminal domain. Genes Dev $\underline{20}$, 3372-3381

Meurs EF, Watanabe Y, Kadereit S, Barber GN, Katze MG, Chong K, Williams BR, Hovanessian AG (1992): Constitutive expression of human double-stranded RNA-activated p68 kinase in murine cells mediates phosphorylation of eukaryotic initiation factor 2 and partial resistance to encephalomyocarditis virus growth. J Virol $\underline{66}, 5805-5814$

Meyer T, Begitt A, Lödige I, van Rossum M, Vinkemeier U (2002): Constitutive and IFN-gamma-induced nuclear import of STAT1 proceed through independent pathways. EMBO J 21 , 344-354

Meyer T, Marg A, Lemke P, Wiesner B, Vinkemeier U (2003): DNA binding controls inactivation and nuclear accumulation of the transcription factor Stat1. Genes Dev 17, 1992-2005

Meyer T, Hendry L, Begitt A, John S, Vinkemeier U (2004): A single residue modulates tyrosine dephosphorylation, oligomerization, and nuclear accumulation of stat transcription factors. J Biol Chem 279, 18998-19007

Mui AL, Wakao H, O'Farrell AM, Harada N, Miyajima A (1995): Interleukin-3, granulocyte-macrophage colony stimulating factor and interleukin-5 transduce signals through two STAT5 homologs. EMBO J $\underline{14}, 1166-1175$

Murphy TL, Geissal ED, Farrar JD, Murphy KM (2000): Role of the Stat4 N domain in receptor proximal tyrosine phosphorylation. Mol Cell Biol 20, 7121-7131 
Nicola NA (1994): Cytokine pleiotropy and redundancy: a view from the receptor. Stem Cells $\underline{12}, 3-12$

Nigg EA (1997): Nucleocytoplasmic transport: signals, mechanisms and regulation. Nature $\underline{386}, 779-787$

Novick D, Cohen B, Rubinstein M (1994): The human interferon alpha/beta receptor: characterization and molecular cloning. Cell $\underline{77}, 391-400$

Oates AC, Wollberg P, Pratt SJ, Paw BH, Johnson SL, Ho RK, Postlethwait JH, Zon LI Wilks AF (1999): Zebrafish stat3 is expressed in restricted tissues during embryogenesis and stat1 rescues cytokine signaling in a STAT1-deficient human cell line. Dev Dyn 215, 352-370

O'Shea JJ (1997): Jaks, STATs, cytokine signal transduction, and immunoregulation: Are we there yet? Immunity $\underline{7}, 1-11$

Ouchi T, Lee SW, Ouchi M, Aaronson SA, Horvath CM (2000): Collaboration of signal transducer and activator of transcription 1 (STAT1) and BRCA1 in differential regulation of IFN-gamma target genes. Proc Natl Acad Sci U S A $\underline{97}$, 5208-5213

Paine PL, Feldherr CM (1972): Nucleocytoplasmic exchange of macromolecules. Exp Cell Res $\underline{74}, 81-98$

Park C, Li S, Cha E, Schindler C (2000): Immune response in Stat2 knockout mice. Immunity $\underline{13}, 795-804$

Pascal A, Riou JF, Carron C, Boucaut JC, Umbhauer M (2001): Cloning and developmental expression of STAT5 in Xenopus laevis. Mech Dev 106, 171-174

Pawson T (1988): Non-catalytic domains of cytoplasmic protein-tyrosine kinases: regulatory elements in signal transduction. Oncogene $\underline{3}, 491-495$ 
Platanias LC (2005): Mechanisms of type-I- and type-II-interferon-mediated signaling. Nat Rev Immunol $\underline{5}, 375-386$

Radu A, Blobel G, Moore MS (1995a): Identification of a protein complex that is required for nuclear protein import and mediates docking of import substrate to distinct nucleoporins. Proc Natl Acad Sci U S A $\underline{92}$, 1769-1773

Radu A, Moore MS, Blobel G (1995b): The peptide repeat domain of nucleoporin Nup98 functions as a docking site in transport across the nuclear pore complex. Cell $\underline{81}, 215-222$

Revel M, Chebath J (1986): Interferon-activated genes. Trends in Biochemical Sciences $\underline{11}, 166-170$

Sadowski I, Stone JC, Pawson T (1986): A noncatalytic domain conserved among cytoplasmic protein-tyrosine kinases modifies the kinase function and transforming activity of Fujinami sarcoma virus P130gag-fps. Mol Cell Biol $\underline{6}$, 4396-4408

Sadowski HB, Shuai K, Darnell JE, Gilman MZ (1993): A common nuclear signal transduction pathway activated by growth factor and cytokine receptors. Science $\underline{261}$, 1739-1744

Schindler C, Darnell JE (1995): Transcriptional responses to polypeptide ligands: the JAK-STAT pathway. Annu Rev Biochem $\underline{64}, 621-651$

Schindler C, Fu XY, Improta T, Aebersold R, Darnell JE (1992a): Proteins of transcription factor ISGF-3: one gene encodes the 91-and 84-kDa ISGF-3 proteins that are activated by interferon alpha. Proc Natl Acad Sci U S A 89, 7836-7839

Schindler C, Shuai K, Prezioso VR, Darnell JE (1992b): Interferon-dependent tyrosine phosphorylation of a latent cytoplasmic transcription factor. Science $\underline{257}, 809$ 813 
Schindler U, Wu P, Rothe M, Brasseur M, McKnight SL (1995): Components of a Stat recognition code: evidence for two layers of molecular selectivity. Immunity $\underline{2}$, 689-697

Schooltink H, Rose-John S (2002): Cytokines as therapeutic drugs. J Interferon Cytokine Res $\underline{22}, 505-516$

Seger R, Krebs EG (1995): The MAPK signaling cascade. FASEB J $\underline{9}, 726-735$

Shankaran V, Ikeda H, Bruce AT, White JM, Swanson PE, Old LJ, Schreiber RD (2001): IFNgamma and lymphocytes prevent primary tumour development and shape tumour immunogenicity. Nature $\underline{410}, 1107-1111$

Shuai K (1999): The STAT family of proteins in cytokine signaling. Prog Biophys Mol Biol $\underline{71}, 405-422$

Shuai K (2000): Modulation of STAT signaling by STAT-interacting proteins. Oncogene $\underline{19}, 2638-2644$

Shuai K, Schindler C, Prezioso VR, Darnell JE (1992): Activation of transcription by IFN-gamma: tyrosine phosphorylation of a 91-kD DNA binding protein. Science $\underline{258}$, 1808-1812

Shuai K, Stark GR, Kerr IM, Darnell JE (1993a): A single phosphotyrosine residue of Stat91 required for gene activation by interferon-gamma. Science $\underline{261}, 1744-1746$

Shuai K, Ziemiecki A, Wilks AF, Harpur AG, Sadowski HB, Gilman MZ, Darnell JE (1993b): Polypeptide signalling to the nucleus through tyrosine phosphorylation of Jak and Stat proteins. Nature $\underline{366}, 580-583$

Shuai K, Horvath CM, Huang LH, Qureshi SA, Cowburn D, Darnell JE (1994): Interferon activation of the transcription factor Stat91 involves dimerization through SH2-phosphotyrosyl peptide interactions. Cell $\underline{76}, 821-828$ 
Shuai K, Liao J, Song MM (1996): Enhancement of antiproliferative activity of gamma interferon by the specific inhibition of tyrosine dephosphorylation of Stat1. Mol Cell Biol $\underline{16}, 4932-4941$

Stark GR, Kerr IM, Williams BR, Silverman RH, Schreiber RD (1998): How cells respond to interferons. Annu Rev Biochem 67, 227-264

Stephanou A, Latchman DS (2003): STAT-1: a novel regulator of apoptosis. Int J Exp Pathol 누, 239-244

Strehlow I, Schindler C (1998): Amino-terminal signal transducer and activator of transcription (STAT) domains regulate nuclear translocation and STAT deactivation. J Biol Chem $\underline{273}, 28049-28056$

Sung SC, Fan TJ, Chou CM, Leu JH, Hsu YL, Chen ST, Hsieh YC, Huang CJ (2003): Genomic structure, expression and characterization of a STAT5 homologue from pufferfish. Eur J Biochem 270, 239-252

Takeda K, Akira S (2000): STAT family of transcription factors in cytokine-mediated biological response. Cytokine Growth Factor Rev 11, 199-207

Takeda K, Tanaka T, Shi W, Matsumoto M, Minami M, Kashiwamura S, Nakanishi K, Nobuaki Y, Kishimoto T, Akira S (1996): Essential role of Stat6 in IL-4 signalling. Nature $\underline{380}, 627-630$

Takeda K, Kaisho T, Yoshida N, Takeda J, Kishimoto T, Akira S (1998): Stat3 activation is responsible for IL-6-dependent $T$ cell proliferation through preventing apoptosis: generation and characterization of $\mathrm{T}$ cell-specific Stat3-deficient mice. J Immunol 161, 4652-4660

Takeda K, Noguchi K, Shi W, Tanaka T, Matsumoto M, Yoshida N, Kishimoto T, Akira S (1997a): Targeted disruption of the mouse Stat3 gene leads to early embryonic lethality. Proc Natl Acad Sci U S A 94, 3801-3804 
Takeda K, Kishimoto T, Akira S (1997b): STAT6: its role in interleukin 4-mediated biological functions. J Mol Med $\underline{75}, 317-326$

Thierfelder WE, van Deursen JM, Yamamoto K, Tripp RA, Sarawar SR, Carson RT, Sangster MY, Vignali DAA, Doherty PC, Grosveld GC, Ihle JN (1996): Requirement for Stat4 in interleukin-12-mediated responses of natural killer and T cells. Nature $\underline{382}, 171-174$

Thomson A (1998): The cytokine handbook 3rd edn. Academic Press, San Diego

Udy GB, Towers RP, Snell RG, Wilkins RJ, Park SH, Ram PA, Waxman DJ, Davey HW (1997): Requirement of STAT5b for sexual dimorphism of body growth rates and liver gene expression. Proc Natl Acad Sci U S A 94, 7239-7244

Vinkemeier U, Cohen SL, Moarefi I, Chait BT, Kuriyan J, Darnell JE (1996): DNA binding of in vitro activated Stat1 $\alpha$, Stat $1 \beta$ and truncated Stat1: interaction between $\mathrm{NH} 2$-terminal domains stabilizes binding of two dimers to tandem DNA sites. EMBO J $\underline{15}, 5616-5626$

Vinkemeier U, Moarefi I, Darnell JE, Kuriyan J (1998): Structure of the aminoterminal protein interaction domain of STAT-4. Science $\underline{279}, 1048-1052$

Waksman G, Kominos D, Robertson SC, Pant N, Baltimore D, Birge RB, Cowburn D, Hanafusa H, Mayer BJ, Overduin M, Resh MD, Rios CB, Silverman L, Kuriyan J (1992): Crystal structure of the phosphotyrosine recognition domain $\mathrm{SH} 2$ of $\mathrm{v}$-src complexed with tyrosine-phosphorylated peptides. Nature $\underline{358}, 646-653$

Wegenka UM, Buschmann J, Lutticken C, Heinrich PC, Horn F (1993): Acutephase response factor, a nuclear factor binding to acute-phase response elements, is rapidly activated by interleukin-6 at the posttranslational level. Mol Cell Biol $\underline{13}, 276-$ 288

Weis K (1998): Importins and exportins: how to get in and out of the nucleus. Trends Biochem Sci 23, 185-189 
Wen Z, Darnell JE (1997): Mapping of Stat3 serine phosphorylation to a single residue (727) and evidence that serine phosphorylation has no influence on DNA binding of Stat1 and Stat3. Nucleic Acids Res $\underline{25}, 2062-2067$

Wen Z, Zhong Z, Darnell JE (1995): Maximal activation of transcription by Stat 1 and Stat3 requires both tyrosine and serine phosphorylation. Cell $\underline{82}, 241-250$

Wenta N, Strauss H, Meyer S, Vinkemeier U (2008): Tyrosine phosphorylation regulates the partitioning of STAT1 between different dimer conformations. Proc Natl Acad Sci U S A 105, 9238-9243

Wurster AL, Tanaka T, Grusby MJ (2000): The biology of Stat4 and Stat6. Oncogene $\underline{19}, 2577-2584$

Xu X, Sun YL, Hoey T (1996): Cooperative DNA binding and sequence-selective recognition conferred by the STAT amino-terminal domain. Science $\underline{273}, 794-797$

Yan R, Small S, Desplan C, Dearolf CR, Darnell JE (1996): Identification of a Stat gene that functions in Drosophila development. Cell $\underline{84}, 421-430$

Yang E, Wen Z, Haspel RL, Zhang JJ, Darnell JE (1999): The linker domain of Stat1 is required for gamma interferon-driven transcription. Mol Cell Biol $\underline{19}, 5106-$ 5112

Zeng R, Aoki Y, Yoshida M, Arai K, Watanabe S (2002): Stat5B shuttles between cytoplasm and nucleus in a cytokine-dependent and -independent manner. J Immunol $\underline{168}, 4567-4575$

Zhang X, Blenis J, Li HC, Schindler C, Chen-Kiang S (1995): Requirement of serine phosphorylation for formation of STAT-promoter complexes. Science 267, 19901994 
Zhang JJ, Vinkemeier U, Gu W, Chakravarti D, Horvath CM, Darnell JE (1996): Two contact regions between Stat1 and CBP/p300 in interferon gamma signaling. Proc Natl Acad Sci U S A $\underline{93}, 15092-15096$

Zhang JJ, Zhao Y, Chait BT, Lathem WW, Ritzi M, Knippers R, Darnell JE (1998): Ser727-dependent recruitment of MCM5 by Stat1alpha in IFN-gamma-induced transcriptional activation. EMBO J $\underline{17}$, 6963-6971

Zhang T, Kee WH, Seow KT, Fung W, Cao X (2000): The coiled-coil domain of Stat3 is essential for its $\mathrm{SH} 2$ domain-mediated receptor binding and subsequent activation induced by epidermal growth factor and interleukin-6. Mol Cell Biol $\underline{20}$, 71327139

Zhang T, Seow KT, Ong CT, Cao X (2002): Interdomain interaction of Stat3 Regulates Its Src Homology 2 Domain-mediated Receptor Binding Activity. J Biol Chem $\underline{277}, 17556-17563$

Zhong M, Henriksen MA, Takeuchi K, Schaefer O, Liu B, ten Hoeve J, Ren Z, Mao X, Chen X, Shuai K, Darnell JE (2005): Implications of an antiparallel dimeric structure of nonphosphorylated STAT1 for the activation-inactivation cycle. Proc Natl Acad Sci U S A 102, 3966-3971 


\section{Danksagung}

Der erste und größte Dank gilt meinem Doktorvater Prof. Dr. Dr. Dr. Thomas Meyer. Er hat mir ein hochinteressantes Dissertationsthema zur Verfügung gestellt und mich in die Thematik eingearbeitet. Dabei hat er sich nicht nur stets für meine Forschungsergebnisse und Fragen interessiert, es war inm ebenfalls wichtig, das Grundlagenwissen und die Arbeit mit wissenschaftlichen Materialien durch kleine Seminare zu unterstützen. Die Arbeit konnte vor allem durch seine motivierenden Anregungen und die immerwährende Diskussionsbereitschaft zu einem erfolgreichen Ende gebracht werden. Ich bedanke mich ausdrücklich für das mir entgegengebrachte Vertrauen vor allem, was die Bereitstellung der sehr hochwertigen und sensiblen Materialien und Gerätschaften anbetrifft und für die Übernahme des Erstgutachtens.

Des Weiteren bedanke ich mich bei Herrn Prof. Dr. Christoph Herrmann-Lingen für die wissenschaftliche Unterstützung und sein Interesse an meiner Arbeit.

Ein weiterer großer Dank geht an Frau Dr. Julia Staab. Sie hat sich stets für meine Arbeit eingesetzt und mich tatkräftig unterstützt. Vor allem verdanke ich die Ergebnisse aus der RT-PCR ihrer Unterstützung und konstruktiven Hilfe. Nicht nur damit hat sie zu einem guten Gelingen meiner Arbeit beigetragen.

Besonders möchte ich mich auch bei den wissenschaftlichen Mitarbeiterinnen des Labors bedanken. Frau Anke Gregus und Frau Heike Hühn haben es mir durch eine gründliche Einarbeitung in alle Labortätigkeiten ermöglicht, selbständig an meinen Versuchen arbeiten zu können. Bei den Experimenten waren sie stets äußerst hilfsbereit und standen mir mit guten Ratschägen zur Seite.

Bei den Arbeitsgruppen der Abteilung Neurodegeneration, Neuroimmunologie / IMSF und Neurophysiologie bedanke ich mich zutiefst für die Möglichkeit, die Laborgeräte nutzen zu dürfen und für die vielen wissenschaftlichen Anregungen. 